\title{
Integrating Wind Turbines into the Orcas Island Distribution System
}

\author{
Henry W. Zaininger \\ Zaininger Engineering Company \\ Roseville, California
}

DISTRIBUTION OF THS DOCUMEENT IS UNLANTED

NREL Technical Monitor: Brian Parsons

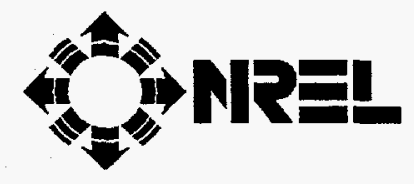

National Renewable Energy Laboratory 1617 Cole Boulevard

Golden, Colorado 80401-3393

A national laboratory of the U.S. Department of Energy Managed by Midwest Research Institute for the U.S. Department of Energy under contract No. DE-AC36-83CH10093

Work performed under Subcontract No. TAT-6-16476-01

September 1998 


\section{NOTICE}

This report was prepared as an account of work sponsored by an agency of the United States government. Neither the United States government nor any agency thereof, nor any of their employees, makes any warranty, express or implied, or assumes any legal liability or responsibility for the accuracy, completeness, or usefulness of any information, apparatus, product, or process disclosed, or represents that its use would not infringe privately owned rights. Reference herein to any specific commercial product, process, or service by trade name, trademark, manufacturer, or otherwise does not necessarily constitute or imply its endorsement, recommendation, or favoring by the United States government or any agency thereof. The views and opinions of authors expressed herein do not necessarily state or reflect those of the United States government or any agency thereof.

Available to DOE and DOE contractors from:

Office of Scientific and Technical Information (OSTI)

P.O. Box 62

Oak Ridge, TN 37831

Prices available by calling (423) 576-8401

Available to the public from:

National Technical Information Service (NTIS)

U.S. Department of Commerce

5285 Port Royal Road

Springfield, VA 22161

(703) $487-4650$ 


\section{Foreword}

This project was a follow-on to investigations sponsored by Oak Ridge National Laboratory and Sandia National Laboratories into alternatives to upgrading an undersea electric transmission cable to supply additional power to Orcas Island, Washington. Previous work examined wind power and battery energy storage as possibly economic. However, further measurement of the wind resource and accompanying analysis was needed to strengthen the conclusions. This work illustrates the value of wind power applications where the electric demand and wind resource have a strong time coincidence. In addition to fuel displacement (energy value), there are reliability (capacity value) and upgrade deferment (distributed value) benefits. This analysis supports the overall U.S. Department of Energy Wind Energy Program by providing a concrete illustration of wind energy's benefits beyond fuel saving. The analysis techniques can be used to evaluate other potential distributed applications, furthering the program goal of deployment of appropriate utility applications of the technology.

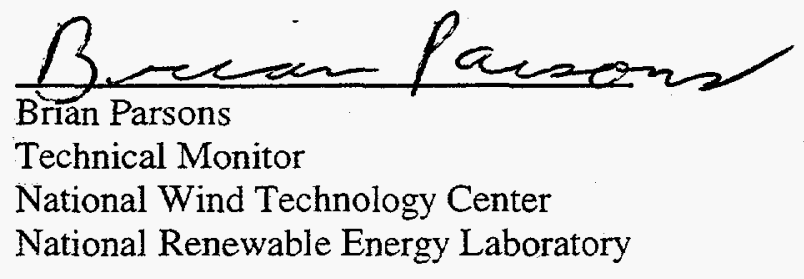




\section{Preface}

This research effort consists of two years of wind data collection and analysis to investigate the possibility of strategically locating a megawatt (MW)-scale wind farm near the end of an Orcas Power \& Light Company (OPALCO) 25-kilovolt (kV) distribution circuit to defer the need to upgrade the line to $69 \mathrm{kV}$. The results of this study support the results of previous work in which another year of wind data collection and analysis was performed. Both this study and the previous study show that adding a MWscale wind farm at the Mt. Constitution site is a feasible alternative to upgrading the OPALCO 25-kV distribution circuit to $69 \mathrm{kV}$.

The initial portion of this research was sponsored by Oak Ridge National Laboratory (ORNL), and the project was extended and sponsored by the National Renewable Energy Laboratory (NREL). In particular, the author wishes to thank P. R. (Randy) Barnes of ORNL and Brian Parsons of NREL for their support and guidance in this effort.

This project could not have been accomplished without the assistance and close participation of OPALCO. The utility data, wind data collection assistance, and suggestions provided by Douglas Bechtel and Terry Turner of OPALCO are gratefully acknowledged. 


\section{Abstract}

Strategically located "distributed applications," such as wind farms, can defer distribution system facility upgrades, increase reliability, and reduce substation stress, as well as supply other site-specific benefits. These location-specific distributed benefits are in addition to the energy value of the power delivered and potential capacity value. However, installation on weak rural distribution lines may have negative impacts as well.

As part of the investigation of this concept, this study as well as a previous study, have investigated the use of wind turbines and battery storage systems to defer Orcas Power and Light Company (OPALCO) 25-kilovolt (kV) distribution circuit upgrades. Wind data have been collected for three years through the 1994-1995, 1995-1996, and 1996-1997 winter peak seasons at the Mt. Constitution site to establish wind-speed correlation with projected extreme peak-load conditions. In addition, examples of highresolution one-minute and ten-minute wind speed data were also gathered and analyzed to determine potential voltage fluctuations resulting from variations in wind farm output on the OPALCO distribution system.

The results of this work indicate that adding a megawatt (MW)-scale wind farm at the Mt. Constitution site is a feasible alternative to upgrading the $25-\mathrm{kV}$ Lopez-Eastsound circuit to $69 \mathrm{kV}$ in 2000 . Expected frequent minute-to-minute voltage fluctuations resulting from wind variability would be above acceptable voltage flicker levels. Three methods of mitigating these voltage fluctuations were investigated which resulted in reducing voltage flicker levels to acceptable levels. Thus, voltage flicker problems are not expected to be a "show stopper" for distributed rural distribution system, wind farm installations. 


\section{Executive Summary}

\section{Introduction}

Wind turbines can, under certain conditions, have high distribution system support value to utilities if installed on stressed distribution systems, or in areas where distribution facility upgrades are anticipated. Strategically located "distributed applications" can defer line or transformer upgrades, increase reliability, and reduce substation stress, as well as supply other site-specific benefits. These location-specific distributed benefits also include the energy value of the power delivered and potential capacity value. However, installation on weak rural distribution lines may have negative impacts, as well.

As part of the investigation of this concept Oak Ridge National Laboratory (ORNL) and Sandia National Laboratories have investigated the use of wind turbines and battery storage systems to deferOrcas Power and Light Company (OPALCO) 25 kilovolt (kV) distribution circuit upgrades. The results of this work indicated that adding a megawatt (MW)-scale wind farm at the Mt. Constitution site is an economic alternative to upgrading the $25-\mathrm{kV}$ Lopez-Eastsound circuit to $69 \mathrm{kV}$ in 2000.

In this previous study there was good correlation between high winds and annual distribution circuit peak load. However, data were gathered for one year, and extreme design peak-load conditions did not occur during this one-year period. Hence, in this study, the National Renewable Energy Laboratory and ORNL have extended the wind data collection and analysis of the integration of wind turbines in the OPALCO distribution system. Additional wind data have been collected for two years through the 1995-1996 and 1996-1997 winter peak seasons at the Mt. Constitution site to establish wind speed correlation with projected extreme peak-load conditions.

In addition, system operational impacts and interactions occur on a time scale of less than one hour. One of these occurrences that is of concern to utilities is voltage fluctuations resulting from the inherent variability of the wind resource and wind turbine output. Thus, as part of this study, example highresolution one-minute and ten-minute wind speed data were also gathered and analyzed to determine potential voltage fluctuations resulting from variations in wind farm output on the OPALCO distribution system.

\section{Results and Conclusions}

The results of this study support the results of the previous work. Adding a MW-scale wind farm at the Mt. Constitution site is a feasible alternative to upgrading the $25-\mathrm{kVLopez}$-Eastsound circuit to $69 \mathrm{kV}$ in 2000. Wind data collection results in this study and in the previous study indicate that Mt. Constitution is a good wind site. Assuming the measured winds at the instrument height of $163 \mathrm{ft} .(49.6 \mathrm{~m})$, the resulting annual capacity factor for a wind farm installed at this location would have been $21.2 \%$ in 1994-1995, $20.5 \%$ in 1995-1996, and $17.5 \%$ in 1996-1997. Measured wind data indicated good correlation between high winds and projected annual Eastsound peak load over the three-year measurement period. A wind speed of approximately $22 \mathrm{mph}$ was measured during the actual annual 1994-1995 winter peak load, 20 mph during the actual annual 1995-1996 winter peak load, and 16 mph during the actual annual 19961997 winter peak load.

Projected annual extreme peak-loading conditions on the OPALCO system did occur during the 19951996 winter peak season. During this extreme peak-loading condition, there was good correlation between low temperature and high wind. During this design peak-loading condition, a 1.5-MW wind farm would have reduced the annual Eastsound peak load by $552 \mathrm{~kW}$. 
Sample high-resolution wind data were collected during this study during normal everyday winds. These data indicate that minute-to-minute winds vary significantly about the mean hourly winds. Calculations showed that these wind variations can cause frequent large minute-to-minute wind farm output fluctuations, ranging up to over $1000 \mathrm{~kW}$ for a $1.5-\mathrm{MW}$ wind farm installed at the $\mathrm{Mt}$. Constitution wind site.

A preliminary assessment of potential power flows from the wind farm toEastsound substation, using an existing $12.47-\mathrm{kV}$ distribution circuit, was performed as part of this study. These calculations were made to determine the magnitude of expected local distribution system voltage fluctuations associated with these large minute-to-minute wind farm output variations, and expected var performance. These initial calculations showed that expected frequent minute-to-minute voltage fluctuations would be above acceptable voltage flicker levels.

Three alternative methods of mitigating voltage flicker problems were evaluated in this study. First, a portion of the distribution circuit containing small conductors could bereconductored. Second, variablespeed wind generators, capable of providing a large variable range of vars, could be operated in a voltage regulation mode. Third, a power enhancement and delivery system could be employed. All three methods resulted in reducing voltage flicker levels to acceptable levels. Thus, voltage flicker problems are an important consideration but are not expected to be a "show stopper" for rural distribution system, wind farm installations. However, a more detailed study is required to determine the best way to reduce these voltage problems for this application.

It is expected that similar results will occur when adding a MW-scale wind farm to rural distribution systems for many other utilities. First, for many winter peaking utilities throughout the northern United States, distribution circuit upgrades are likely to be based on extreme annual winter peak design loads, which occur during coincident low-temperature and high-wind ambient conditions. Second, rural distribution systems on many other utilities are also expected to contain long distribution circuits with small conductors. MW-scale wind farm installations at the end of these rural feeders will also need to consider minute-to-minute voltage fluctuation performance, and means to mitigate potential voltage problems. 


\section{Table of Contents}

Forward

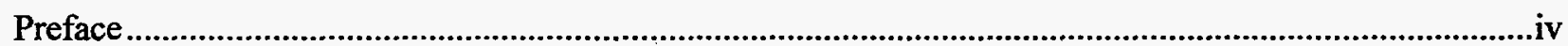

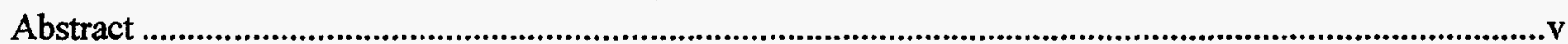

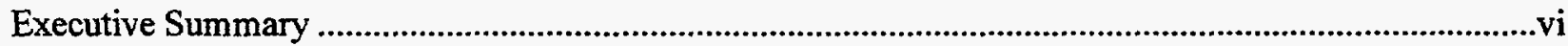

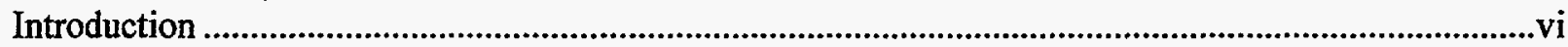

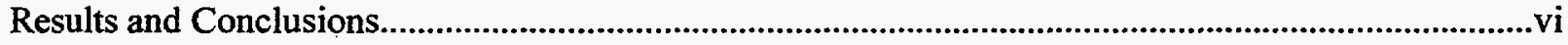

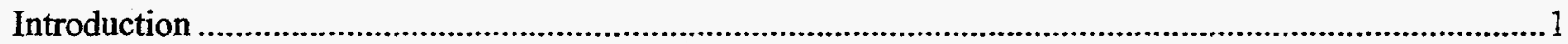

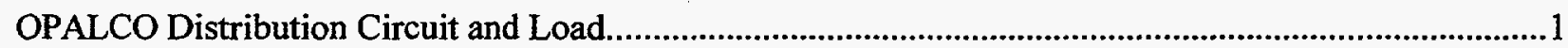

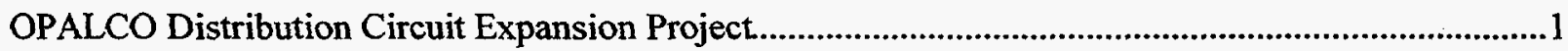

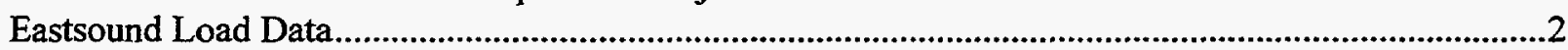

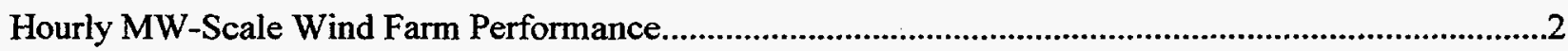

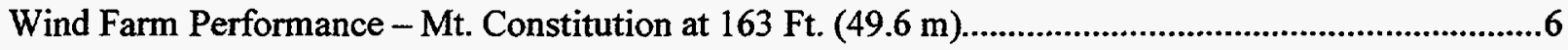

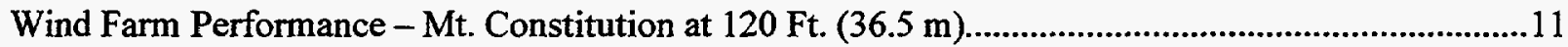

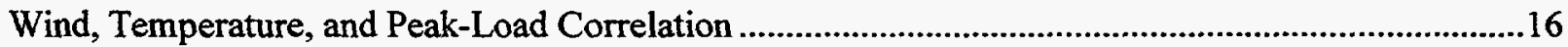

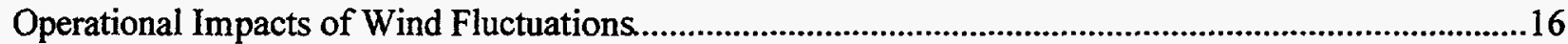

Wind Measurements and Expected Wind Farm Output Fluctuations..................................................19

Potential Distribution System Voltage Fluctuation Impacts..........................................................28

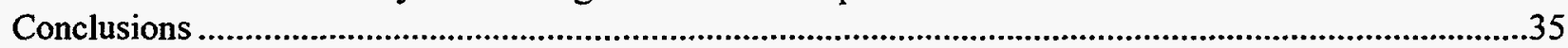

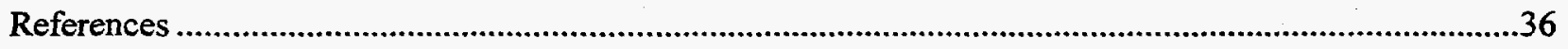

APPENDIX A - Hourly Eastsound Loads During 1995-1996 and 1996-1997 Winter

Peak Seasons

APPENDIX B - Hourly Wind and MW-Scale Wind Plant Performance - Mt.

Constitution $163 \mathrm{Ft}$. $(49.6 \mathrm{~m})$.

APPENDIX C - Hourly Wind and MW-Scale Wind Plant Performance - Mt.

Constitution $120 \mathrm{Ft}$. $(36.5 \mathrm{~m})$. 


\section{List of Figures}

Figure 1.

Figure 2.

Figure 3.

Figure 4.

Figure 5.

Figure 6.

Figure 7.

Figure 8.

Figure 9.

Figure 10.

Figure 11.

Figure 12.

Figure 13.

Figure 14.

Figure 15.

Figure 16.

Figure 17.

Figure 18.

Figure 19.

Figure 20.

Figure 21 .

Figure 22.

Figure 23 .

Figure 24 .

Figure A.1. Figure A.2. Figure A.3. Figure A. 4. Figure A.5. Figure A.6. Figure A.7. Figure A.8.

Figure B.1. Figure B.2.

Figure B.3.
Eastsound monthly peak loads 3

Winter peak-day load shapes for 1995-1996 and 1996-1997 seasons. 4

Zond Z-46 wind turbine power curve .. 5

Average monthly wind speed throughout the study period. 7 Wind farm impact on Eastsound load during 1995-1996 winter peak day, January $30,1996-163 \mathrm{ft}$. (49.6 m) winds . .8

Wind farm impact on Eastsound load during 1996-1997 winter peak day, December 28, 1996-163 ft. (4.9.6 m) winds

Average monthly wind speed throughout the study period -

$163 \mathrm{ft} .(49.6 \mathrm{~m})$ winds 12

Wind farm impact on Eastsound load during 1995-1996 winter peak day, January $30,1996-120 \mathrm{ft}$. (36.5 m) winds 13

Wind farm impact on Eastsound load during 1996-1997 winter peak day, December 28, 1996-120ft. (36.5 m) winds 15

Hourly Orcas Island temperature in January 1996.................................................. 17

Hourly Orcas Island temperature in December 1996................................................. 18

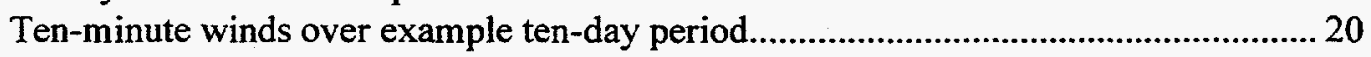

Ten-minute winds during eight hour period in Day 6 .............................................. 21

One-minute winds over example 23-hour period........................................................ 22

Corresponding hourly winds over 23-hour period ....................................................... 23

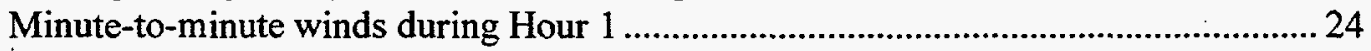

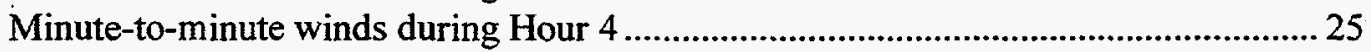

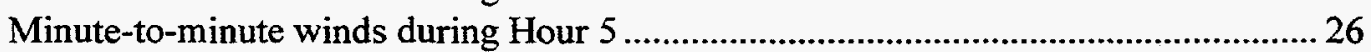

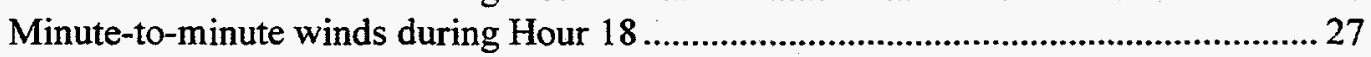

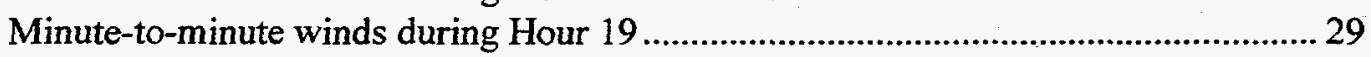

One-line diagram of $12.47-\mathrm{kV}$ distribution circuit connecting wind farm to Eastsound substation. 30

Range of voltage fluctuations on existing distribution circuit..................................... 31

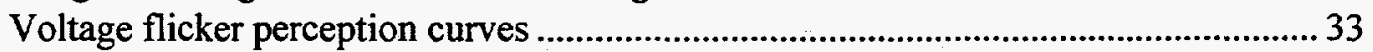

Range of voltage fluctuations with \#6 AWG replaced with 4/0

ACSR

Hourly Eastsound load - November 1995

A-2

Hourly Eastsound load - December 1995

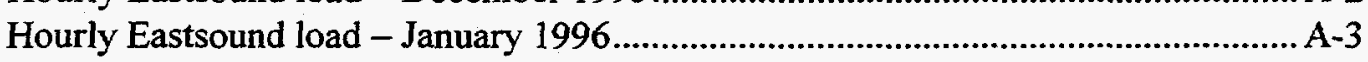

Hourly Eastsound load - February 1996............................................................... A-3

Hourly Eastsound load - November 1996 ........................................................... A-4

Hourly Eastsound load - December 1996 ............................................................ A-4

Hourly Eastsound load - January 1997 ................................................................. A-5

Hourly Eastsound load - February 1997............................................................. A-5

Hourly wind speed at $163 \mathrm{ft} .(49.6 \mathrm{~m})$ in November 1995

Hourly 1.5 MW wind farm performance in November 1995-163' ft. $(49.6 \mathrm{~m})$ winds

Hourly wind speed at $163 \mathrm{ft} .(49.6 \mathrm{~m})$ in December 1995.

B-3 
Figure B.4. Hourly 1.5 MW wind farm performance in December $1995-163 \mathrm{ft} .(49.6 \mathrm{~m})$ winds

Figure B.5.

Hourly wind speed at $163 \mathrm{ft} .(49.6 \mathrm{~m})$ in January 1996

Figure B.6. Hourly 1.5 MW wind farm performance in January 1996-163 ft. (49.6 m) winds.. B-4

Figure B.7. Hourly wind speed at $163 \mathrm{ft} .(49.6 \mathrm{~m})$ in February 1996

Figure B.8. Hourly 1.5 MW wind farm performance in February $1996-163 \mathrm{ft} .(49.6 \mathrm{~m})$ winds B-5

Figure B.9. Hourly wind speed at $163 \mathrm{ft} .(49.6 \mathrm{~m})$ in November 1996

Figure B.10. Hourly 1.5 MW wind farm performance in November $1996-163 \mathrm{ft}$. (49.6 m) winds

Figure B.11. Hourly wind speed at $163 \mathrm{ft}$. $(49.6 \mathrm{~m})$ in December 1996 .

Figure B.12.

Hourly 1.5 MW wind farm performance in December 1996-163 ft. $(49.6 \mathrm{~m})$ winds

Figure B.13. Hourly wind speed at $163 \mathrm{ft}$. (49.6 m) in January 1997

Figure B.14. Hourly $1.5 \mathrm{MW}$ wind farm performance in January $1997-163 \mathrm{ft} .(49.6 \mathrm{~m})$ winds... B-8

Figure B.15. Hourly wind speed at $163 \mathrm{ft}$. (49.6 m) in February 1997

Figure B.16. Hourly 1.5 MW wind farm performance in February 1997-163 ft. (49.6 m) winds B-9

Figure C.1. Hourly wind speed at $120 \mathrm{ft} .(36.5 \mathrm{~m})$ in November 1995 $\mathrm{C}-2$

Figure C.2.

Hourly

Figure C.3.

\section{winds}

Figure C.4.

Figure C.5. Hourly 1.5 MW wind farm performance in December 1995-120 ft. $(36.5 \mathrm{~m})$ winds

Figure C.6.

Hourly wind speed at $120 \mathrm{ft}$. $(36.5 \mathrm{~m})$ in January 1996.

Figure C.7.

Figure C.8.

Hourly wind speed at $120 \mathrm{ft}$. (36.5 m) in February 1996.

Hourly 1.5 MW wind farm performance in February 1996-120 ft. (36.5 m) winds

Figure C.9. Hourly wind speed at $120 \mathrm{ft}$. (36.5 m) in November 1996

Figure C.10.

wourly

Figure C.11.

Hourly wind speed at $120 \mathrm{ft}$. $(36.5 \mathrm{~m})$ in December 1996.

Figure C.12.

Hourly 1.5 MW wind farm performance in December 1996-120 ft. (36.5 m) winds

Figure C.13.

Hourly wind speed at $120 \mathrm{ft}$. (36.5 m) in January 1997.

Figure C.14.

Figure C.15.

Hourly 1.5 MW wind farm performance in January $1997-120 \mathrm{ft} .(36.5 \mathrm{~m})$ winds.. C-8

Hourly wind speed at $120 \mathrm{ft}$. (36.5 m) in February 1997.

Figure C.16.

Hourly 1.5 MW wind farm performance in February 1997-120 ft. (36.5 m) winds C-9 


\section{List of Tables}

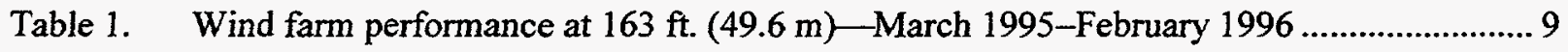

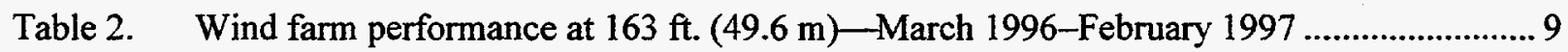

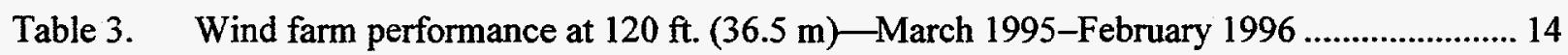

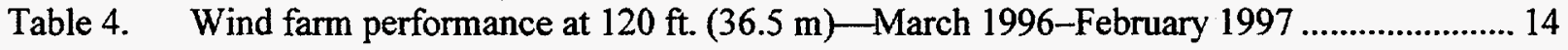




\section{Introduction}

Wind turbines can, under certain conditions, have high distribution system support value to utilities if installed on stressed distribution systems or in areas where distribution facility upgrades are anticipated. Strategically located "distributed applications" can defer line or transformer upgrades, increase reliability, and reduce substation stress, as well as supply other site-specific benefits. These location-specific distributed benefits also include the energy value of the power delivered and potential capacity value. However, installation on weak rural distribution lines may have negative impacts, as well.

As part of the investigation of this concept Oak Ridge National Laboratory (ORNL) and Sandia National Laboratories (SNL) have investigated the use of wind turbines and battery storage systems to defer Orcas Power and Light Company (OPALCO) 25-kilovolt (kV) distribution circuit upgrades. This past work 1-3 included both technical and economic evaluations. The results of this work indicated that adding a megawatt (MW)-scale wind farm at the Mt. Constitution site is an economic alternative to upgrading the $25-\mathrm{kV}$ Lopez-Eastsound circuit to $69 \mathrm{kV}$ in 2000 . The results of this previous assessment were based on gathering one year of hourly wind measurements through the 1994-1995 winter peak season.

In this previous study there was good correlation between high winds and annual distribution circuit peak load. However, extreme design peak-load conditions did not occur during this one-year period. Hence, in this study, the National Renewable Energy Laboratory (NREL) and ORNL have extended the wind data collection and analysis of the integration of wind turbines in the OPALCO distribution system. Additional wind data have been collected for two years through the 1995-1996 and 1996-1997 winter peak seasons at the Mt. Constitution site to establish wind speed correlation with projected extreme peak load conditions.

In addition, system operational impacts and interactions occur on a time scale of less than one hour. One of these occurrences that is of concern to utilities is voltage fluctuations resulting from the inherent variability of the wind resource and wind turbine output. Thus, as part of this study, example highresolution one-minute and ten-minute wind speed data were also gathered. These data were then analyzed to determine potential voltage fluctuations resulting from variations in wind farm output on the OPALCO distribution system.

First, the OPALCO distribution circuit expansion project and hourly load data atEastsound are described. Second, MW-scale wind farm performance and peak load correlation results are presented. Third, the expected operational impacts (voltage fluctuations) on the distribution circuit resulting from minute-tominute wind farm output variability are presented, and then conclusions and recommendations are presented.

\section{OPALCO Distribution Circuit and Load}

\section{OPALCO Distribution Circuit Expansion Project}

OPALCO serves the San Juan Islands in Puget Sound, north of Seattle, Washington. OPALCO power is supplied by Bonneville Power Administration (BPA). The BPA interconnection point is on Lopez Island.

The distribution circuit in question consists of $25 \mathrm{kVs}$ that extends from the BPA interconnection point on Lopez Island to Shaw Island, and then on to Orcas Island, using both overhead and under-water construction. The far end of the line is located at Eastsound, where OPALCO has a 1-MW diesel plant. 
As described in the previous study, 3 OPALCO is currently experiencing serious voltage problems on this $25-\mathrm{kV}$ circuit. This $25-\mathrm{kV}$ circuit is currently voltage-limited, and this voltage limit is determined by the magnitude of the annual peak load at the Eastsound substation. As discussed with OPALCO personnel and described previously, this voltage-limited 25-kV Lopez-to-Eastsound distribution circuit growth, which causes the voltage problems at Eastsound, will be upgraded to $69 \mathrm{kV}$ because of the projected peak load growth which causes the voltage problems at Eastsound. OPALCO is currently implementing a load management plan to reduce Eastsound peak loads. This load management plan will defer the distribution circuit upgrade to $69 \mathrm{kV}$ until the 2000-2001 winter season.

\section{Eastsound Load Data}

Figure 1 presents the (integrated hourly) monthly peak loads from March 1995 through February 1997. These data show that OPALCO peaks during the winter. Integrated hourly, Eastsound loads are presented monthly in Appendix A for the 1995-1996 and 1996-1997 winter peak seasons (November through February). During this two-year study period, the integrated hourly Eastsound peak of 8514 kilowatt (kW) occurred on January 30, 1996, between 8 a.m. and 9 a.m. Figure 2 shows the January 30, 1996 peak day-load shape and the peak day-load shape for the 1996-1997 winter season, which occurred on December 28, 1996. Review of Figures 1 and 2, including the Eastsound load plots in Appendix A show that the Eastsound daily peak load only exceeded $8000 \mathrm{~kW}$ during three days over the two-year period-the peak day on January 30, 1996, January 29, 1996, and December 28, 1996. For the rest of the two-year period, the hourly Eastsound loads were significantly less than the annual peak loads.

\section{Hourly MW-Scale Wind Farm Performance}

In this study, detailed hourly wind data have been collected near the top of Mt. Constitution on Orcas Island, near Eastsound, to determine the relative site-specific impacts of a MW-scale wind farm on the Lopez-Eastsound distribution circuit peak loads, and determine expected monthly and annual wind farm energy production. Mt. Constitution was determined to be a good site in the previous study. 3 In this study, the wind farm performance over the two years will be compared with the performance over the first year described in the previous report.

In this study the MW-scale wind farm performance was determined assuming two $750 \mathrm{~kW}$ Zond Z-46 wind turbines were installed, each with the power curve shown in Figure 3. These variable-speed wind turbines cut in at low-wind speeds and attain rated output when the winds exceed approximately $27 \mathrm{mph}$. Because the existing 25-kV Lopez-Eastsound distribution circuit is voltage limited, variable-speed wind turbines like these can also provide voltage support at Eastsound by supplying vars, rather than consuming vars like some wind turbine designs using induction generators. The relative impacts on local distribution minute-to-minute voltage fluctuations will be illustrated in the next section.

The following paragraphs summarize the expected $\mathrm{MW}$-scale wind farm performance assuming the wind data was collected at elevations of $163 \mathrm{ft}$. $(49.6 \mathrm{~m})$ and $120 \mathrm{ft}$. $(36.5 \mathrm{~m})$ from March 1995 through February 1997. 


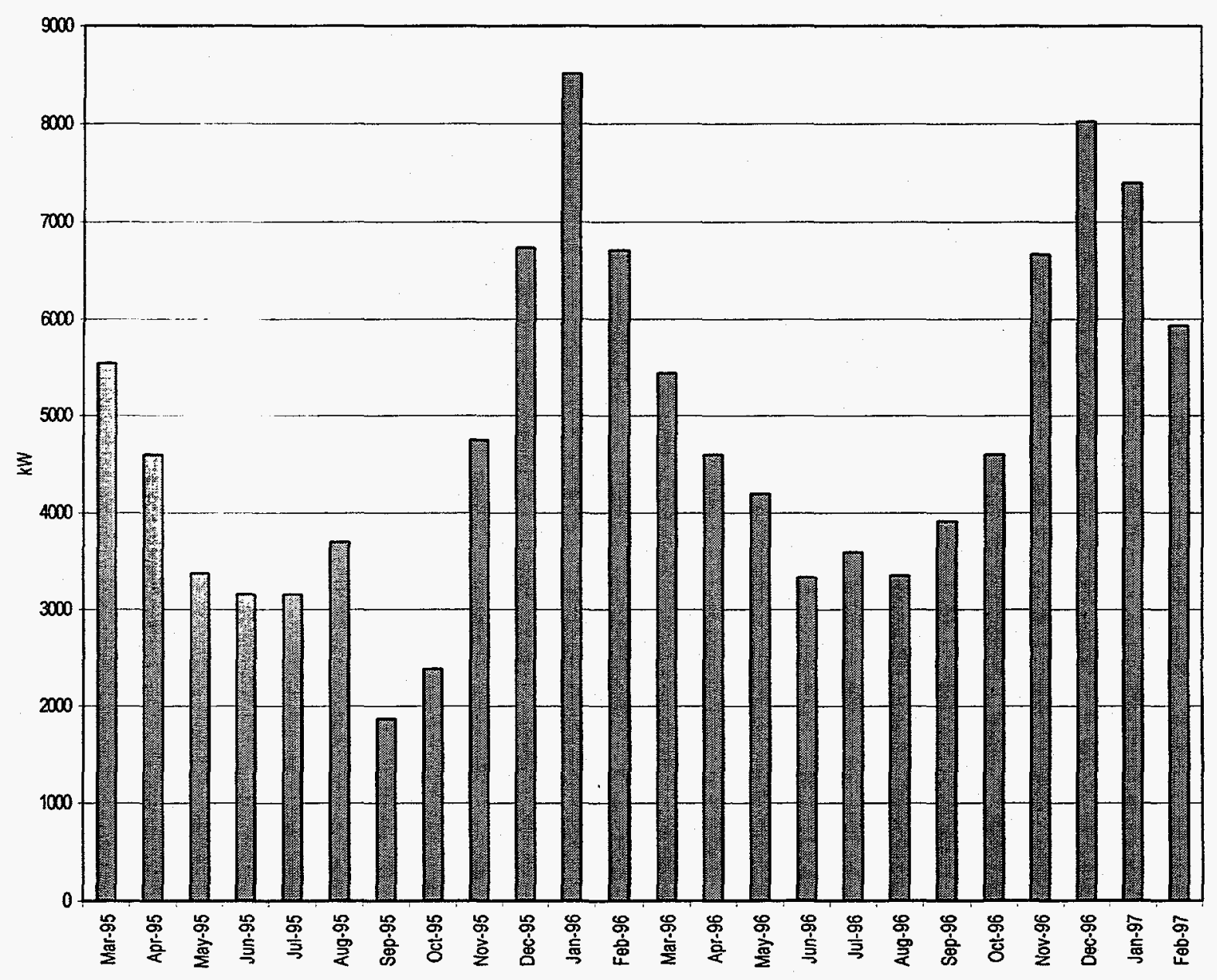

Figure 1. Eastsound monthly peak loads 


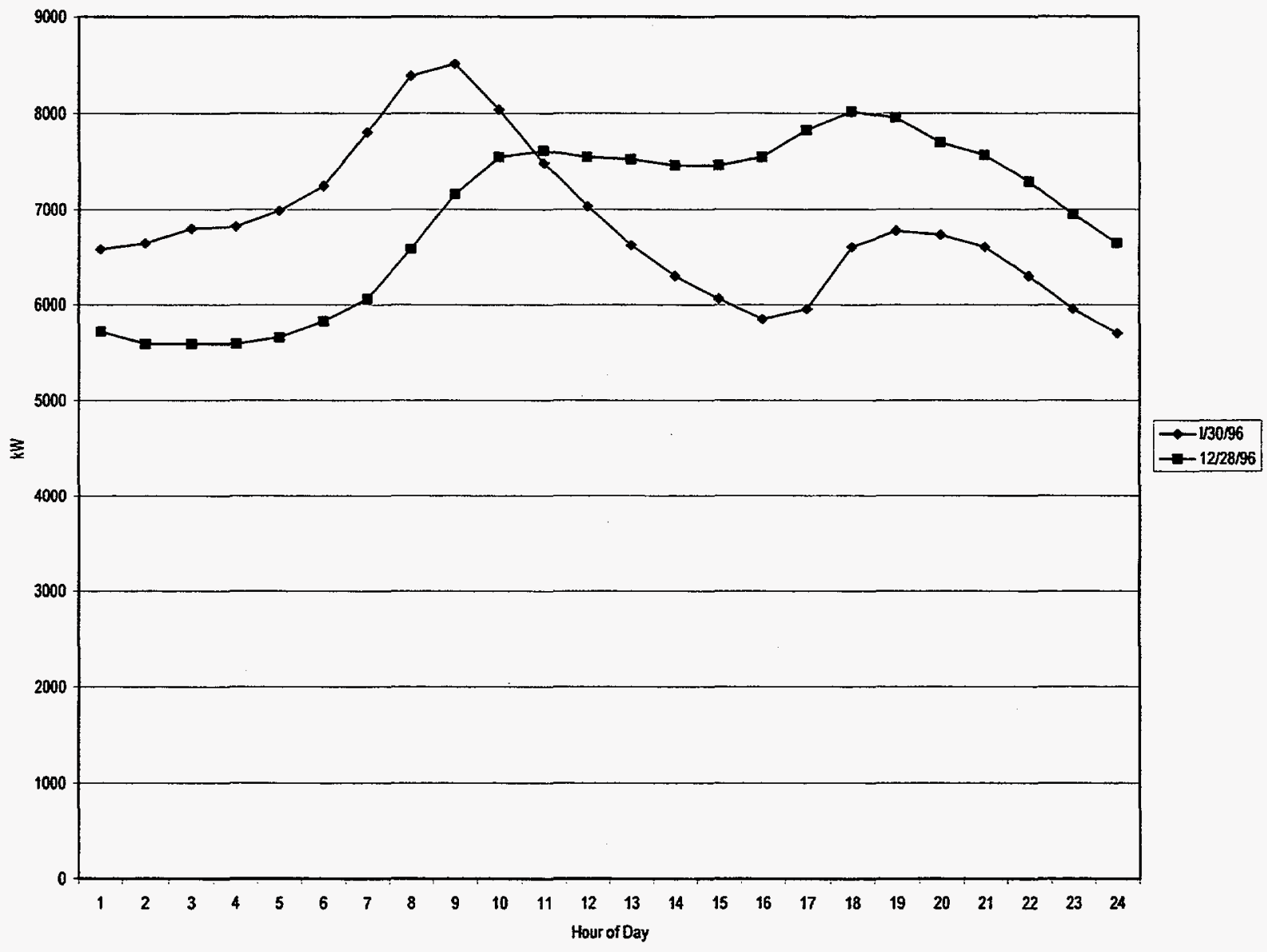

Figure 2. Winter peak day-load shapes for 1995-1996 and 1996-1997 seasons 


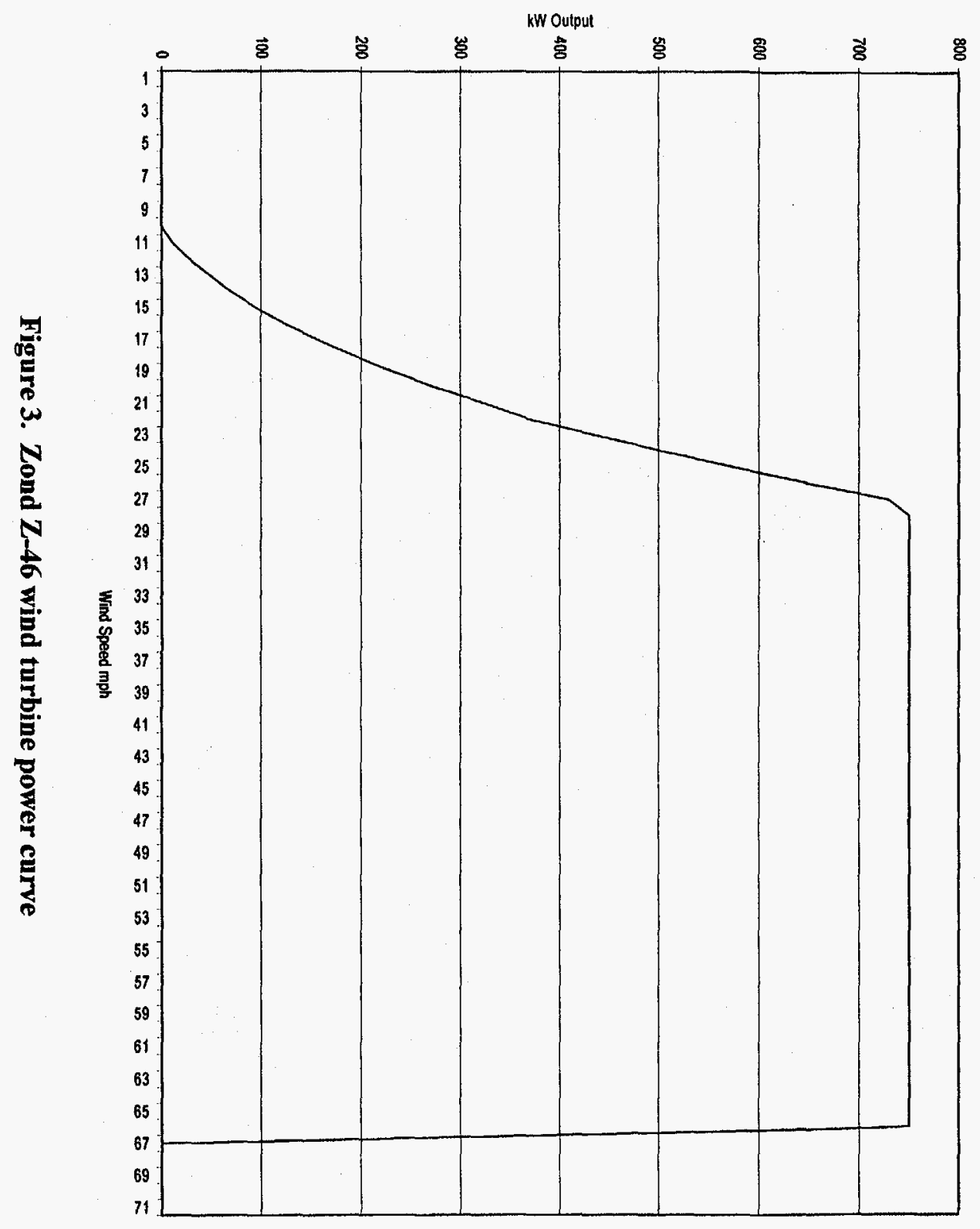




\section{Wind Farm Performance - Mt. Constitution at 163 Ft. (49.6 m)}

Hourly wind data were collected near the top of Mt. Constitution at the $163 \mathrm{ft}$. $(49.6 \mathrm{~m})$ level. At this elevation, the resulting annual average wind speed was about $12.6 \mathrm{mph}$ from March 1995 through February 1996, and $12.1 \mathrm{mph}$ from March 1996 through February 1997. Figure 4 shows the average monthly wind speed throughout the two-year period at this elevation. In the winter months, during OPALCO's peak season, the average monthly wind speed is relatively high, ranging up to over $18 \mathrm{mph}$. In the summer months, the average wind speed is low, averaging less than $10 \mathrm{mph}$.

Wind farm performance from March 1995 through February 1996 is summarized in Table 1, assuming the two $750-\mathrm{kW}$ variable-speed wind turbines, the wind power curve in Figure 3, and the hourly wind data are gathered at the Mt. Constitution site at $163 \mathrm{ft}$. $(49.6 \mathrm{~m})$. For these winds, annual wind farm energy production would be close to 2700 megawatt per hour (MWh), and the annual wind farm capacity factor would be $20.5 \%$. As discussed below, some wind data were lost in January and February. Hence, the wind farm performance would actually be higher than calculated in this study.

Figures B.1 through B.8 in Appendix B show the detailed hourly wind data collected and associated wind farm performance during OPALCO's 1995-1996 winter peak season from November 1995 through February 1996, respectively. Wind farm performance is expected to be excellent during the OPALCO winter peak season. In November and December of 1995, the winds were the highest, and the expected monthly wind farm energy production was $418 \mathrm{MWh}$ and $424 \mathrm{MWh}$ respectively, resulting in monthly capacity factors of about 38\%. In January and February of 1996, some wind data were lost (likely because of anemometer icing), reducing the calculated wind farm output significantly from January $21-$ 28 , and from February 22-25. Fortunately, the anemometers were working during the peak day, January 30. These figures also show that during the winter months, the wind farm is expected to deliver full-rated $\mathrm{kW}$ output for a significant amount of time.

Like the previous study, wind farm $\mathrm{kW}$ power output correlates with and reduces the Eastsound annual peak load during the OPALCO 1995-1996 winter peak season. Figure 5 shows the impact of the wind farm on the Eastsound hourly loads during the 1995-1996 OPALCO peak load day, January 30, 1996. The Eastsound peak load between 8 a.m. and 9 a.m. is reduced $552 \mathrm{~kW}$ by the wind farm output, resulting from winds approaching $20 \mathrm{mph}$.

Wind farm performance from March 1996 through February 1997 is summarized in Table 2, assuming the two $750-\mathrm{kW}$ variable speed wind turbines, the wind power curve in Figure 3, and the hourly wind data are gathered at the Mt. Constitution site at $163 \mathrm{ft}$. $(49.6 \mathrm{~m})$. For these winds, annual wind farm energy production would be close to $2,300 \mathrm{MWh}$, and the annual wind farm capacity factor would be $17.2 \%$. The winds for this year were not as good as the previous two years. As discussed below, some wind data were lost in December, January, and February. Hence, the wind farm performance would actually be higher than calculated in this study.

Figures B.9 through B.16 in Appendix B show the detailed hourly wind data collected and associated wind farm performance during OPALCO's 1996-1997 winter peak season from November 1996 through February 1997, respectively. Wind farm performance is still good during the OPALCO winter peak season. In November, December, and January the winds were good, and in February the winds were poor. In December there was an unusual big snowstorm that caused anemometer problems (likely because of anemometer icing), reducing the calculated wind farm output significantly from December 24 until December 27. Fortunately, the anemometers were working during the peak day, December 28. 


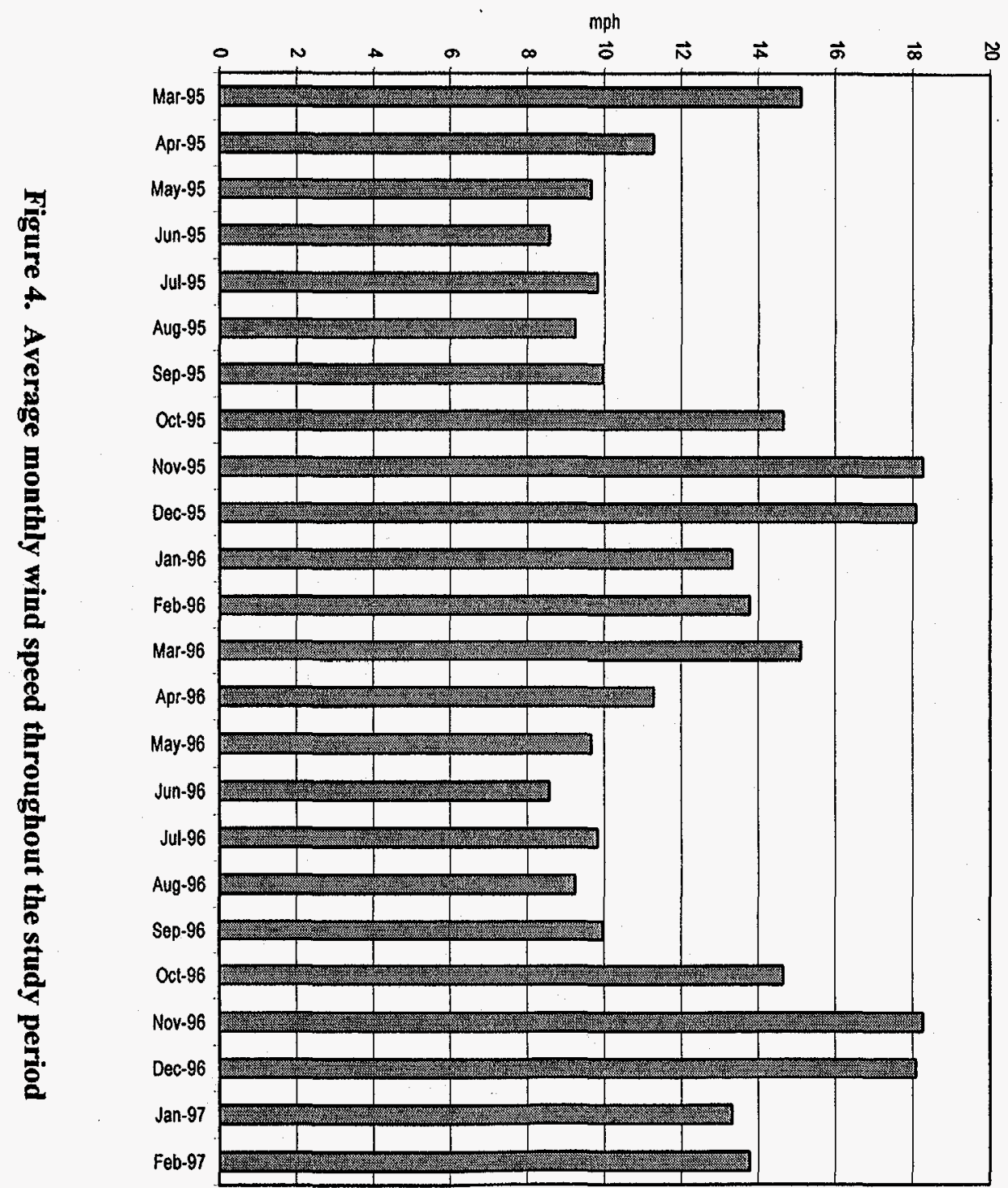




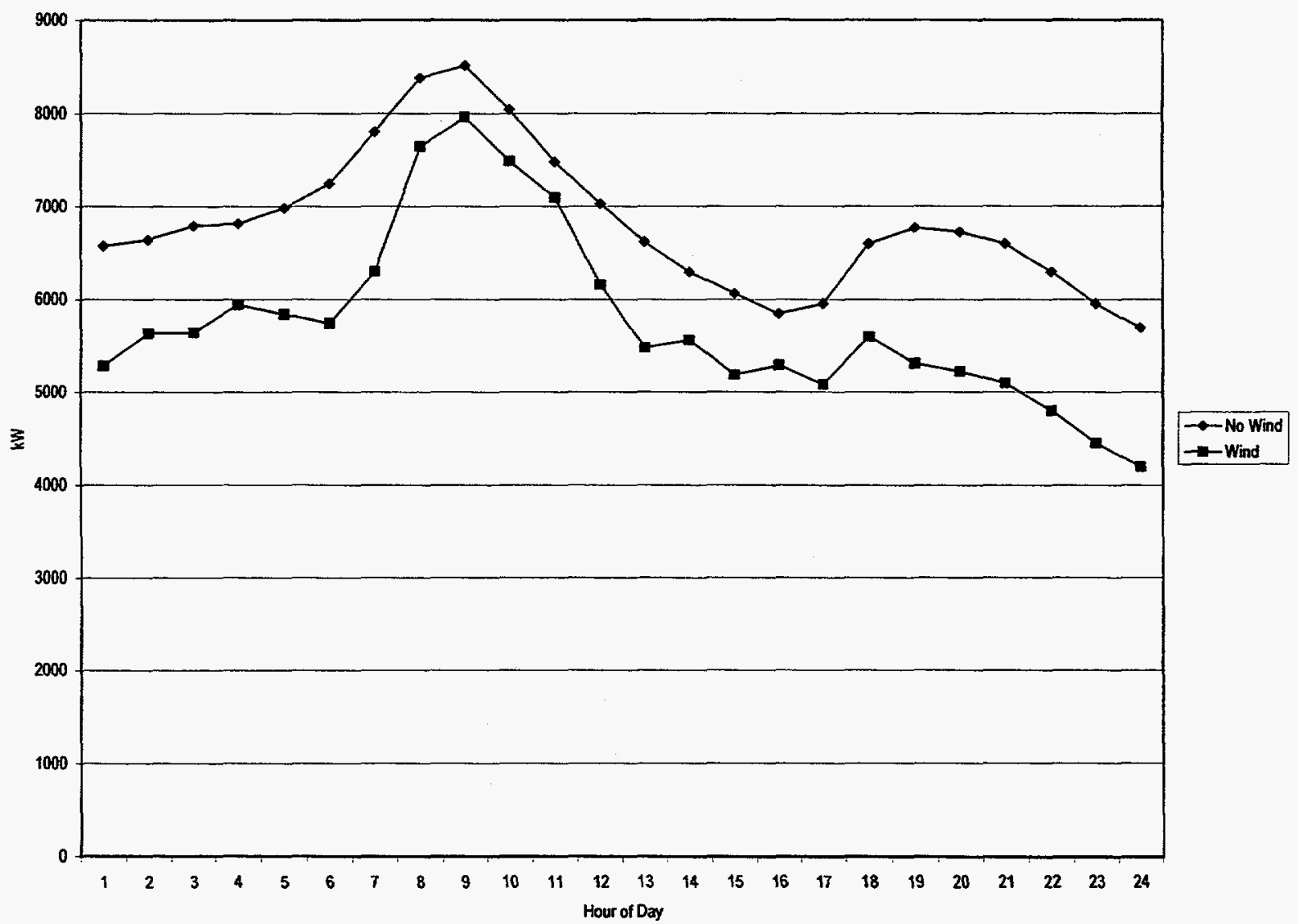

Figure 5. Wind farm impact on Eastsound load during 1995-1996 winter peak day, January 30, 1996-163 ft. (49.6 m) winds 
Table 1. Wind farm performance at 163 Ft. (49.6 m)-March 1995-February 1996

\begin{tabular}{cccc}
\hline Month & $\begin{array}{c}\text { Monthly } \\
\text { Energy } \\
\text { MWh }\end{array}$ & $\begin{array}{c}\text { Monthly } \\
\text { Capacity Factor } \\
\text { \% }\end{array}$ & $\begin{array}{c}\text { Net Peak } \\
\text { Reduction } \\
\text { kW }\end{array}$ \\
\hline Mar-95 & 344 & $30.8 \%$ & 581 \\
Apr-95 & 141 & $13.1 \%$ & 0 \\
May-95 & 87 & $7.8 \%$ & 0 \\
Jun-95 & 82 & $7.6 \%$ & 0 \\
Jul-95 & 101 & $9.0 \%$ & 43 \\
Aug-95 & 81 & $7.3 \%$ & 99 \\
Sep-95 & 98 & $9.1 \%$ & 0 \\
Oct-95 & 288 & $25.8 \%$ & 22 \\
Nov-95 & 418 & $38.7 \%$ & 0 \\
Dec-95 & 424 & $38.0 \%$ & 0 \\
Jan-96 & 336 & $30.1 \%$ & 552 \\
Feb-96 & 297 & $28.4 \%$ & 0 \\
Totals & $\mathbf{2 , 6 9 8}$ & $\mathbf{2 0 . 5 \%}$ & $\mathbf{5 5 2}$ \\
\hline
\end{tabular}

Table 2. Wind farm performance at 163 Ft. (49.6 m)-March 1996-February 1997

\begin{tabular}{cccc}
\hline Month & $\begin{array}{c}\text { Monthly } \\
\text { Energy } \\
\text { MWh }\end{array}$ & $\begin{array}{c}\text { Monthly } \\
\text { Capacity Factor } \\
\text { \% }\end{array}$ & $\begin{array}{c}\text { Net Peak } \\
\text { Reduction } \\
\text { kW }\end{array}$ \\
\hline Mar-96 & 196 & $17.5 \%$ & 172 \\
Apr-96 & 313 & $29.0 \%$ & 87 \\
May-96 & 85 & $7.7 \%$ & 0 \\
Jun-96 & 48 & $4.5 \%$ & 0 \\
Jul-96 & 101 & $9.0 \%$ & 43 \\
Aug-96 & 81 & $7.3 \%$ & 99 \\
Sep-96 & 98 & $9.1 \%$ & 0 \\
Oct-96 & 275 & $24.6 \%$ & 0 \\
Nov-96 & 295 & $27.4 \%$ & 108 \\
Dec-96 & 351 & $31.5 \%$ & 246 \\
Jan-97 & 251 & $30.2 \%$ & 0 \\
Feb-97 & 170 & $18.6 \%$ & 0 \\
Totals & $\mathbf{2 , 2 6 6}$ & $\mathbf{1 7 . 2 \%}$ & $\mathbf{2 4 6}$ \\
\hline
\end{tabular}

From January 24 through February 3 wind data was lost. These hours of lost data were accounted for in determining the wind farm capacity factor in January and February.

Wind farm $\mathrm{kW}$-power output correlates with and reduces the Eastsound annual peak load during the OPALCO 1996-1997 winter peak season. Figure 6 shows the impact of the wind farm on the Eastsound hourly loads during the 1996-1997 OPALCO peak load day, December 28, 1996. This is an unusual daily load shape for Eastsound in the winter, because peaking occurs in the evening rather than in the morning. This was caused by the unusual, heavy snowstorm. Note that this peak load is about $8000 \mathrm{~kW}$, 


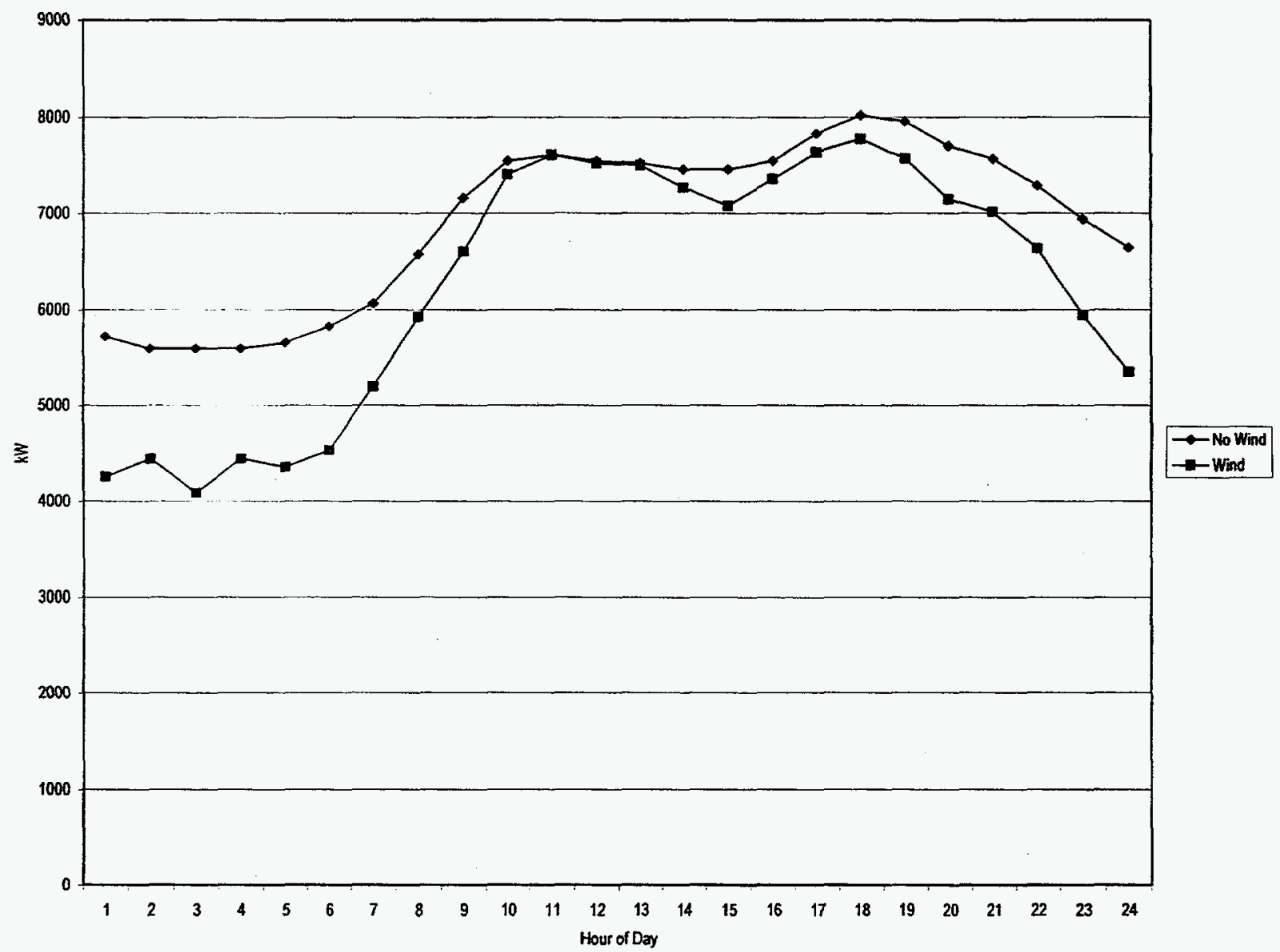

Figure 6. Wind farm impact on Eastsound load during 1996-1997 winter peak day, December 28, 1996-163 ft. (49.6 m) winds 
which is significantly less than the 1995-1996 peak load on January 30,1996 , which is more than 8500 $\mathrm{kW}$. In any case, the Eastsound peak load between 5 p.m. and 6 p.m. is still reduced $246 \mathrm{~kW}$ by the wind farm output, resulting from winds approaching $16 \mathrm{mph}$.

\section{Wind Farm Performance - Mt. Constitution at $120 \mathrm{Ft}$ (36.5 m)}

Hourly wind data were also collected at the $120 \mathrm{ft} .(36.5 \mathrm{~m})$ level. At this elevation, the resulting annual average wind speed was about $11.4 \mathrm{mph}$ from March 1995 through February 1996, and $10.7 \mathrm{mph}$ from March 1996 through February 1997. Figure 7 shows the average monthly wind speed throughout the two-year period at this elevation. In the winter months, during OPALCO's peak season, the average monthly wind speed again is relatively high, ranging up to over $16 \mathrm{mph}$. In the summer months, the average wind speed is low, averaging less than $10 \mathrm{mph}$.

Wind farm performance from March 1995 through February 1996 is summarized in Table 3, assuming the two $750-\mathrm{kW}$ variable-speed wind turbines, the wind power curve in Figure 3, and the hourly wind data are gathered at the Mt. Constitution site at $120 \mathrm{ft}$. $(36.5 \mathrm{~m})$. For these winds, annual wind farm energy production would be $2120 \mathrm{MWh}$, and the annual wind farm capacity factor would be $16.1 \%$. As discussed below, some wind data were lost in January and February. Hence, the wind farm performance would actually be higher than calculated in this study.

Figures C.1 through C.8 in Appendix C show the detailed hourly wind data collected and associated wind farm performance during OPALCO's 1995-1996 winter peak season from November 1995 through February 1996, respectively. In November and December 1995 the winds were the highest, and the expected monthly wind farm energy production was $364 \mathrm{MWh}$ and $365 \mathrm{MWh}$, respectively, resulting in monthly capacity factors of about 33\%. As at the $163 \mathrm{ft}$. (49.6 m) level, in January and February 1996, some wind data were lost (likely because of anemometer icing), reducing the calculated wind farm output significantly from January 21 through January 28, and from February 22 through February 25.

At the $120 \mathrm{ft} .(36.5 \mathrm{~m}$ ) elevation, wind farm $\mathrm{kW}$-power output correlates with and reduces the Eastsound annual peak load during the OPALCO 1995-1996 winter peak season. Figure 8 shows the impact of the wind farm on the Eastsound hourly loads during the 1995-1996 OPALCO peak load day, January 30, 1996. The Eastsound peak load between $8 \mathrm{a} . \mathrm{m}$. and 9 a.m. is reduced $464 \mathrm{~kW}$ by the wind farm output, resulting from winds more than $18 \mathrm{mph}$ at this elevation.

Wind farm performance from March 1996 through February 1997 is summarized in Table 4, assuming the two $750-\mathrm{kW}$ variable-speed wind turbines, the wind power curve in Figure 3, and the hourly wind data are gathered at the $\mathrm{Mt}$. Constitution site at $120 \mathrm{ft}$. $(36.5 \mathrm{~m})$. For these winds, annual wind farm energy production would be $1749 \mathrm{MWh}$, and the annual wind farm capacity factor would be $13.3 \%$. As discussed below, some wind data were lost in December, January, and February. Hence, the wind farm performance would actually be higher than calculated in this study.

Figures C.9 through C.16 in Appendix C show the detailed hourly wind data collected and associated wind farm performance during OPALCO's 1996-1997 winter peak season from November 1996 through February 1997, respectively. Again, in November, December, and January the winds were good, and in February the winds were poor. In December there was an unusual, big snowstorm that caused anemometer problems (likely because of anemometer icing), reducing the calculated wind farm output significantly from December 24 until December 27. From January 24 through February 3 wind data was 


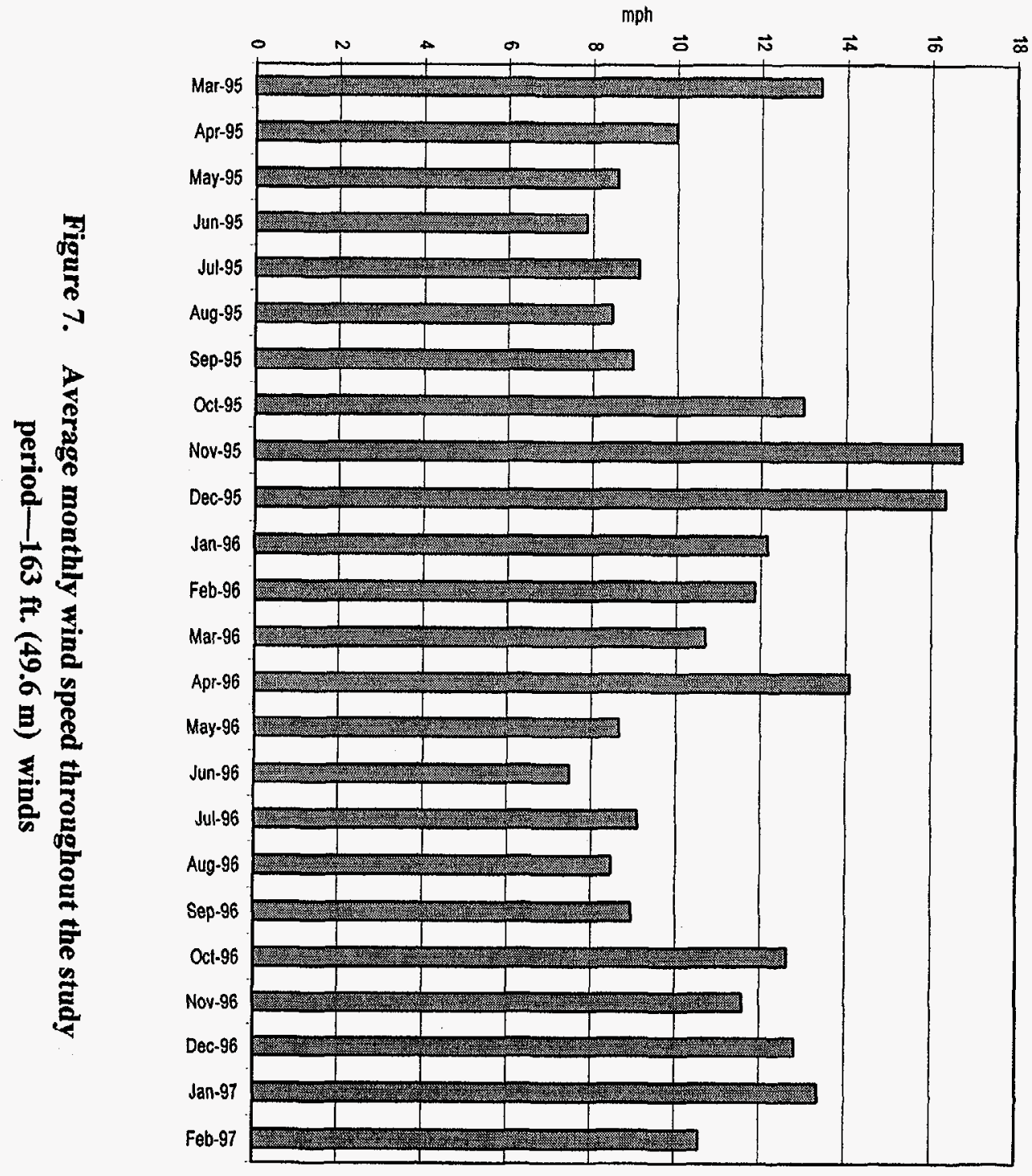




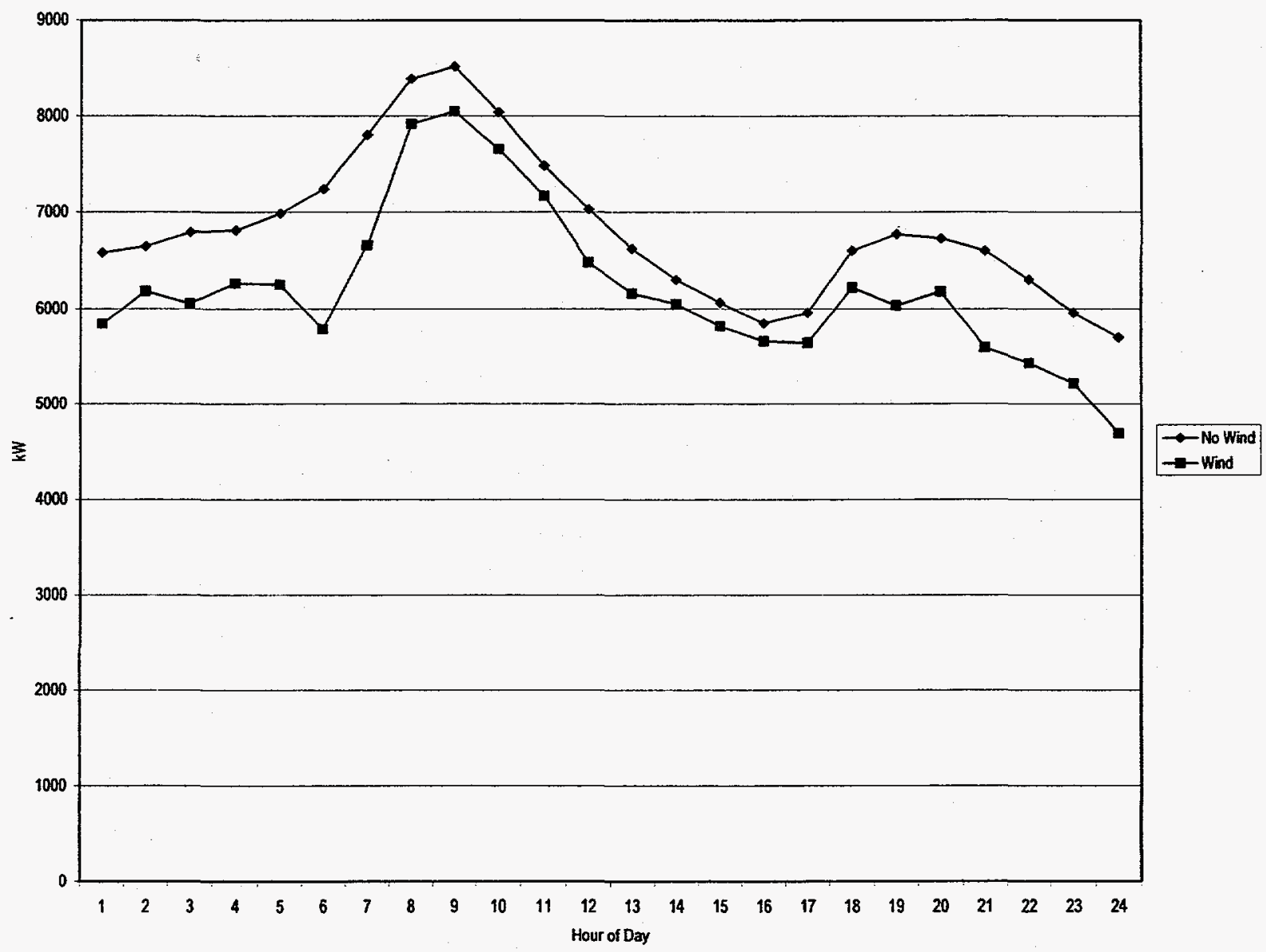

Figure 8. Wind farm impact on Eastsound load during 1995-1996 winter peak day, January 30, 1996-120 ft. (36.5 m) winds 
Table 3. Wind farm performance at 120 Ft. (36.5 m)-March 1995-February 1996

\begin{tabular}{cccc}
\hline Month & $\begin{array}{c}\text { Monthly } \\
\text { Energy } \\
\text { MWh }\end{array}$ & $\begin{array}{c}\text { Monthly } \\
\text { Capacity Factor } \\
\%\end{array}$ & $\begin{array}{c}\text { Net Peak } \\
\text { Reduction } \\
\text { kW }\end{array}$ \\
\hline Mar-95 & 281 & $25.2 \%$ & 529 \\
Apr-95 & 106 & $9.9 \%$ & 0 \\
May-95 & 53 & $4.8 \%$ & 0 \\
Jun-95 & 63 & $5.8 \%$ & 0 \\
Jul-95 & 75 & $6.7 \%$ & 43 \\
Aug-95 & 59 & $5.3 \%$ & 43 \\
Sep-95 & 63 & $5.8 \%$ & 0 \\
Oct-95 & 216 & $19.3 \%$ & 22 \\
Nov-95 & 364 & $33.7 \%$ & 0 \\
Dec-95 & 365 & $32.7 \%$ & 0 \\
Jan-96 & 259 & $23.2 \%$ & 464 \\
Feb-96 & 216 & $20.6 \%$ & 0 \\
Totals & $\mathbf{2 , 1 2 0}$ & $\mathbf{1 6 . 1 \%}$ & $\mathbf{4 6 4}$ \\
\hline
\end{tabular}

Table 4. Wind farm performance at $120 \mathrm{Ft} .(36.5 \mathrm{~m})$-March 1996-February 1997

\begin{tabular}{cccc}
\hline Month & $\begin{array}{c}\text { Monthly } \\
\text { Energy } \\
\text { MWh }\end{array}$ & $\begin{array}{c}\text { Monthly } \\
\text { Capacity Factor } \\
\%\end{array}$ & $\begin{array}{c}\text { Net Peak } \\
\text { Reduction } \\
\text { kW }\end{array}$ \\
\hline Mar-96 & 128 & $11.5 \%$ & 172 \\
Apr-96 & 267 & $24.8 \%$ & 65 \\
May-96 & 68 & $6.1 \%$ & 0 \\
Jun-96 & 38 & $3.5 \%$ & 0 \\
Jul-96 & 75 & $6.7 \%$ & 43 \\
Aug-96 & 59 & $5.3 \%$ & 43 \\
Sep-96 & 63 & $5.8 \%$ & 0 \\
Oct-96 & 228 & $20.4 \%$ & 0 \\
Nov-96 & 203 & $18.8 \%$ & 0 \\
Dec-96 & 269 & $24.1 \%$ & 96 \\
Jan-97 & 215 & $25.8 \%$ & 0 \\
Feb-97 & 136 & $14.8 \%$ & 0 \\
Totals & $\mathbf{1 , 7 4 9}$ & $\mathbf{1 3 . 3 \%}$ & 96 \\
\hline
\end{tabular}

lost. These hours of lost data were accounted for in determining the wind farm capacity factor in January and February.

Wind farm $\mathrm{kW}$-power output correlates with and reduces the Eastsound annual peak load during the OPALCO 1996-1997 winter peak season. Figure 9 shows the impact of the wind farm on the Eastsound hourly loads during the 1996-1997 OPALCO peak load day, December 28, 1996. At this elevation, the 


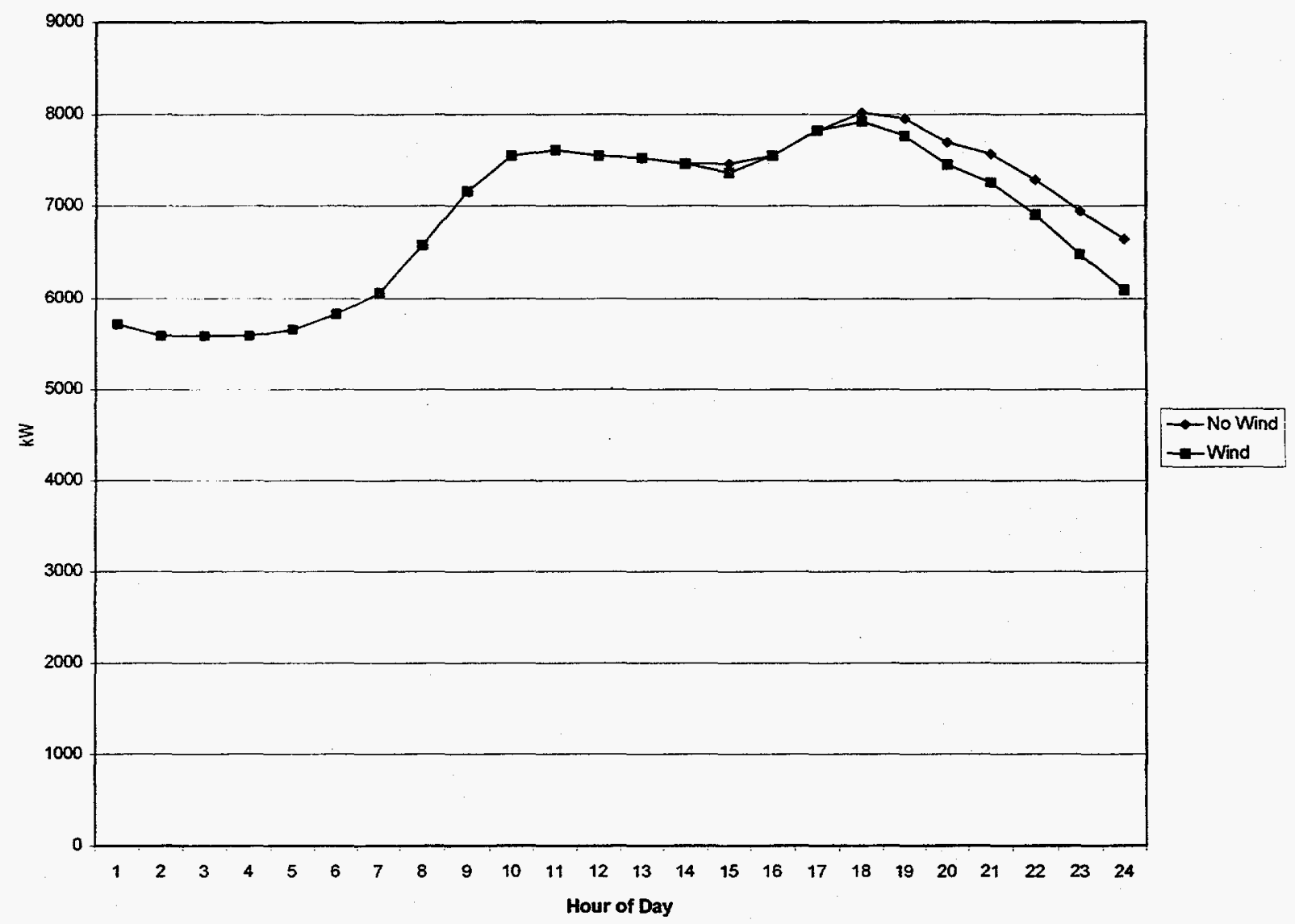

Figure 9. Wind farm impact on Eastsound load during 1996-1997 winter peak day, December 28, 1996-120 ft. (36.5 m) winds 
Eastsound peak load between 5 p.m. and 6 p.m. is reduced $96 \mathrm{~kW}$ by the wind farm output, resulting from winds approaching $13 \mathrm{mph}$.

Comparing the expected wind farm performance at the Mt. Constitution site using the measured winds at $120 \mathrm{ft} .(36.5 \mathrm{~m})$ to expected performance based on winds at $163 \mathrm{ft} .(49.6 \mathrm{~m})$, wind farm performance is clearly superior at the higher elevation. At the $163 \mathrm{ft}$. $(49.6 \mathrm{~m})$ elevation:

- In the 1995-1995 winter peak season, over 27\% more annual energy would have been produced, and the annual Eastsound peak-load energy would have been reduced $552 \mathrm{~kW}$ versus $464 \mathrm{~kW}$, and

- In the 1996-1997 winter peak season, over 29\% more annual energy would have been produced, and the annual Eastsound peak-load energy would have been reduced $246 \mathrm{~kW}$ versus $96 \mathrm{~kW}$.

\section{Wind, Temperature, and Peak-Load Correlation}

Like most utility distribution expansion plans, the requirement to upgrade the Lopez-Eastsound 25-kV distribution circuit to $69 \mathrm{kV}$ is based on $\mathrm{kW}$-power flows during projected extreme annual peak-loading conditions. In the previous study, conversations with OPALCO personnel indicated that these design extreme loading conditions are expected to occur during winter storms when there is both low temperatures (between $10^{\circ}$ to $20^{\circ} \mathrm{F}\left[-12^{\circ}\right.$ to $\left.-6^{\circ} \mathrm{C}\right]$ ) and high winds.

Therefore, temperature data were collected near Eastsound during the 1995-1996 and 1996-1997 winter seasons to observe low temperature periods, and whether there was a correlation between low temperatures, high winds, and peak-load conditions. Review of these hourly temperature data indicated that the temperature very rarely went much below $30^{\circ} \mathrm{F}$ during the winter. Hourly temperature data are plotted in Figure 10 for January 1996. On January 29 and $30\left(-1.1^{\circ} \mathrm{C}\right)$ when Eastsound peak loads over $8000 \mathrm{~kW}$ occurred, the temperature dipped below $20^{\circ} \mathrm{F}\left(-6^{\circ} \mathrm{C}\right)$ and there were high winds. Hourly temperature data are plotted in Figure 11 for December 1996. On December 28 when 1996-1997 Eastsound peak load of about $8000 \mathrm{~kW}$ occurred, the temperature was also low, approaching $20^{\circ} \mathrm{F}$ $\left(-6^{\circ} \mathrm{C}\right)$-along with high winds.

Thus, these conditions were representative of the peak-load design conditions, and there was a correlation between low temperatures and high winds during these conditions.

\section{Operational Impacts of Wind Fluctuations}

Utility system operational impacts and interactions occur on a time scale of less than one hour. One of the concerns to utilities is voltage fluctuations resulting from the inherent variability of the wind resource and wind turbine output. As part of this study, examples of high-resolution one-minute and ten-minute wind speed data were also gathered at the Mt. Constitution site to illustrate wind variability and expected MW-scale wind farm output fluctuations. These data were then analyzed on the OPALCO distribution system to determine potential voltage fluctuations resulting from variations in wind farm output. This section describes the examples of high-resolution wind data collected, calculates expected wind farm power output fluctuations, and results of potential voltage fluctuations on the distribution circuit, if the wind farm were connected to the Eastsound substation. 


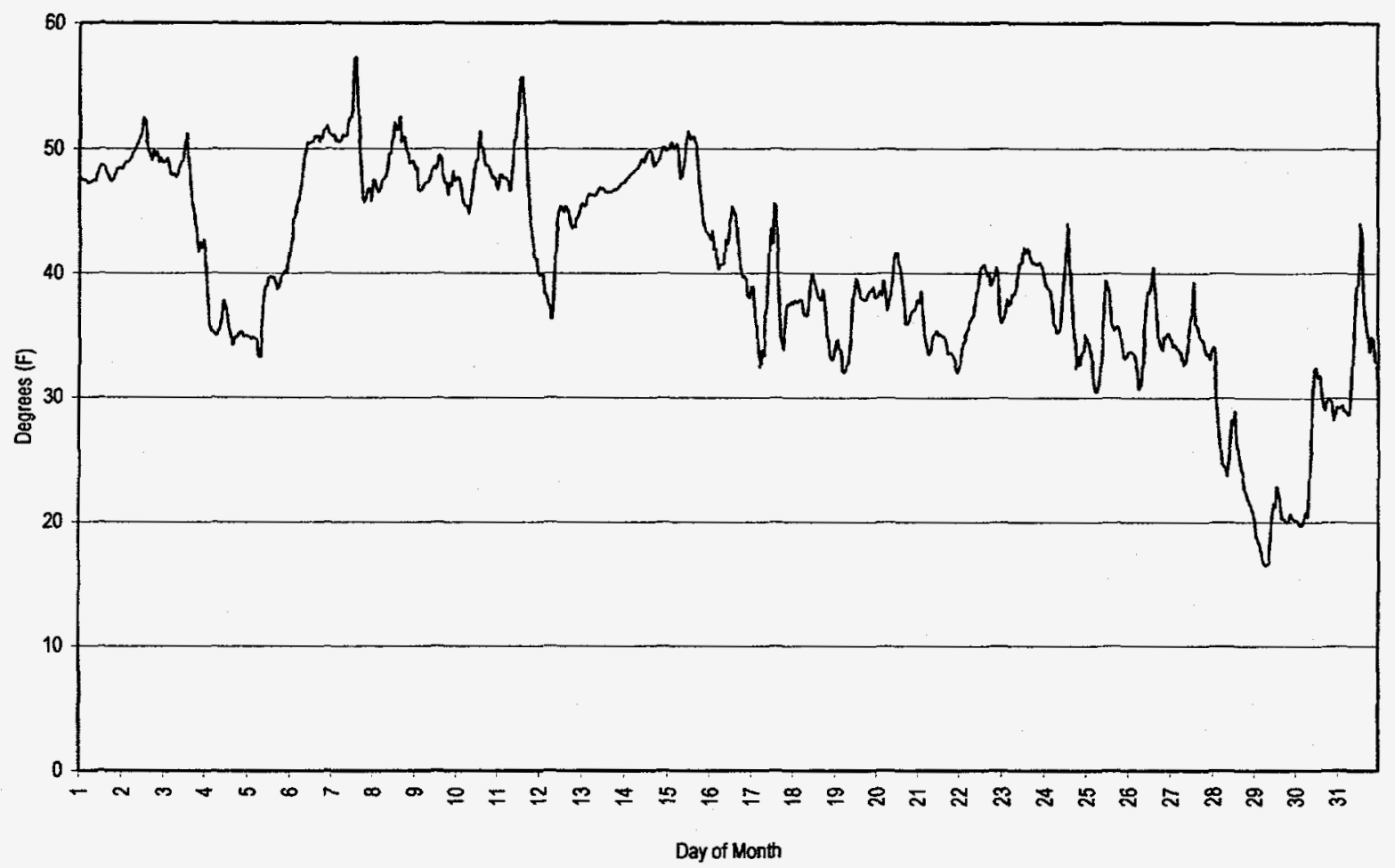

Figure 10. Hourly Orcas Island temperature in January 1996 


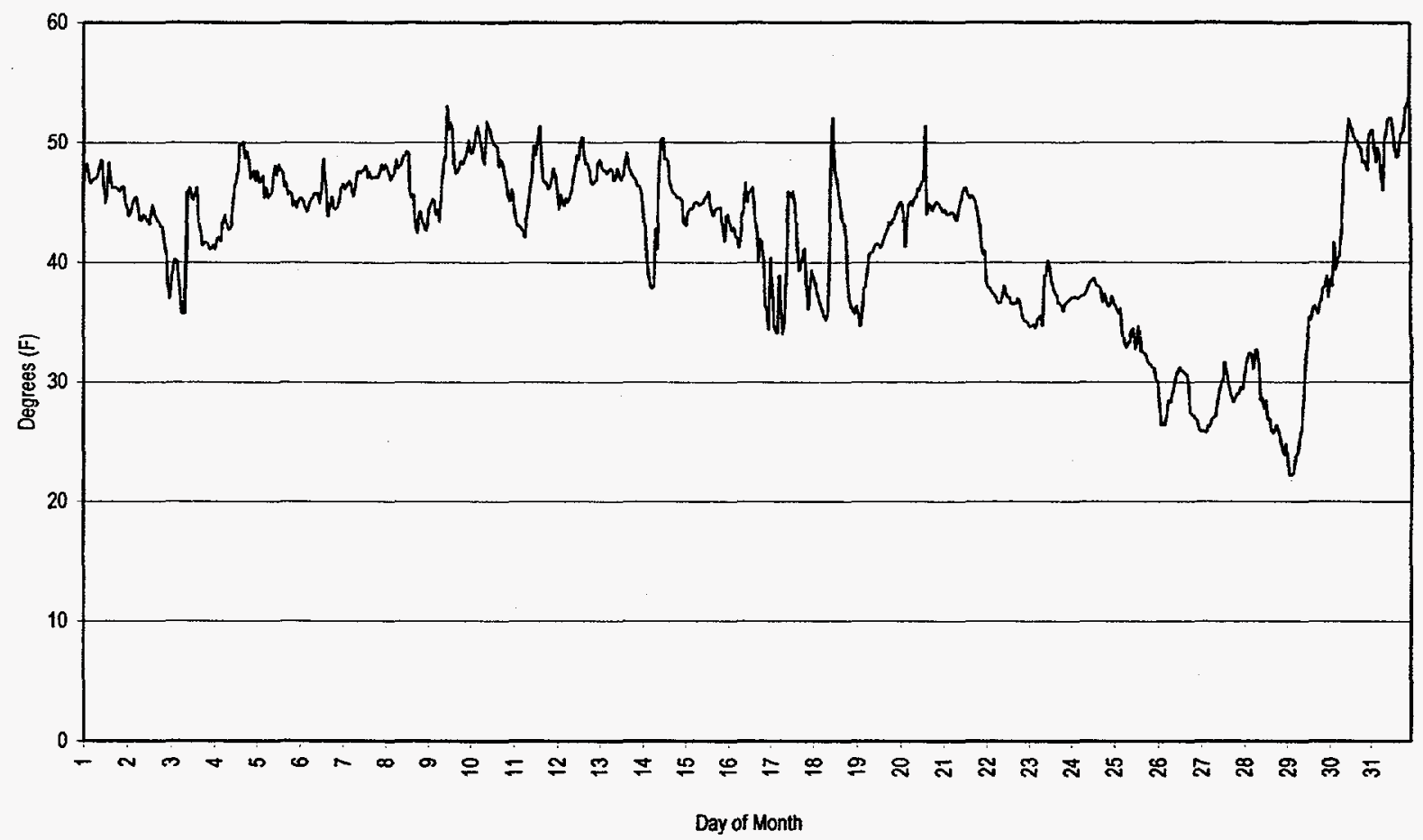

Figure 11. Hourly Orcas Island temperature in December 1996 


\section{Wind Measurements and Expected Wind Farm Output Fluctuations}

Figure 12 presents examples of ten-minute (integrated) wind data collected over a ten-day period at the Mt. Constitution site at $163 \mathrm{ft}$. $(49.6 \mathrm{~m})$ elevation. The ten-minute winds varied up to over $45 \mathrm{mph}$ during this period. Review of these data showed that the largest ten-minute wind fluctuations occurred during the early part of day 6, which is shown in detail in Figure 13. At the end of hour 1 , the integrated tenminute wind drops about $9.4 \mathrm{mph}$, from $24.3 \mathrm{mph}$ to $14.9 \mathrm{mph}$. Assuming the wind power curve in Figure 3, a 1.5-MW wind farm would experience a wind farm output fluctuation of about $960 \mathrm{~kW}$, from about $1150 \mathrm{~kW}$ to $190 \mathrm{~kW}$. During hour 6 the integrated ten-minute wind increases about $11.4 \mathrm{mph}$, from 7.3 $\mathrm{mph}$ to $18.7 \mathrm{mph}$. In this case, a $1.5-\mathrm{MW}$ wind farm would experience a wind farm output fluctuation of about $460 \mathrm{~kW}$, from no output to $460 \mathrm{~kW}$.

Figure 14 presents 23 hours of example one-minute (integrated) wind data also collected at the Mt. Constitution site at $163 \mathrm{ft}$. $(49.6 \mathrm{~m})$ elevation. These example wind data represent expected normal, everyday winds as opposed to extreme winds. To put these data in perspective, Figure 15 presents a plot of the integrated hourly wind data corresponding to these one-minute winds over the 23-hour data collection period. During this period, the hourly winds range up to about $21 \mathrm{mph}$, while the parallel oneminute winds range up to about $29 \mathrm{mph}$, and fluctuate significantly about the resulting hourly winds.

Figure 16 presents the one-minute winds in hour 1 . The average hourly wind is $17.4 \mathrm{mph}$. The oneminute winds vary between approximately $10.5 \mathrm{mph}$ and $26.6 \mathrm{mph}$. During this hour:

- The one-minute winds increase $6.7 \mathrm{mph}$ in one minute, from 11.2 to $17.9 \mathrm{mph}$. In this case, a 1.5-MW wind farm would experience a wind farm output fluctuation of about $330 \mathrm{~kW}$.

- The one-minute winds decrease $12 \mathrm{mph}$ in three minutes, from 26 to $14 \mathrm{mph}$. In this case, a $1.5-\mathrm{MW}$ wind farm would experience a wind farm output fluctuation of about $1270 \mathrm{~kW}$. Note this is almost the full output range of the 1.5-MW wind farm.

Figure 17 presents the one-minute winds in Hour 4. The average hourly wind is $21 \mathrm{mph}$. The oneminute winds vary between approximately $12.9 \mathrm{mph}$ and $29.4 \mathrm{mph}$. During this hour:

- The one-minute winds increase $7.3 \mathrm{mph}$ in one minute, from 22 to $29.3 \mathrm{mph}$. In this case, a $1.5-\mathrm{MW}$ wind farm would experience a wind farm output fluctuation of about $630 \mathrm{~kW}$.

- The one-minute winds increase $9.3 \mathrm{mph}$ in two minutes, from 20 to $29.3 \mathrm{mph}$. In two minutes, a 1.5-MW wind farm would experience a wind farm output fluctuation of about $850 \mathrm{~kW}$.

Figure 18 presents the one-minute winds in Hour 5. The average hourly wind is $20.3 \mathrm{mph}$. The oneminute winds vary between approximately $14.9 \mathrm{mph}$ and $25.8 \mathrm{mph}$. During this hour:

- The one-minute winds decrease $6.9 \mathrm{mph}$ in one minute, from 24.3 to $17.4 \mathrm{mph}$. In this case, a 1.5-MW wind farm would experience a wind farm output fluctuation of about $760 \mathrm{~kW}$.

- The one-minute winds increase $6.9 \mathrm{mph}$ in one minute, from 19 to $25.9 \mathrm{mph}$. In this case, a $1.5-\mathrm{MW}$ wind farm would experience a wind farm output fluctuation of about $740 \mathrm{~kW}$.

Figure 19 presents the one-minute winds in Hour 18 . The average hourly wind is $19.5 \mathrm{mph}$. The oneminute winds vary between approximately $12.3 \mathrm{mph}$ and $24.9 \mathrm{mph}$. During this hour:

- The one-minute winds decrease $6.9 \mathrm{mph}$ in one minute, from 24.3 to $17.4 \mathrm{mph}$. In this case, a 1.5-MW wind farm would experience a wind farm output fluctuation of about $760 \mathrm{~kW}$. 


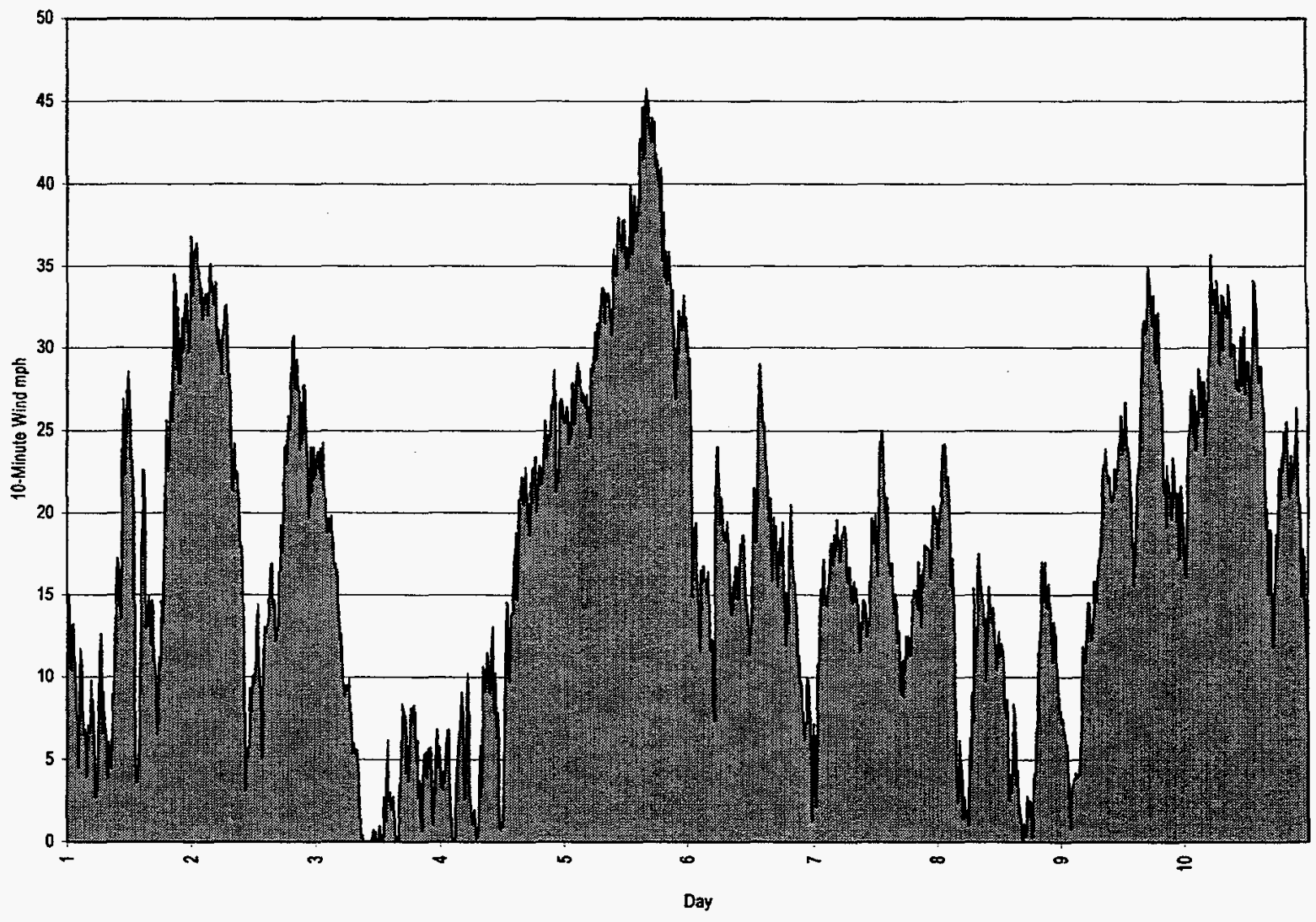

Figure 12. Ten-minute winds over an example ten-day period 


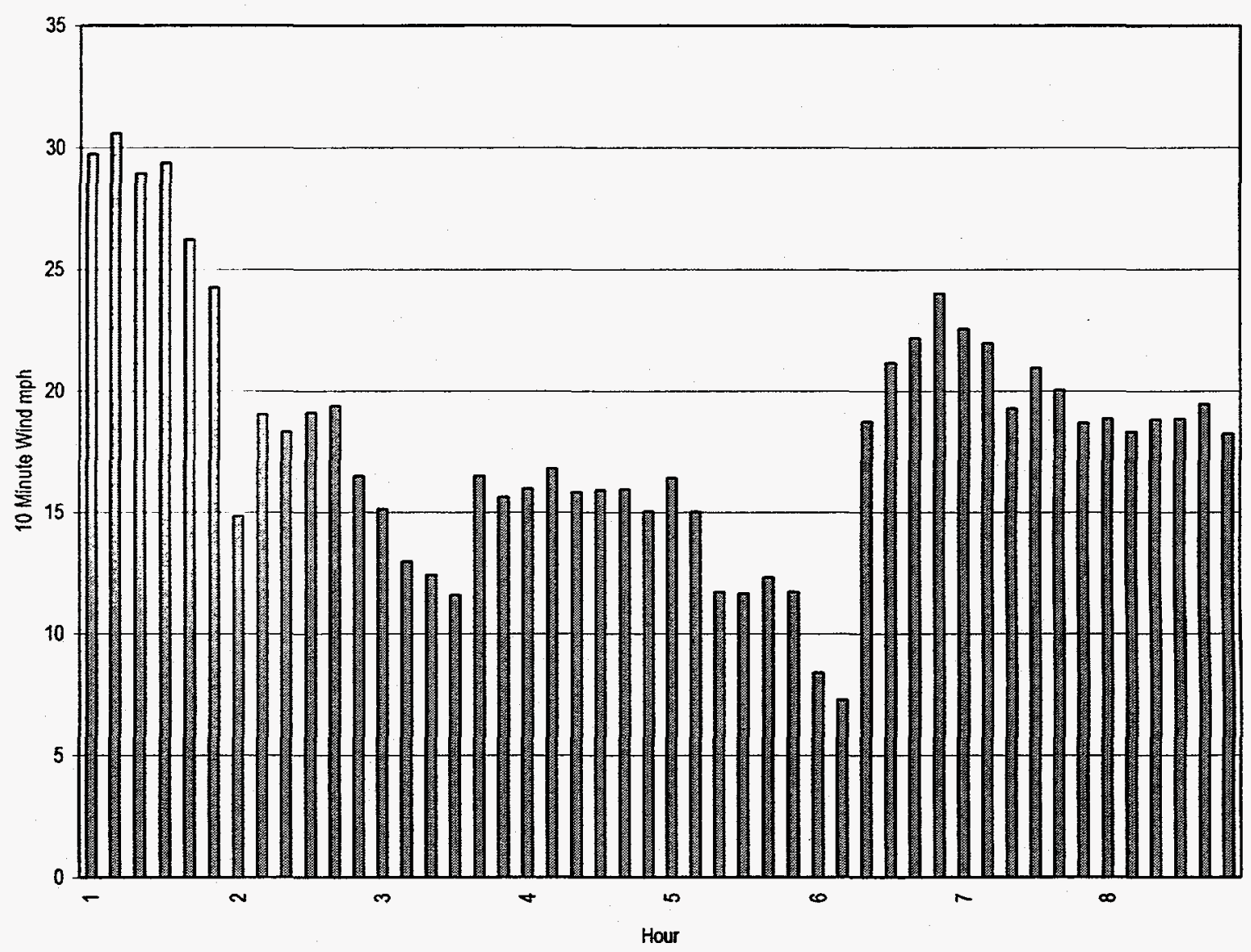

Figure 13. Hourly Orcas Island temperature in December 1996 


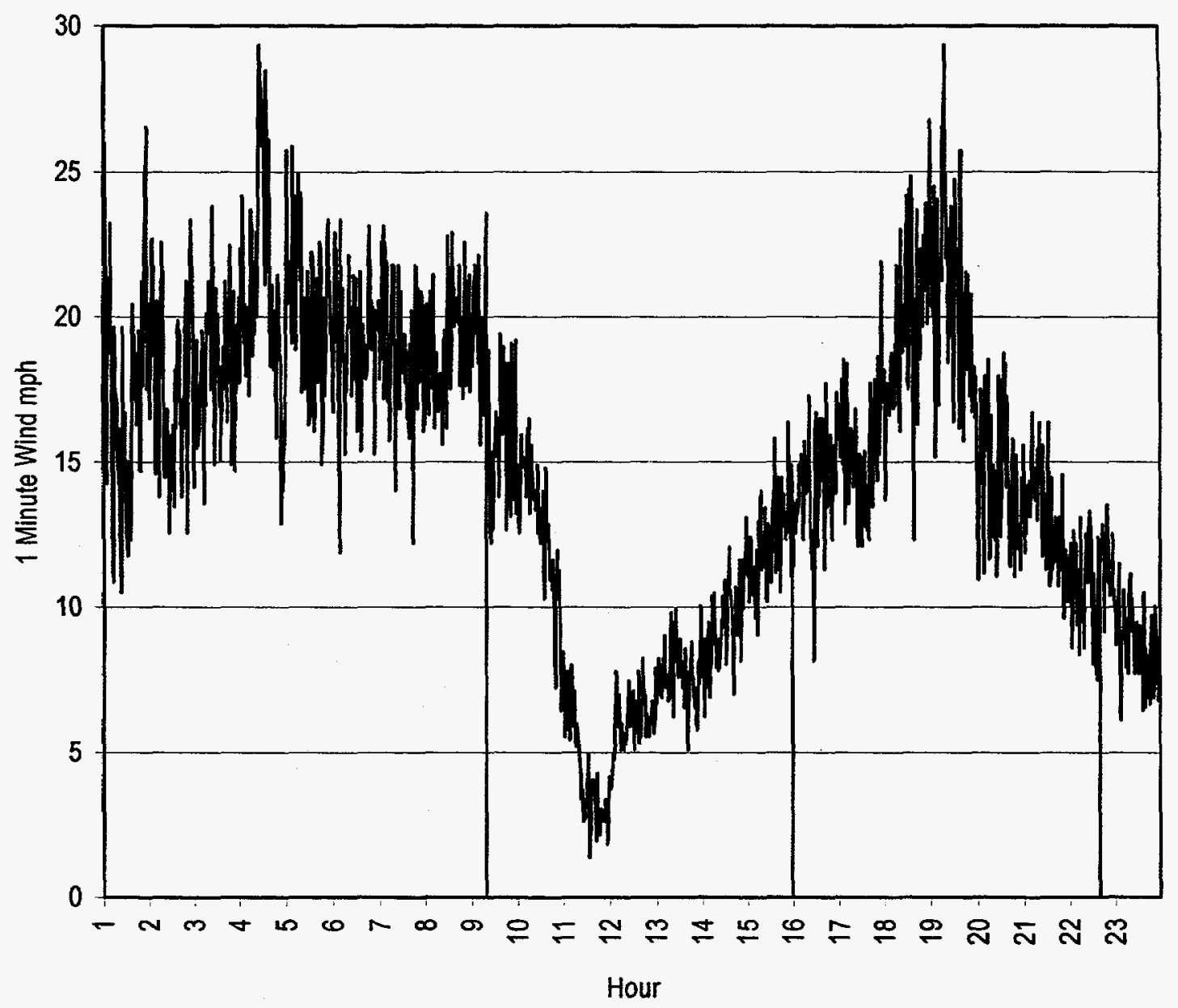

Figure 14. One-minute winds over an example 23-hour period 


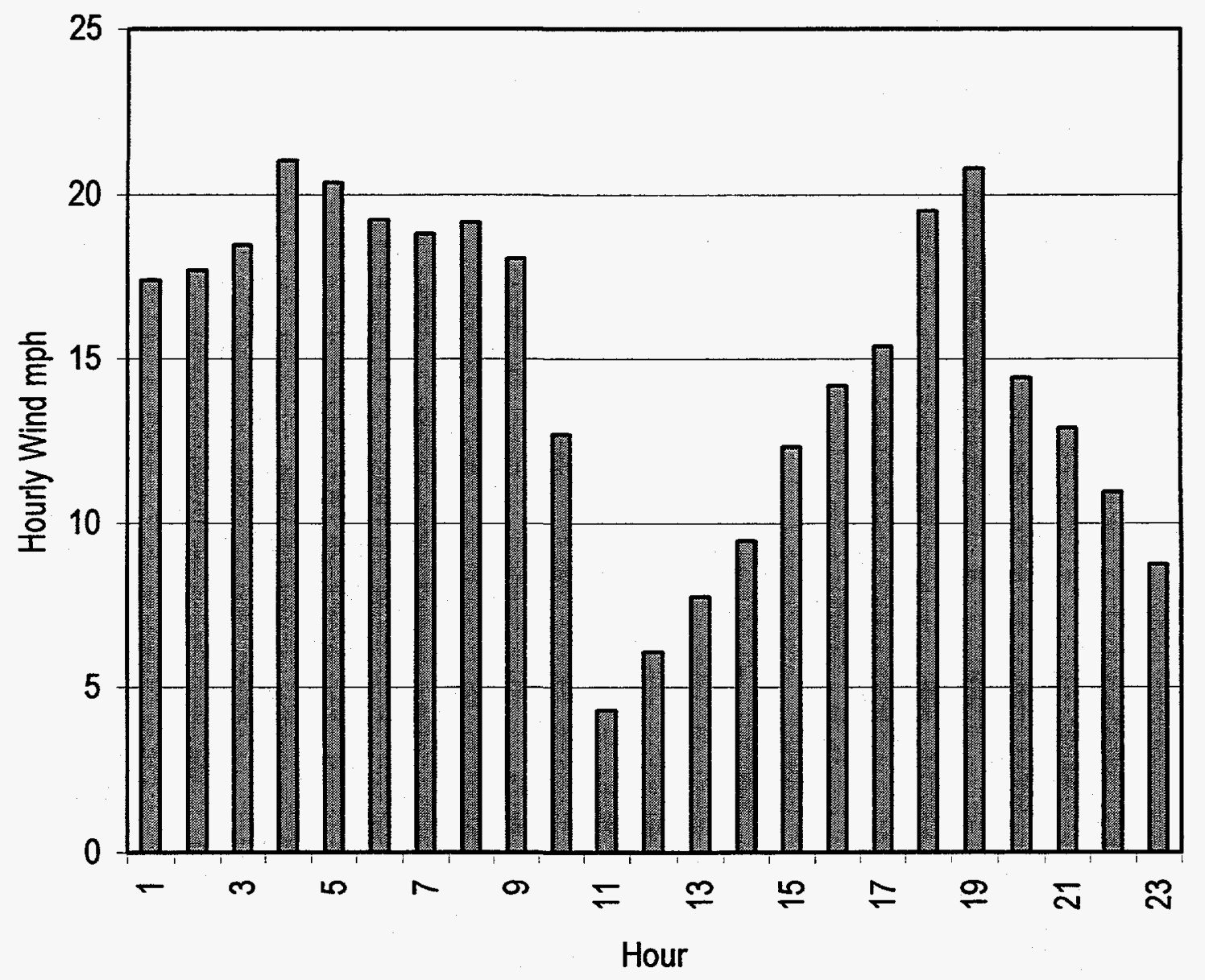

Figure 15. Corresponding hourly winds over 23-hour period 


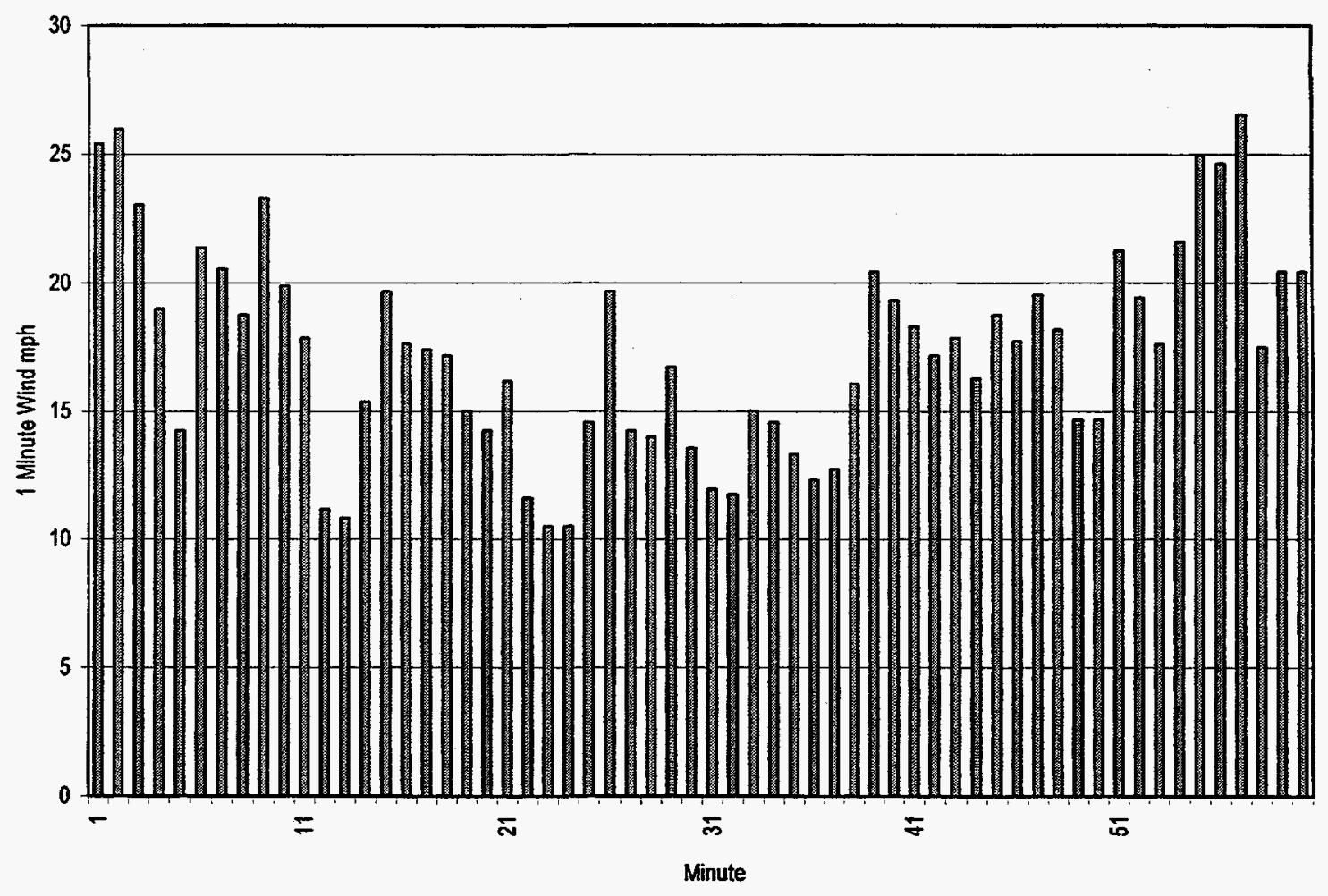

Figure 16. Minute-to-minute winds during Hour 1 


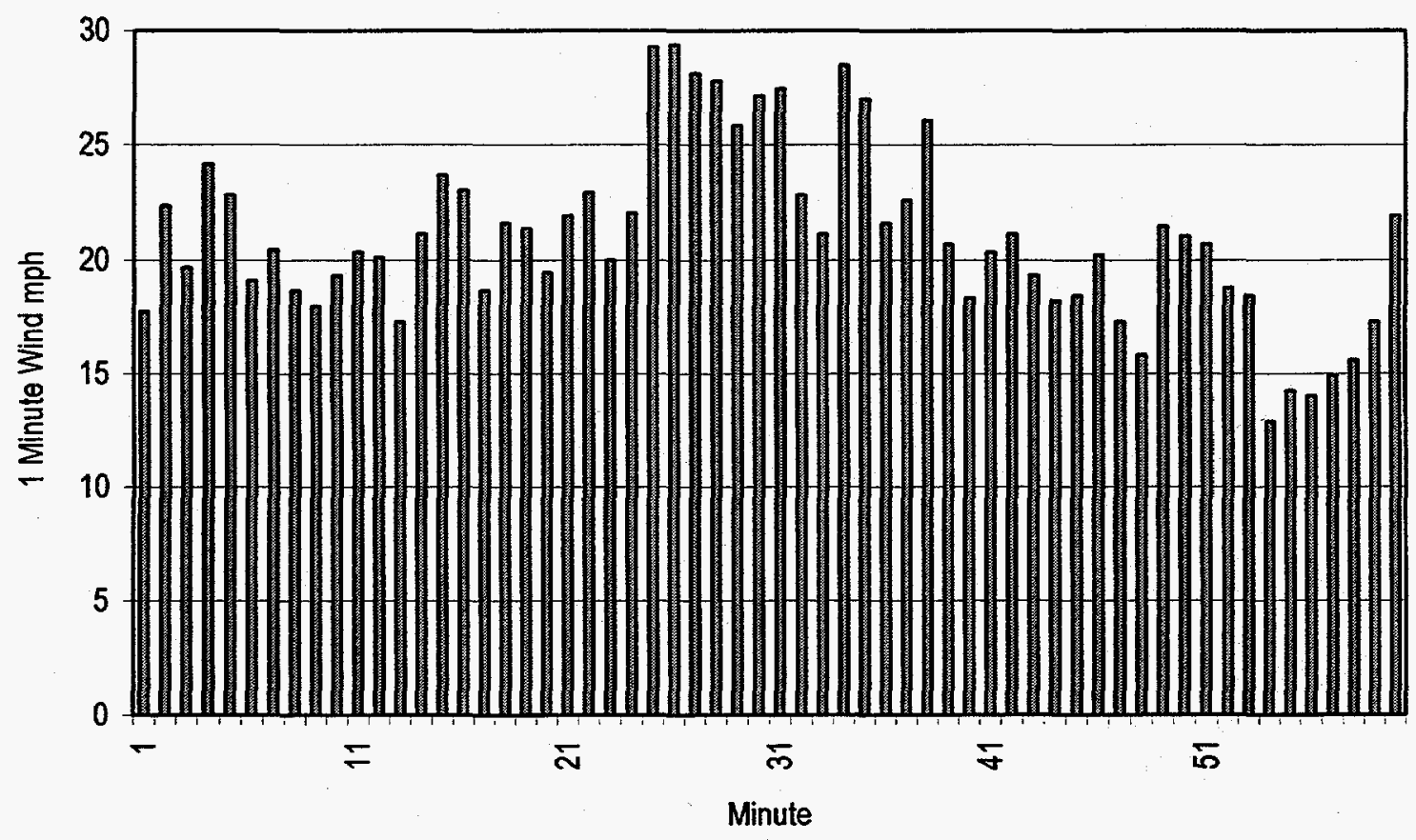

Figure 17. Minute-to-minute winds during Hour 4 


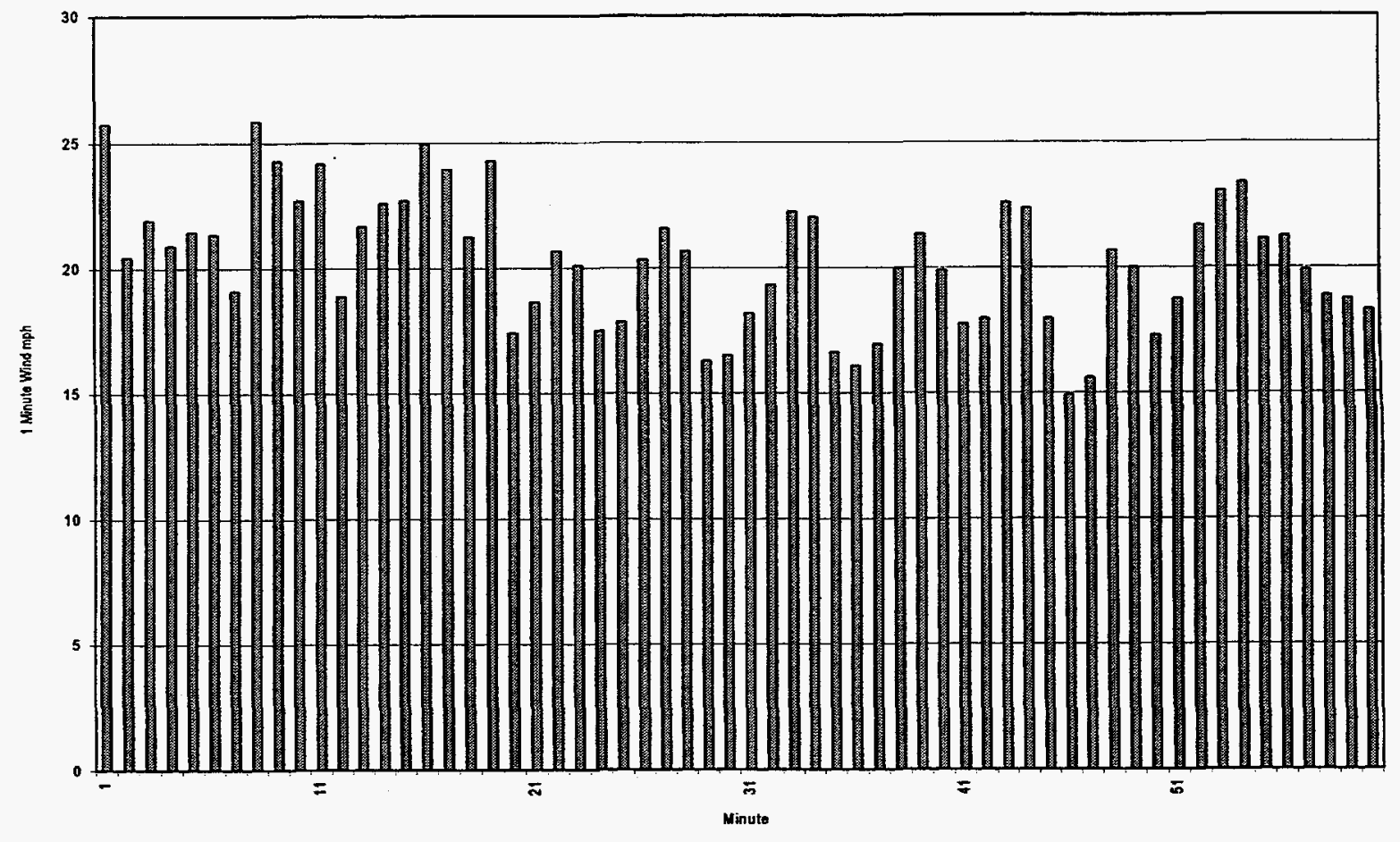

Figure 18. Minute-to-minute winds during Hour 5 


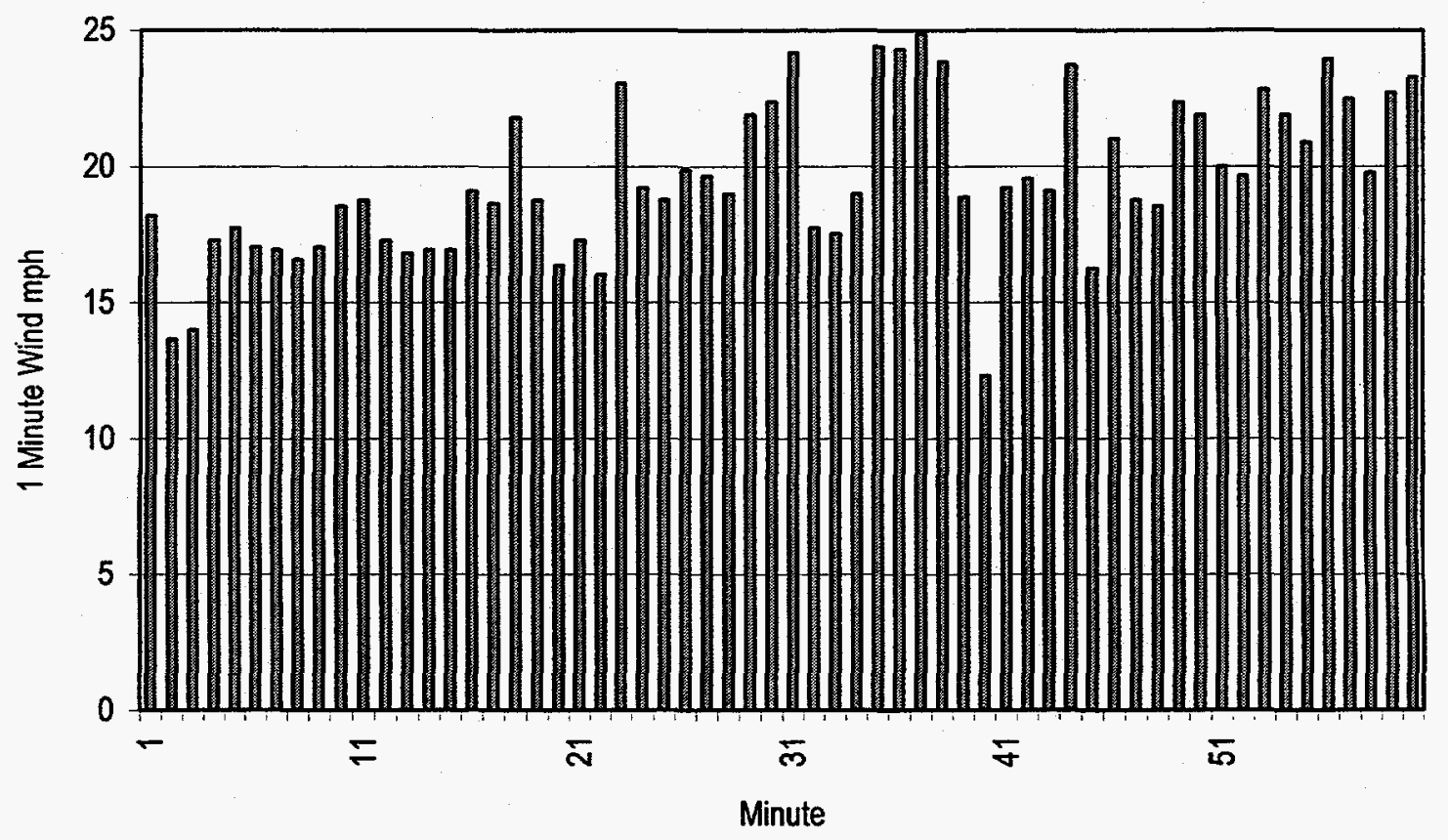

Figure 19. Minute-to-minute winds during Hour 18 
- The one-minute winds increase $6.9 \mathrm{mph}$ in one minute, from 12.3 to $19.2 \mathrm{mph}$. In this case, a 1.5-MW wind farm would experience a wind farm output fluctuation of about $460 \mathrm{~kW}$.

- The one-minute winds decrease $7.4 \mathrm{mph}$ in one minute, from 23.7 to $16.3 \mathrm{mph}$. In this case, a 1.5-MW wind farm would experience a wind farm output fluctuation of about $690 \mathrm{~kW}$.

- The one-minute winds decrease $11.5 \mathrm{mph}$ in two minutes, from 23.8 to $12.3 \mathrm{mph}$. In this case, a 1.5-MW wind farm would experience a wind farm output fluctuation of about $910 \mathrm{~kW}$.

- The one-minute winds decrease $12.6 \mathrm{mph}$ in three minutes, from 24.9 to $12.3 \mathrm{mph}$. In this case, a 1.5-MW wind farm would experience a wind farm output fluctuation of about $1050 \mathrm{~kW}$.

Figure 20 presents the one-minute winds in Hour 19. The average hourly wind is $20.8 \mathrm{mph}$. The oneminute winds vary between approximately $14.4 \mathrm{mph}$ and $29.4 \mathrm{mph}$. During this hour:

- The one-minute winds decrease $9.4 \mathrm{mph}$ in one minute, from 24.5 to $15.1 \mathrm{mph}$. In this case, a $1.5-\mathrm{MW}$ wind farm would experience a wind farm output fluctuation of about $900 \mathrm{~kW}$.

- The one-minute winds increase $9.7 \mathrm{mph}$ in two minutes, from 16.1 to $25.8 \mathrm{mph}$. In this case, a 1.5-MW wind farm would experience a wind farm output fluctuation of about $980 \mathrm{~kW}$.

These minute-to-minute wind measurements and calculations show that significant output variability can be expected for MW-scale wind farms connected to the OPALCO distribution system. These large minute-to-minute wind farm output variations are not captured when hourly or ten-minute wind data are gathered. Assuming the wind power curve in Figure 3, minute-to-minute wind variations ranging between approximately $10 \mathrm{mph}$ and $27 \mathrm{mph}$ will result in significant $\mathrm{MW}$-scale wind farm output fluctuations. Wind variations above $27 \mathrm{mph}$ and below $10 \mathrm{mph}$ will not cause large output fluctuations. Wind farms using different types of wind turbines may behave differently. However, it is expected that normal, everyday winds in the $10-$ to $30-\mathrm{mph}$ range will generally result in significant wind farm output fluctuations for most current variable-speed and induction generator wind turbine designs.

\section{Potential Distribution System Voltage Fluctuation Impacts}

The goal in this section is to consider relative voltage fluctuation impacts of different types of wind turbines likely to be installed on the OPALCO system in the late 1990s - wind farms containing induction generators and variable speed generators. The voltage performance of variable-speed wind generators and induction generators is different. Wind power curves and var production or absorption varies significantly for different wind turbine designs. Thus, the approach in this study is to identify the impact of resulting voltage fluctuations in the local OPALCO distribution system between the Mt. Constitution wind farm site and the Eastsound substation, considering an expected range of relative wind farm var requirements and wind farm $\mathrm{kW}$ output levels. The range of var requirements will represent wind farms containing the two types of wind turbines, with and without power-factor correction and the expected range of wind farm $\mathrm{kW}$ output fluctuations identified above.

Figure 21 presents a one-line diagram of the potential wind farm - Eastsound substation distribution system interconnection. The wind farm is radially connected to the Eastsound substation at the end of about eight miles of existing $12.47-\mathrm{kV}$ three phase line, with conductor sizes ranging from $350 \mathrm{MCM}$ to \#6 AWG. In this study, the impact on distribution system voltage resulting from wind farm output fluctuations has been evaluated to determine the envelope of expected performance of wind farms containing induction generators or variable-speed generators. For this configuration, the total voltage drop in the distribution circuit is a function of the wind farm output level and var supply requirements, as well as the magnitude of the loads served by the distribution feeder. 


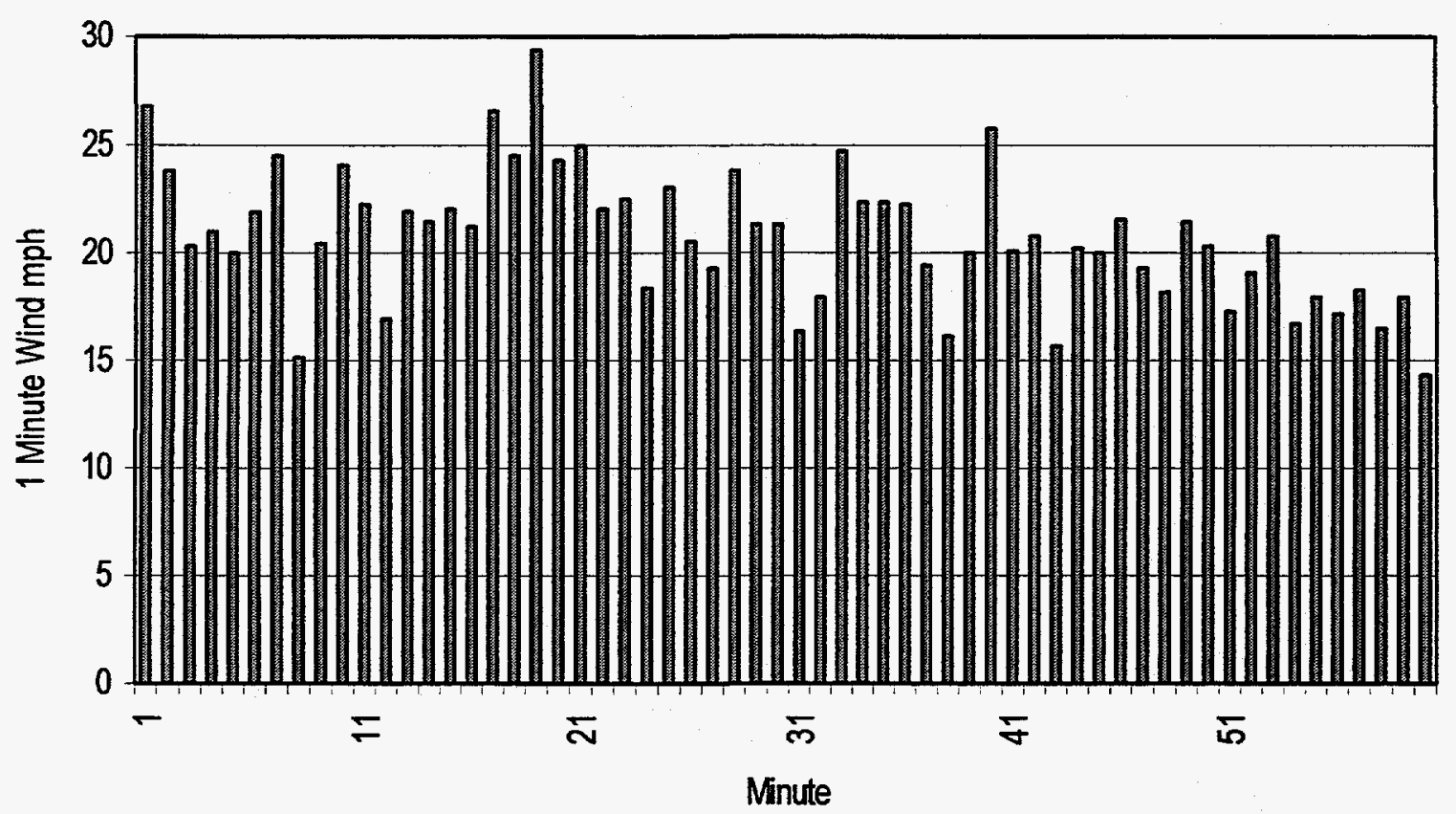

Figure 20. Minute-to-minute winds during Hour 19 


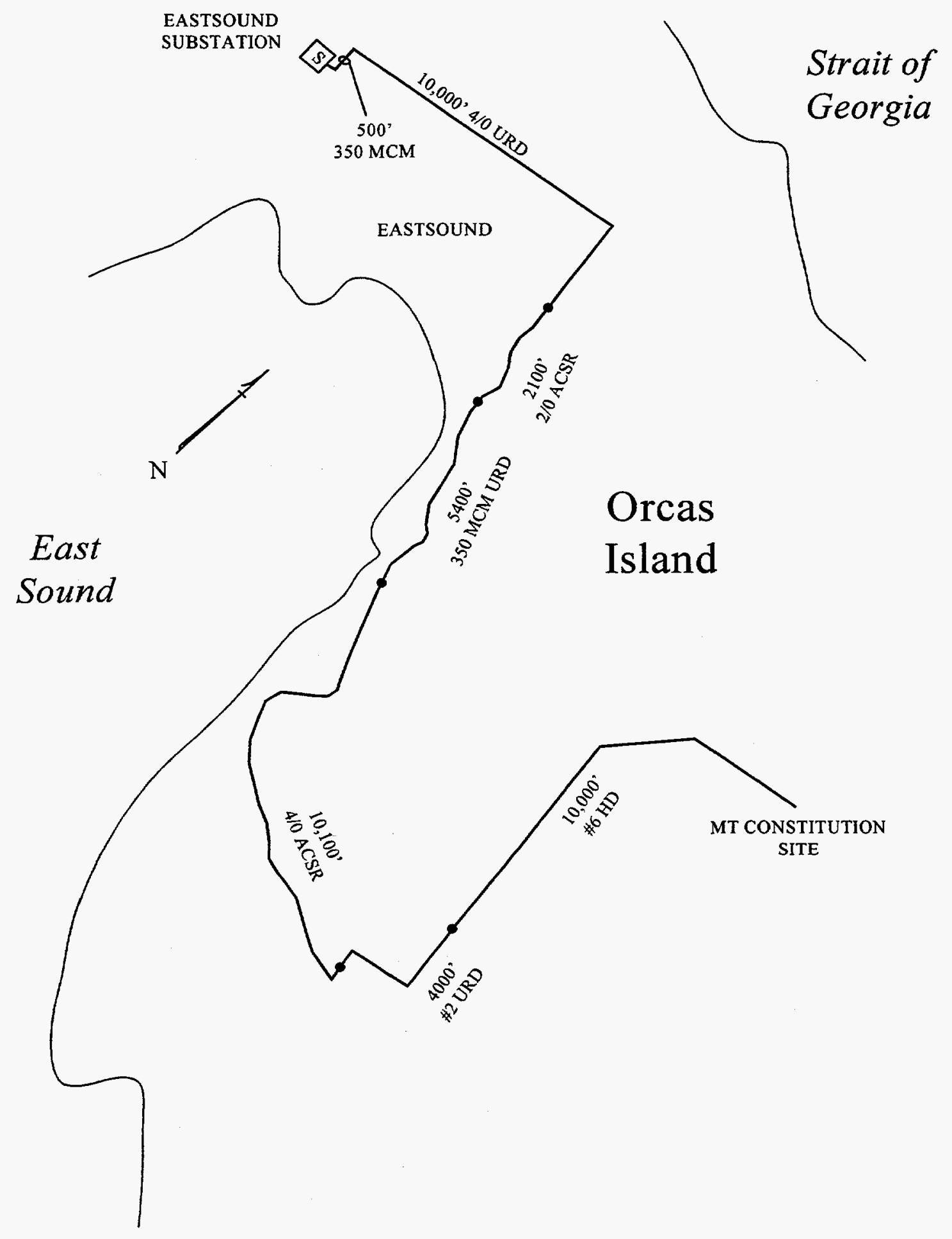

Figure 21. One-line diagram of 12.47-kV distribution circuit connecting wind farm to Eastsound substation 


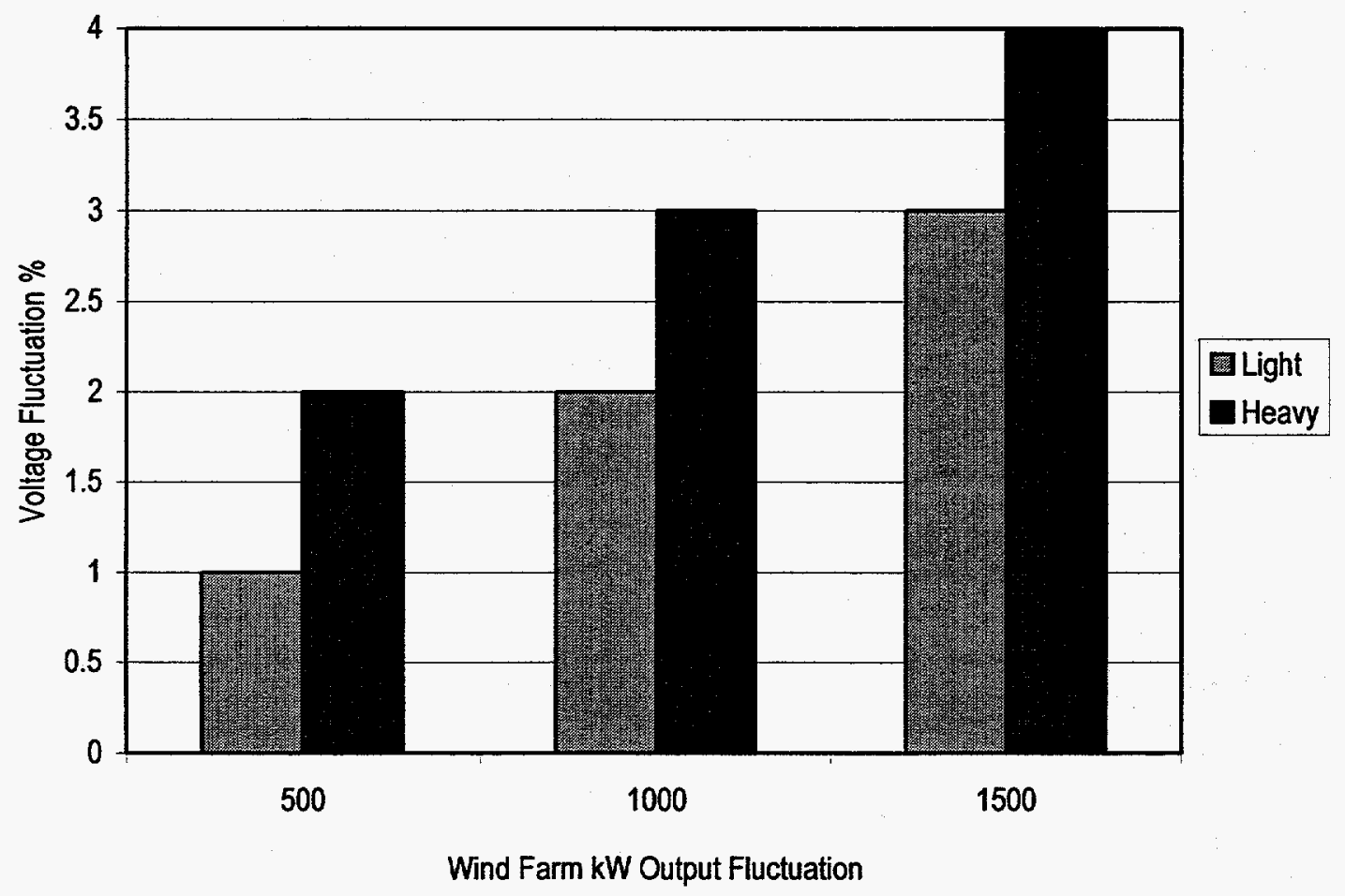

Figure 22. Range of voltage fluctuations on existing distribution circuit 
Several load flow cases were evaluated showing a range of potential minute-to-minute wind farm MW output and corresponding kvar requirements. These cases assume a $1.5-\mathrm{MW}$ wind farm is installed at the $\mathrm{Mt}$. Constitution site, and connected to the OPALCO Eastsound substation via existing $12.5-\mathrm{kV}$ lines, as shown in Figure 21 The results of the load-flow study are presented in Figure 4.22. Potential voltage fluctuations over the full range of potential wind farm output are presented. During minimum distribution circuit loading conditions, wind farm output fluctuations of about $500 \mathrm{~kW}$ result in local distribution circuit voltage fluctuations ranging up to about $2 \%$. Wind farm output fluctuations of about $1000 \mathrm{~kW}$ result in local distribution circuit voltage fluctuations ranging up to about $4 \%$. And wind farm output fluctuations of about $1500 \mathrm{~kW}$ result in local distribution circuit voltage fluctuations ranging up to about $6 \%$.

The expected range of voltage fluctuations were also calculated during heavier distribution circuit loading conditions, with $500 \mathrm{~kW}$ of load connected to the distribution circuit near the wind farm site, and another $3000 \mathrm{~kW}$ connected to the distribution circuit at other busses. In this heavier loading case, wind farm output fluctuations of about $500 \mathrm{~kW}$ result in local distribution circuit voltage fluctuations ranging up to about $3 \%$. Wind farm output fluctuations of about $1000 \mathrm{~kW}$ result in local distribution circuit voltage fluctuations ranging up to about $5 \%$. And wind farm output fluctuations of about $1500 \mathrm{~kW}$ result in local distribution circuit voltage fluctuations ranging up to about $7 \%$.

Figure 23 presents some widely accepted voltage flicker perception curves. The minute-to-minute wind data collected as part of this study and evaluated in Section 4.1, indicate that minute-to-minute wind farm output fluctuations ranging from 500 to $1000 \mathrm{~kW}$ can be expected frequently during normal everyday winds if a $1.5-\mathrm{MW}$ wind farm is installed at the Mt. Constitution site. As stated above, $500-\mathrm{kW}$ wind farm output fluctuations can cause minute-to-minute local distribution circuit voltage fluctuations in the $2 \%-3 \%$ range, and $1000-\mathrm{kW}$ output fluctuations can cause voltage fluctuations in the $4 \%-5 \%$ range. These expected minute-to-minute voltage fluctuations are above acceptable voltage flicker levels.

Because minute-to-minute distribution voltage fluctuations are above these widely accepted voltage fluctuation levels, several potential ways to mitigate the problem have been investigated as part of this project. First, one potential solution is to upgrade the local distribution circuit-reconduct the $10,000 \mathrm{ft}$. (convert) of small \#6 AWG conductor going up the mountain to the wind site.

Several more load-flow cases were examined in which the wind farm is connected to the OPALCO Eastsound substation as before, except the $10,000 \mathrm{ft}$. (convert) of \#6 AWG conductor is replaced with 4/0 ACSR. The results of these load flow calculations are presented in Figure 24. Again, potential voltage fluctuations over the full range of potential wind farm output are presented. During minimum distribution circuit loading conditions, wind farm output fluctuations of about $500 \mathrm{~kW}$ result in local distribution circuit voltage fluctuations ranging up to about $1 \%$. Wind farm output fluctuations of about $1000 \mathrm{~kW}$ result in local distribution circuit voltage fluctuations ranging up to about $2 \%$. And wind farm output fluctuations of about $1500 \mathrm{~kW}$ result in local distribution circuit voltage fluctuations ranging up to about $3 \%$. During the heavier distribution circuit loading conditions, wind farm output fluctuations of about $500 \mathrm{~kW}$ result in local distribution circuit voltage fluctuations ranging up to about $2 \%$. Wind farm output fluctuations of about $1000 \mathrm{~kW}$ result in local distribution circuit voltage fluctuations ranging up to about $3 \%$. And wind farm output fluctuations of about $1500 \mathrm{~kW}$ result in local distribution circuit voltage fluctuations ranging up to about $4 \%$. 


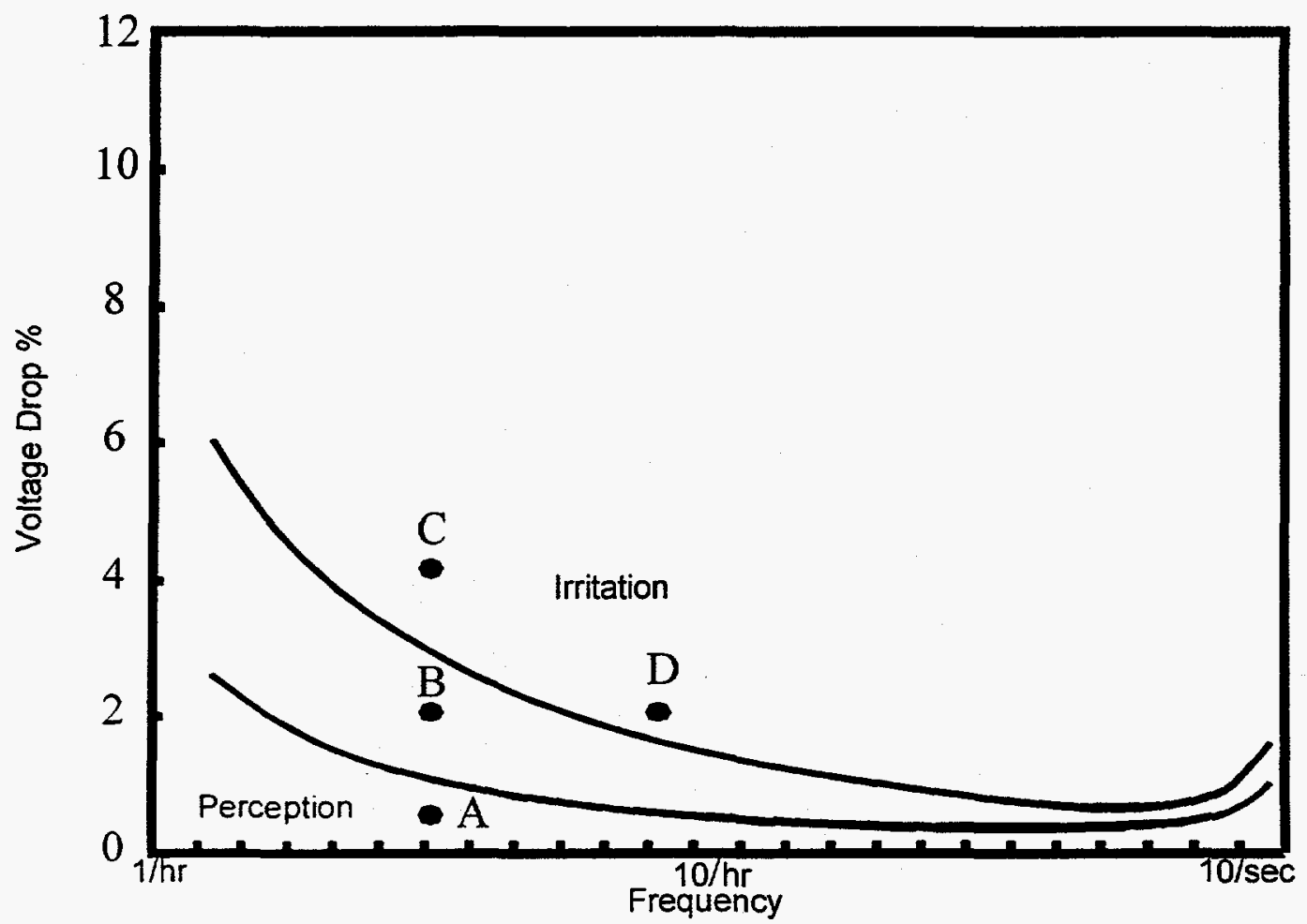

Figure 23. Voltage flicker perception curves

In this case, with the \#6 AWG conductors replaced, $500-\mathrm{kW}$ wind farm output fluctuations now only cause minute-to-minute local distribution circuit voltage fluctuations in the $1 \%-2 \%$ range, and $1000-\mathrm{kW}$ output fluctuations now only cause voltage fluctuations in the $2 \%-3 \%$ range. The expected minute-tominute voltage fluctuations now appear to be within acceptable voltage flicker levels.

A second potential solution is to perform voltage regulation with the wind farm generators. If the wind farm contains units with variable-speed generators like the Zond Z-46 generators used to provide the power curve in this study, the wind farm probably can be designed to instantly supply a variable range of vars to provide local voltage regulation, reducing potential minute-to-minute voltage fluctuations on the local distribution system. Our experience indicates that currently, wind farms with variable-speed generators are not operated in this manner, in which they supply variable vars on demand to provide distribution system voltage regulation. Instead, they are normally set to supply a specified level of vars or to maintain a specified power factor.

Several more load flow cases were examined in which the $1.5-\mathrm{MW}$ wind farm is connected to the OPALCO Eastsound substation as before, and assumed to provide variable positive or negative vars as required up to a maximum of $750 \mathrm{kvar}$. The results of these load flow calculations are presented in Figure 24. Again, potential voltage fluctuations over the full range of potential wind farm output are presented. During minimum distribution circuit loading conditions, wind farm output fluctuations of $500 \mathrm{~kW}$ or less result in no local distribution circuit voltage fluctuations. Wind farm output fluctuations of about $1000 \mathrm{~kW}$ result in local distribution circuit voltage fluctuations ranging up to about $2 \%$. And wind farm output fluctuations of about $1500 \mathrm{~kW}$ result in local distribution circuit voltage fluctuations ranging up to about $4 \%$. During the heavier distribution circuit loading conditions, wind farm output fluctuations of $500 \mathrm{~kW}$ or less result in no local distribution circuit voltage fluctuations. 


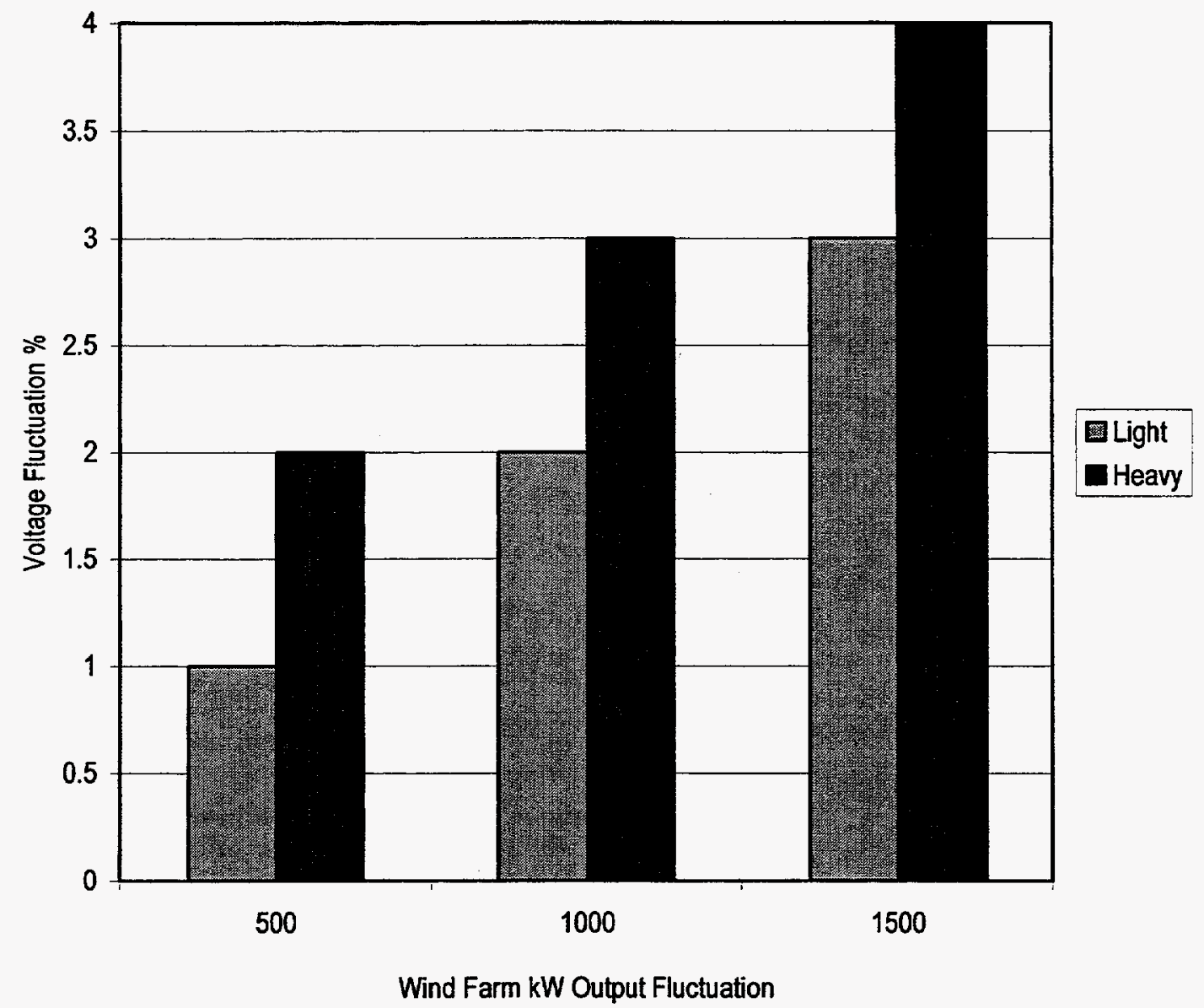

Figure 24. Range of voltage fluctuations with \#6 AWG replaced with 4/0 ACSR 
Wind farm output fluctuations of about $1000 \mathrm{~kW}$ result in local distribution circuit voltage fluctuations ranging up to about $3 \%$. And wind farm output fluctuations of about $1500 \mathrm{~kW}$ result in local distribution circuit voltage fluctuations ranging up to about $5 \%$.

In this case, with the wind farm providing voltage regulation, wind farm output fluctuations of $500 \mathrm{~kW}$ or less do not cause minute-to-minute local distribution circuit voltage fluctuations, and $1000-\mathrm{kW}$ output fluctuations now only cause voltage fluctuations in the $2 \%-3 \%$ range. The expected minute-to-minute voltage fluctuations continue to appear to be within acceptable voltage flicker levels, and are less than or equal to the magnitude of the voltage fluctuations experienced if the existing \#6 AWG portion of the distribution circuit is reconductored.

A third potential solution is to perform voltage regulation at the wind farm site with a power enhancement and delivery system (PEDS), similar to the PEDS system currently being developed by Power Technologies, Inc. The PEDS system is being developed to deliver a premium level of power quality, and is designed to enhance local voltage regulation by controlling both minute-to-minute wind farm (or other distributed renewable resource) power output swings with energy storage as well as instantaneously supplying a variable range of vars. This is a more effective way of controlling voltage fluctuations caused by minute-tominute wind farm swings than employing var control only.

Properly sized, a PEDS system can eliminate minute-to-minute voltage fluctuations and associated voltage flicker problems from a wind farm installed at the Mt. Constitution site. This alternative may be employed if the wind farm does not contain variable speed generators, or if it is determined that variable-speed generators can not supply the wide range of instantaneous positive and negative vars as required for voltage regulation.

\section{Conclusions}

The results of this study support the results of the previous work. Adding a MW-scale wind farm at the Mt. Constitution site is a feasible alternative to upgrading the $25-\mathrm{kVL}$ Lopez-Eastsound circuit to $69 \mathrm{kV}$ in 2000. Wind data collection results in this study as well as in the previous study indicate that Mt. Constitution is a good wind site. Assuming the measured winds at the instrument height of $163 \mathrm{ft}$. $(49.6 \mathrm{~m})$, the resulting annual capacity factor for a wind farm installed at this location would have been $21.2 \%$ in $1994-1995,20.5 \%$ in $1995-1996$, and $17.5 \%$ in $1996-1997$. Measured wind data indicated good correlation between high winds and projected annual Eastsound peak load over the three-year measurement period. A wind speed of approximately $22 \mathrm{mph}$ was measured during the actual annual 1994-995 winter peak load. A wind speed of approximately $20 \mathrm{mph}$ was measured during the actual annual 1995-1996 winter peak load. And a wind speed of approximately $16 \mathrm{mph}$ was measured during the actual annual 1996-1997 winter peak load.

Projected annual extreme peak-loading conditions on the OPALCO system did occur during the 19951996 winter peak season. During this extreme peak-loading condition, there was correlation between low temperature and high wind. During this design peak-loading condition, a 1.5-MW wind farm would have reduced the annual Eastsound peak load by $552 \mathrm{~kW}$.

Sample high-resolution wind data were collected during this study during normal everyday winds. These data indicate that minute-to-minute winds vary significantly about the mean hourly winds. Calculations showed that these wind variations can cause frequent large minute-to-minute wind farm output 
fluctuations, ranging up to over $1000 \mathrm{~kW}$ for a $1.5-\mathrm{MW}$ wind farm installed at the Mt. Constitution wind site.

A preliminary assessment of potential power flows from the wind farm to Eastsound substation using an existing $12.47 \mathrm{kV}$ distribution circuit was performed as part of this study. These calculations were made to determine the magnitude of expected local distribution system voltage fluctuations associated with these large minute-to-minute wind farm output variations and expected var performance. These initial calculations showed that expected frequent minute-to-minute voltage fluctuations would be above acceptable voltage flicker levels.

Three alternative methods of mitigating voltage flicker problems were evaluated in this study. First, a portion of the distribution circuit containing small conductors could be reconductored. Second, variablespeed wind generators capable of providing a large variable range of vars could be operated in a voltage regulation mode. Third, PEDS could be employed. All three methods resulted in reducing voltage flicker levels to acceptable levels. Thus, voltage flicker problems are an important consideration but are not expected to be a "show stopper" for rural distribution system wind farm installations. However, additional, more detailed studies are required to determine the best way to reduce these voltage problems for this application.

It is expected that similar results will occur when adding a MW-scale wind farm to rural distribution systems for many other utilities. First, for many winter peaking utilities throughout the northern United States, distribution circuit upgrades are also likely to be based on extreme annual winter peak design loads, which occur during coincident low-temperature and high-wind ambient conditions. Second, rural distribution systems on many other utilities are also expected to contain long distribution circuits with small conductors. MW-scale wind farm installations at the end of these rural feeders may also need minute-to-minute voltage fluctuation performance and means to mitigate potential voltage problems.

\section{References}

1. Barnes, P. R.; Van Dyke, J. W.; Tesche, F. M.; Zaininger, H.W.(June 1994). The Integration of Renewable Energy Sources Into Electric Power Distribution Systems, Volume I, National Assessment. ORNL-6775/V1. Work was prepared by the Oak Ridge National Laboratory, Manager by Martin Marietta Energy Systems, Inc. for the U.S. Department of Energy under contract DE-AC05-84OR21400.

2. Zaininger, H. W.; Ellis, P. R.; Schaefer, J. C. (June 1994). The Integration of Renewable Energy Sources Into Electric Power Distribution Systems, Volume II: Utility Case Assessments. ORNL$6775 /$ V2. Work was prepared by Zaininger Engineering Company, Inc. under Subcontract 15XSK724V for the Power Systems Technology Program Energy Division, Oak Ridge National Laboratory, managed by Martin Marietta Energy Systems, Inc. for the U.S. Department of Energy under Contract DE-AC05-84OR21400.

3. Zaininger, H. W.; Barnes, P. R. (March 1997). Applying Wind Turbines and Battery Storage to Defer Orcas Power \& Light Company Distribution Circuit Upgrades. ORNL-Sub/96-SV115/1. Work was prepared by Zaininger Engineering Company Inc. and partially cosponsored by the Utility Battery Storage Systems Program, Sandia National Laboratories, managed by Lockheed Martin Research Corporation for the U.S. Department of Energy under Contract DE-AC04-94AL85000, and by the Power Systems Technology Program, Energy Division, Oak Ridge National Laboratory under Subcontract 15X-SK724V, managed by Lockheed Martin Research Corporation for the U.S. Department of Energy under Contract DE-AC05-960R22464. 


\title{
APPENDIX A
}

\section{Hourly Eastsound Loads During 1995-1996 and 1996-1997 Winter Peak Seasons}

\begin{abstract}
Eastsound is served from Cable Number 3, where circuit integrated hourly loads are metered. Conversations with Orcas Power and Light personnel indicated that the Eastsound portion of the total hourly cable load was approximately $43 \%$ throughout the two-year study period. Figures A.1 through A.4 present the resulting hourly Eastsound loads monthly from November 1995 through February 1996, respectively. Figures A.5 through A.8 present the resulting hourly Eastsound loads monthly from November 1996 through February 1997, respectively.
\end{abstract}




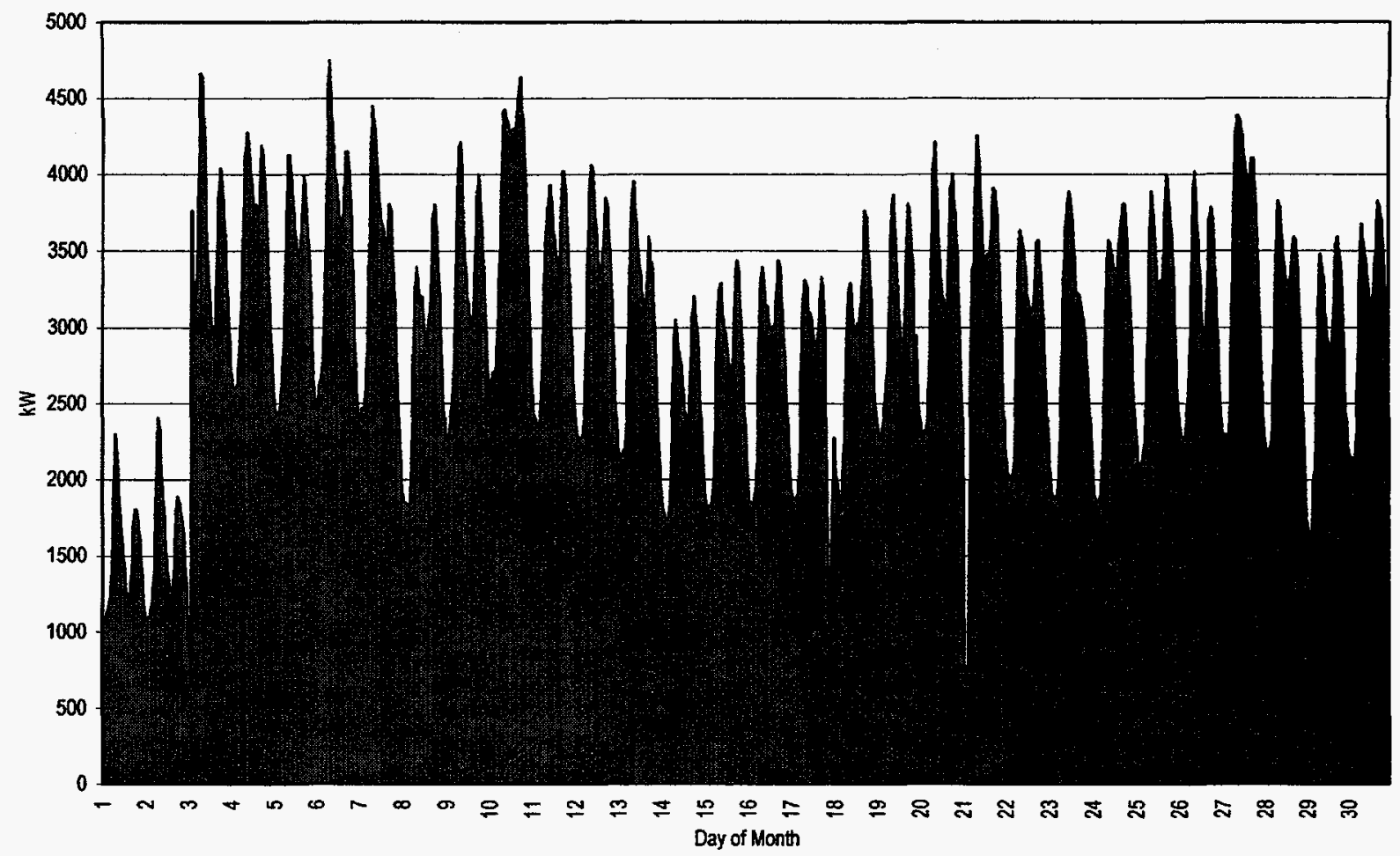

Figure A.1. Hourly Eastsound load—November 1995

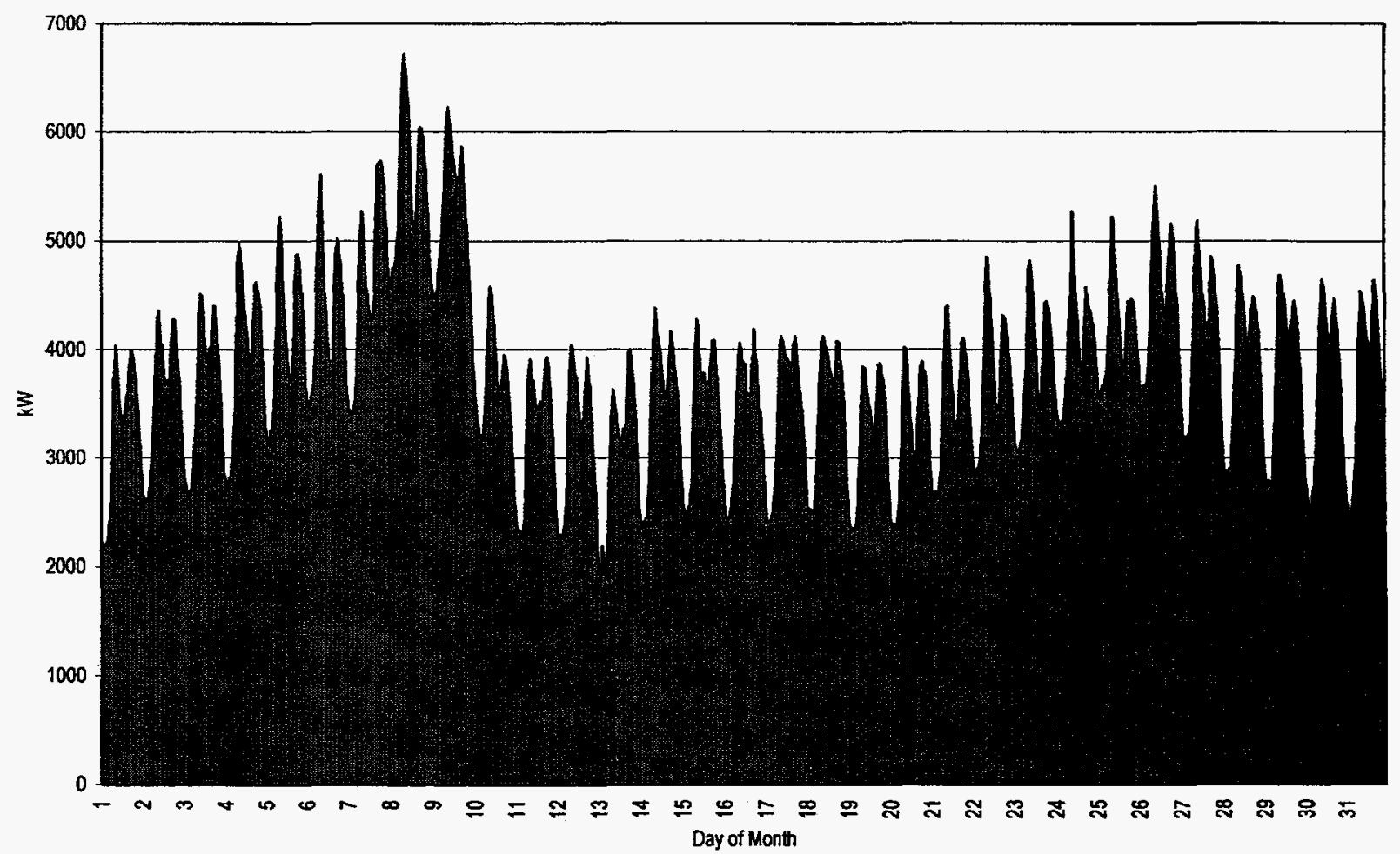

Figure A.2. Hourly Eastsound load—December 1995 


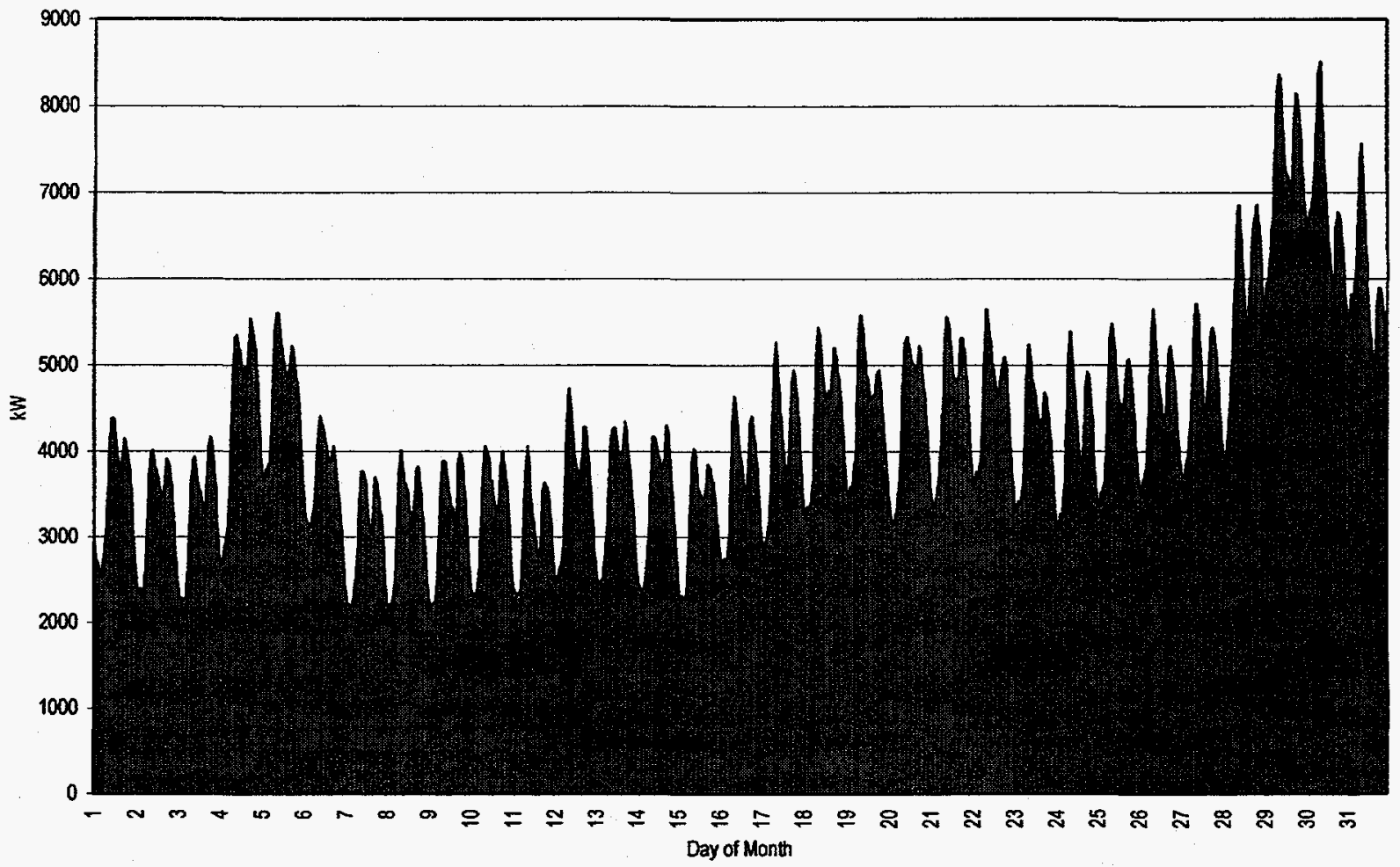

Figure A.3. Hourly Eastsound load—January 1996

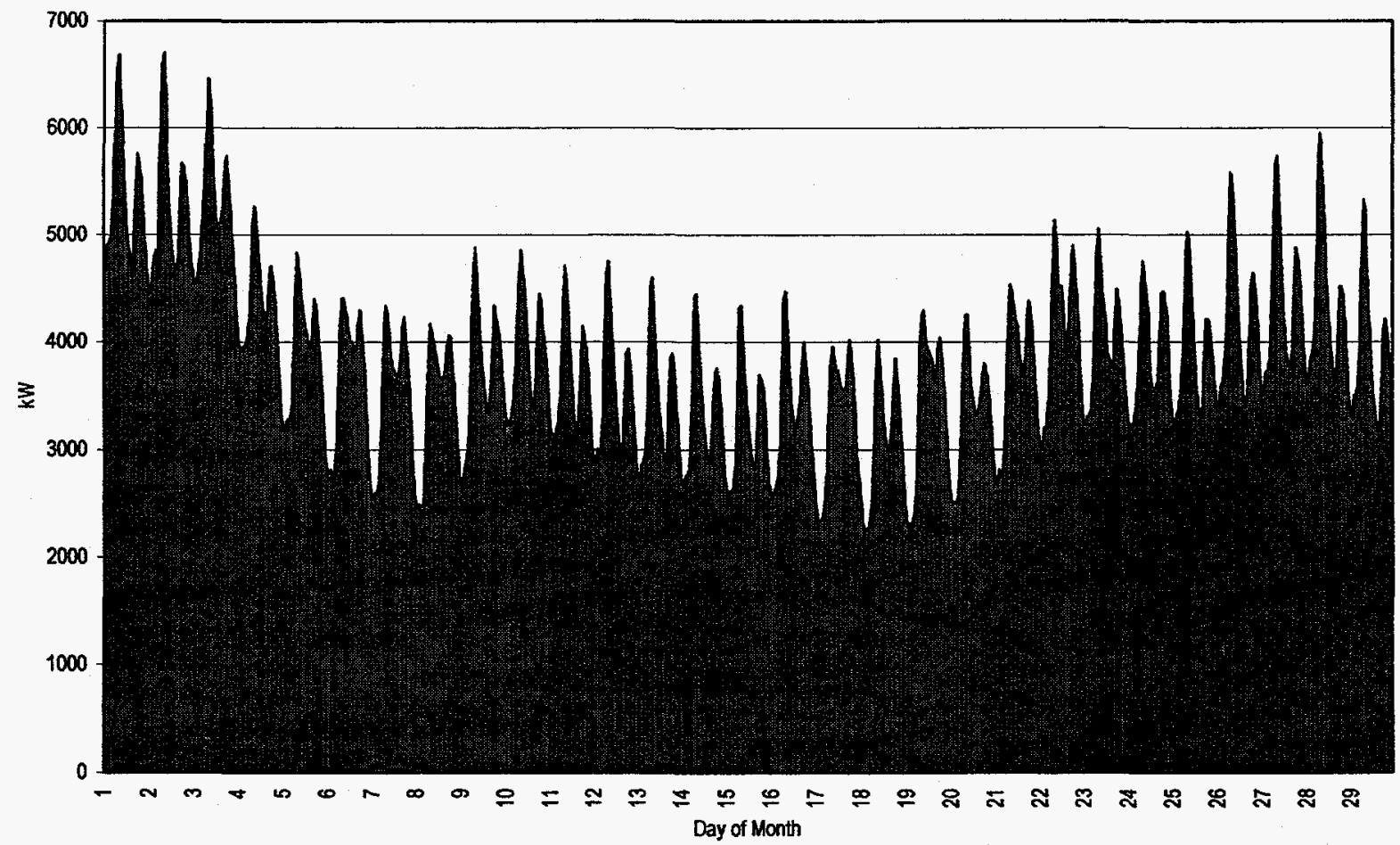

Figure A.4. Hourly Eastsound load-February 1996 


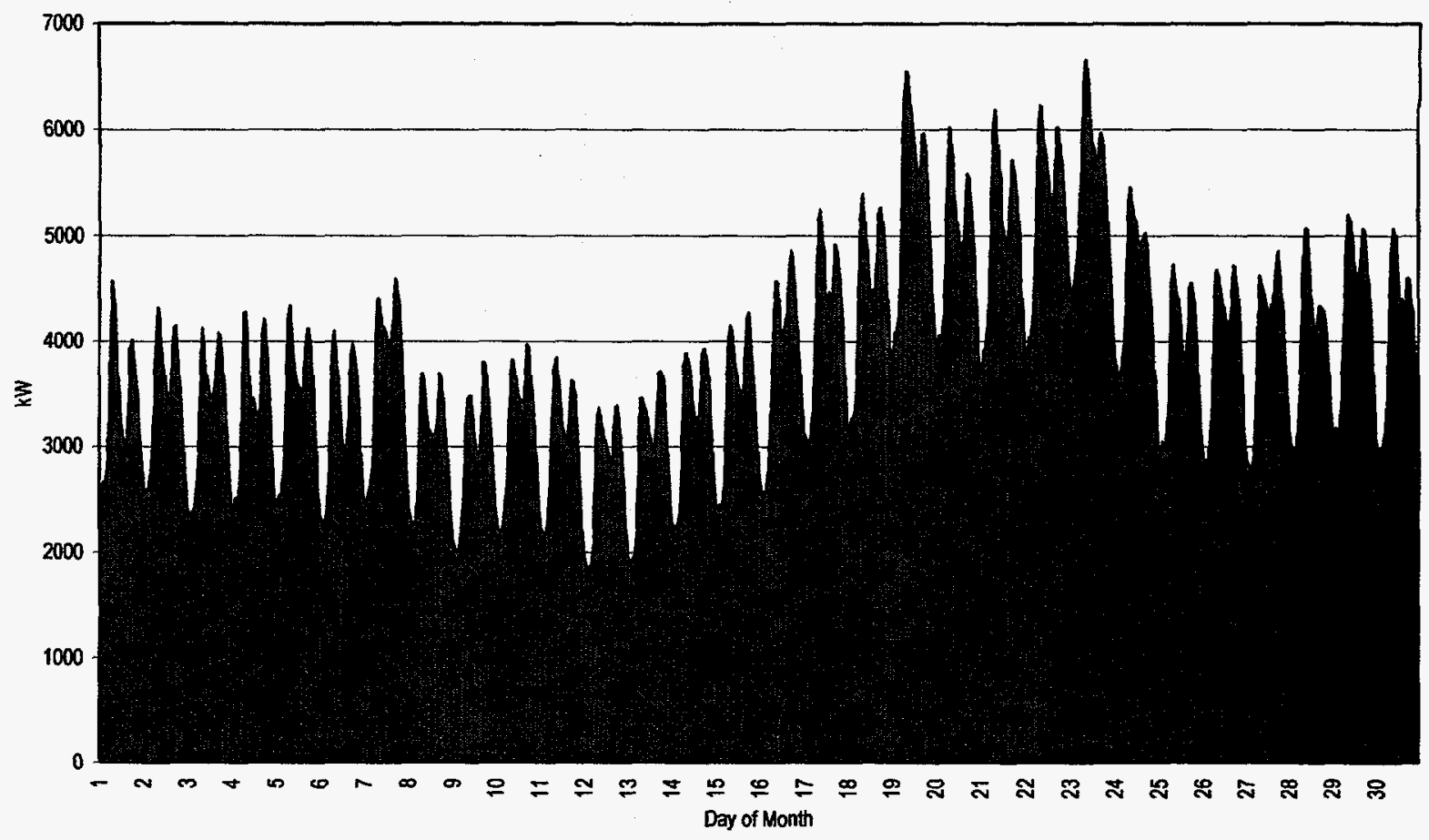

Figure A.5. Hourly Eastsound load-November 1996

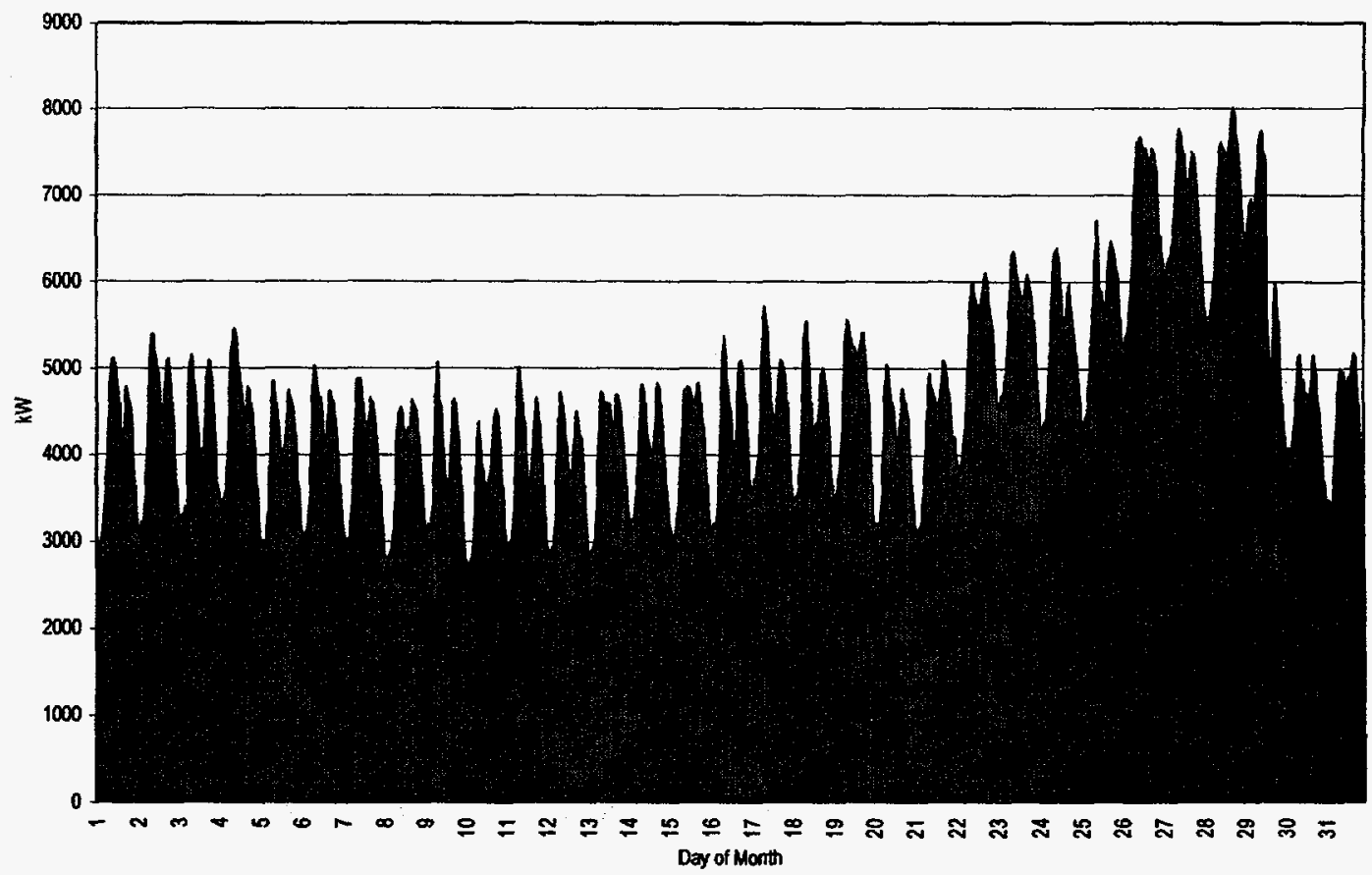

Figure A.6. Hourly Eastsound load—December 1996 


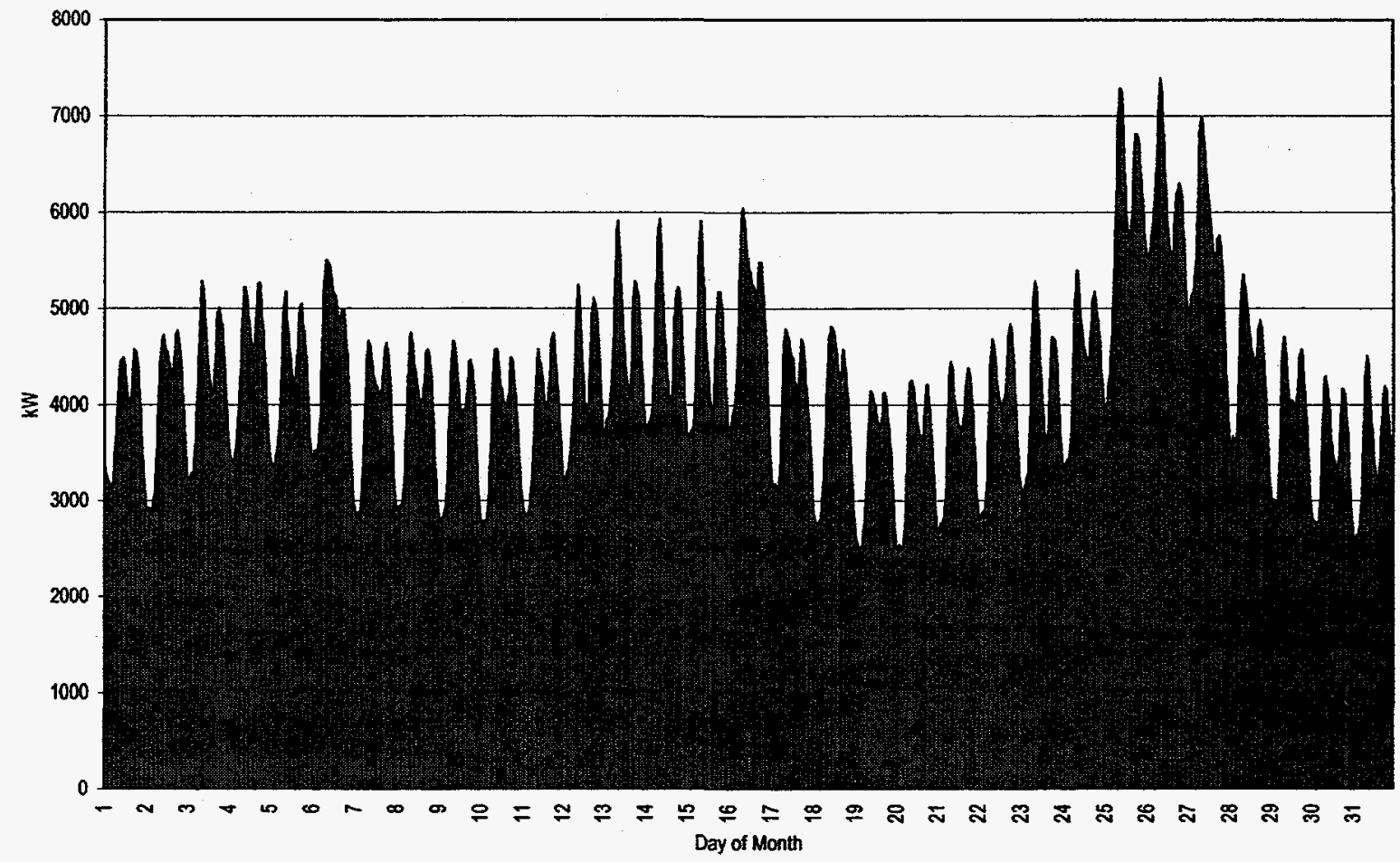

Figure A.7. Hourly Eastsound load—January 1997

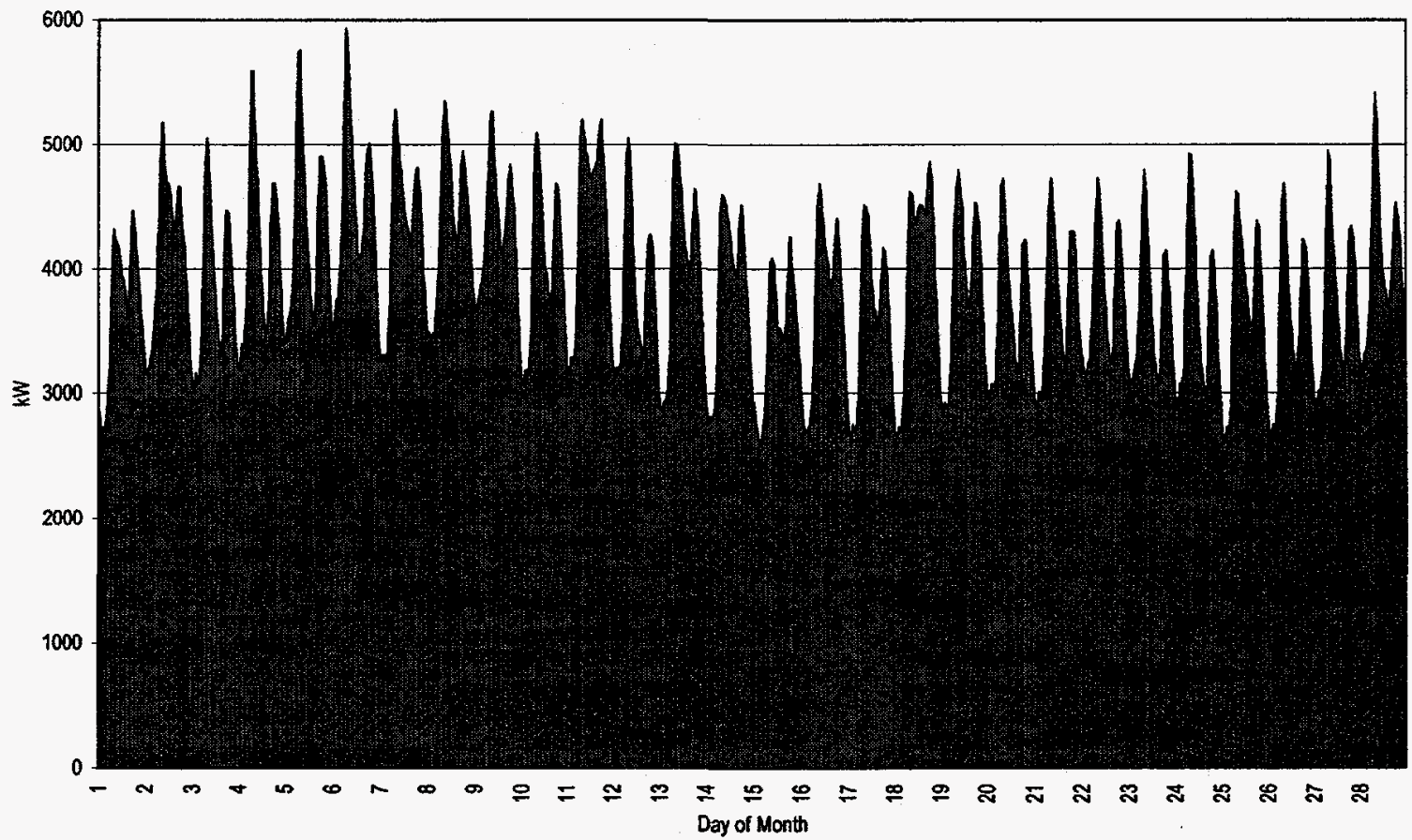

Figure A.8. Hourly Eastsound load—February 1997 


\section{APPENDIX B}

\section{HOURLY WIND AND MW-SCALE WIND PLANT PERFORMANCE- MT. CONSTITUTION 163 FT. (49.6 m)}

Hourly wind data were collected near the top of the Mt. Constitution site at $163 \mathrm{ft}$. $(469.6 \mathrm{~m})$ and at $120 \mathrm{ft}$. (36.5 m) above the ground. Figures B.1 through B.8 present the hourly winds and resulting hourly MW-scale wind plant performance monthly during the 1995-1996 winter peak season from November 1995 through February 1996 at the $163 \mathrm{ft}$. $(49.6 \mathrm{~m})$ level. Figures B.9 through B.16 present the hourly winds and resulting hourly MW-scale wind plant performance monthly during the 1996-1997 winter peak season from November 1996 through February 1997 at the $163 \mathrm{ft}$. $(49.6 \mathrm{~m})$ level. Hourly MWscale wind plant performance is derived assuming the wind data collected during the study period, two $750-\mathrm{kW}$ variable-speed wind turbines, and the wind-power curve presented in Figure 3.

Some wind data were lost from January 21 to January 28, 1996; from February 22 to February 25, 1996; from December 24 to December 27, 1996; and from January 24, 1997 to February 3, 1997. These data appear to have been lost because of anemometer icing. 


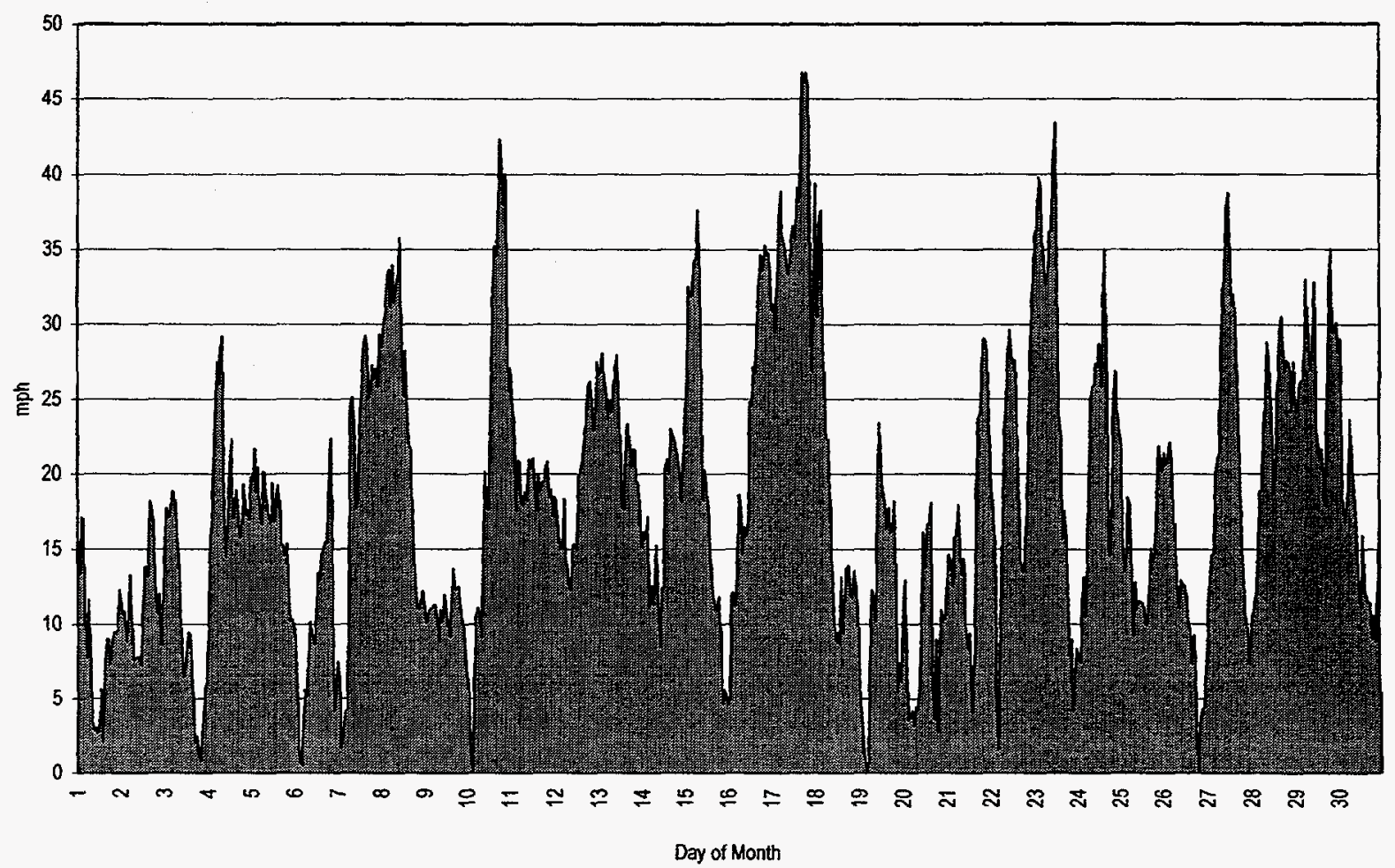

Figure B.1. Hourly wind speed at $163 \mathrm{ft} .(49.6 \mathrm{~m})$ in November 1995

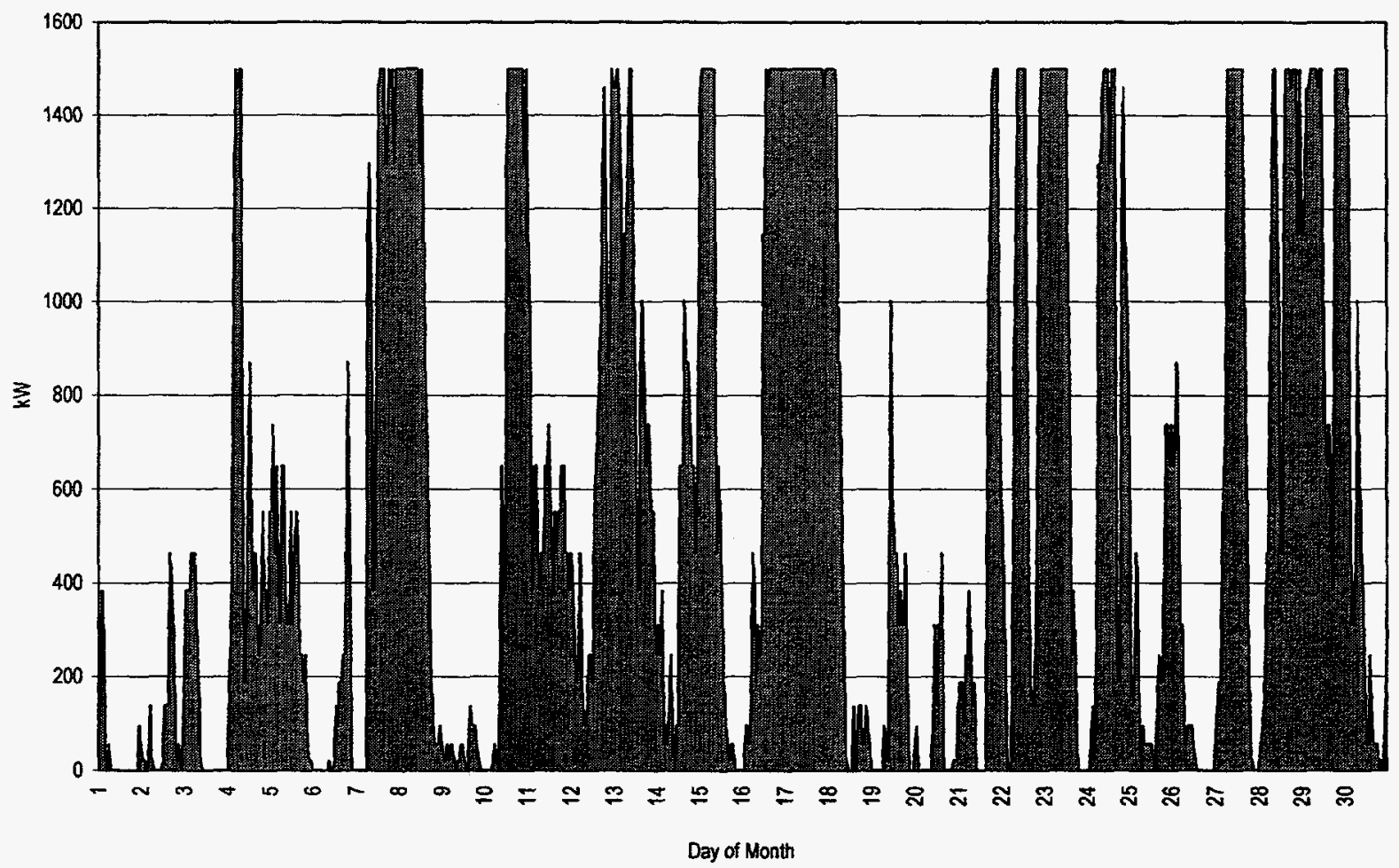

Figure B.2. Hourly 1.5-MW wind farm performance in November $1995-163 \mathrm{ft} .(49.6 \mathrm{~m})$ winds 


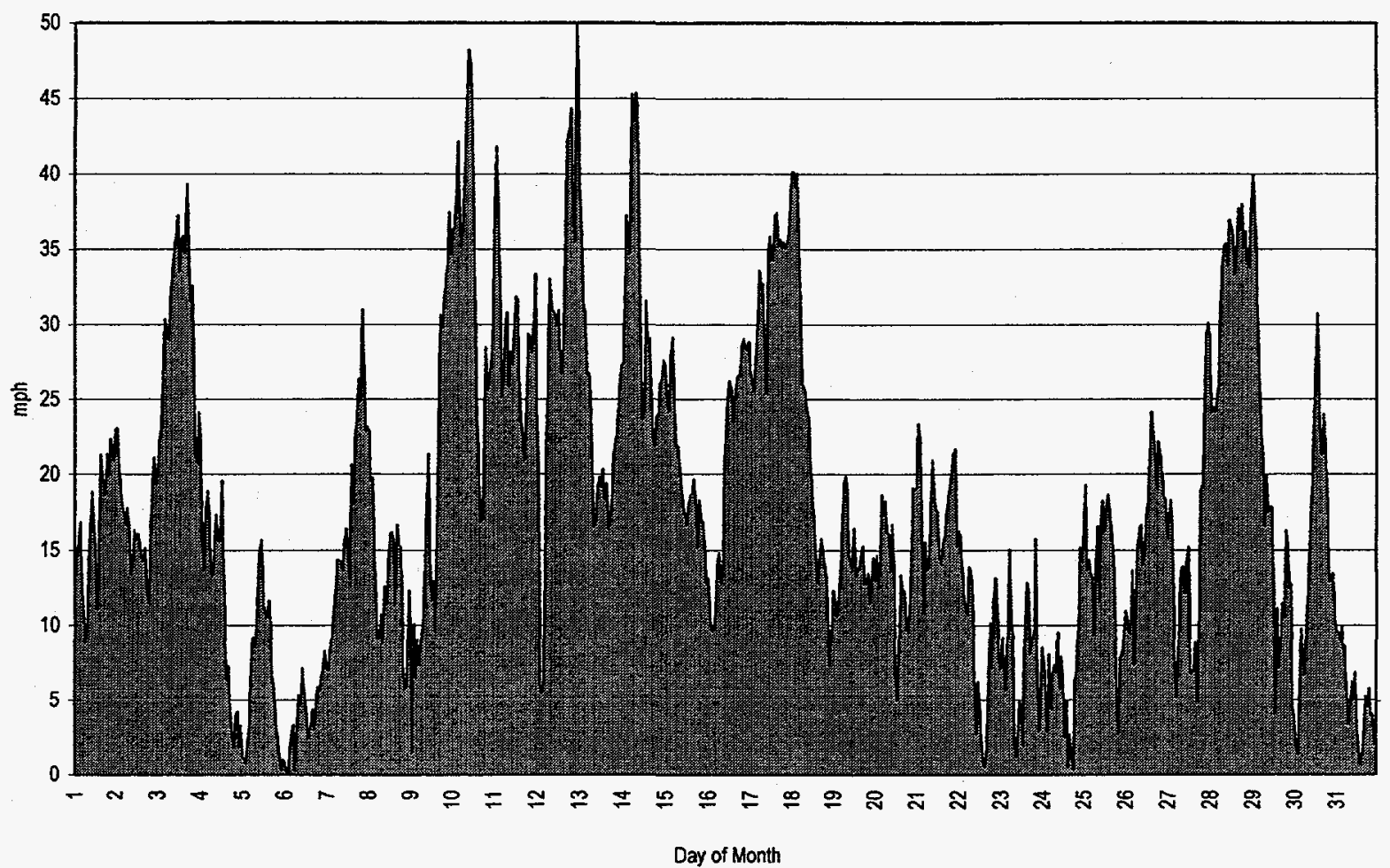

Figure B.3. Hourly wind speed at $163 \mathrm{ft} .(49.6 \mathrm{~m})$ in December 1995

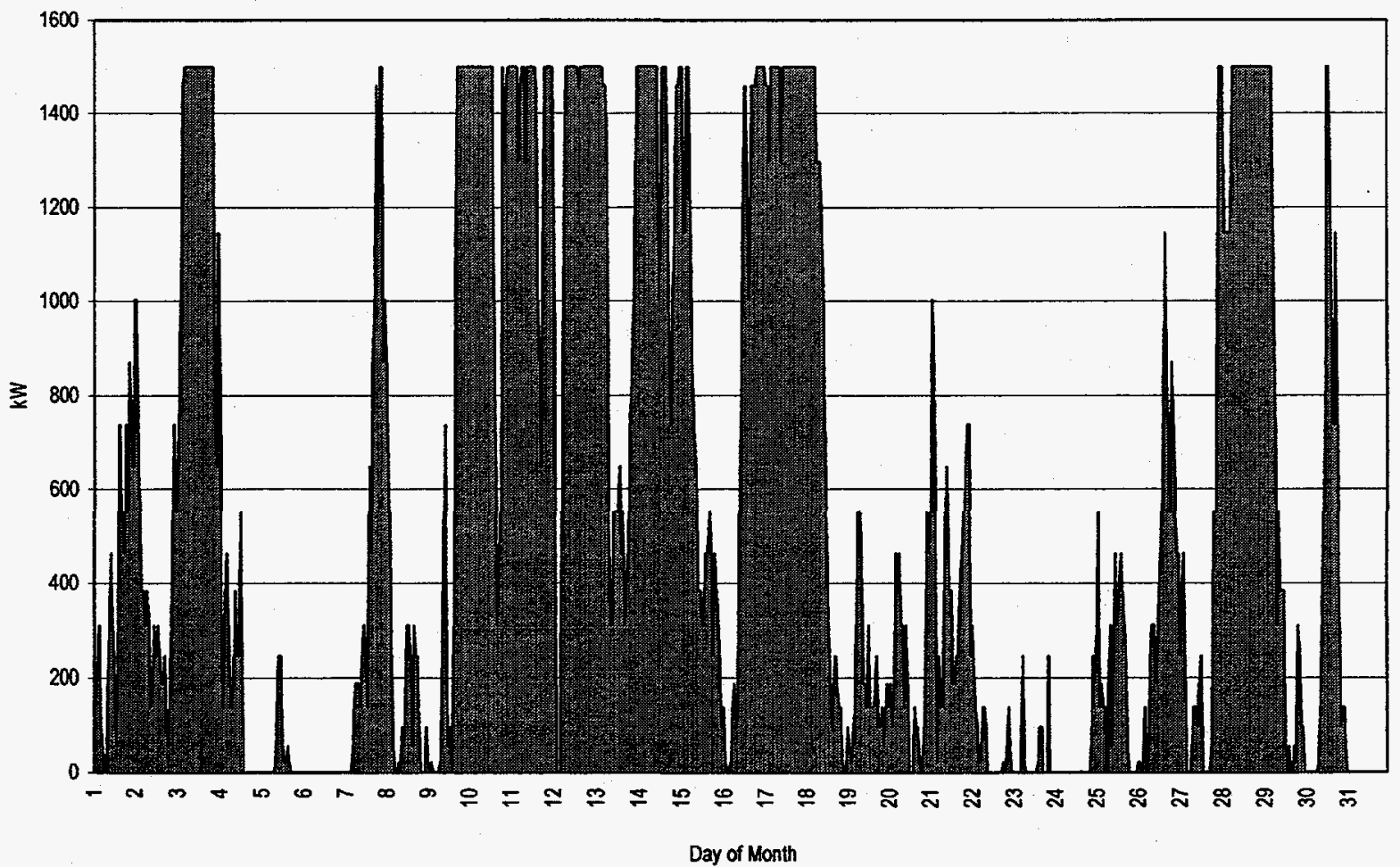

Figure B.4. Hourly 1.5-MW wind farm performance in December $1995-163 \mathrm{ft} .(49.6 \mathrm{~m})$ winds 


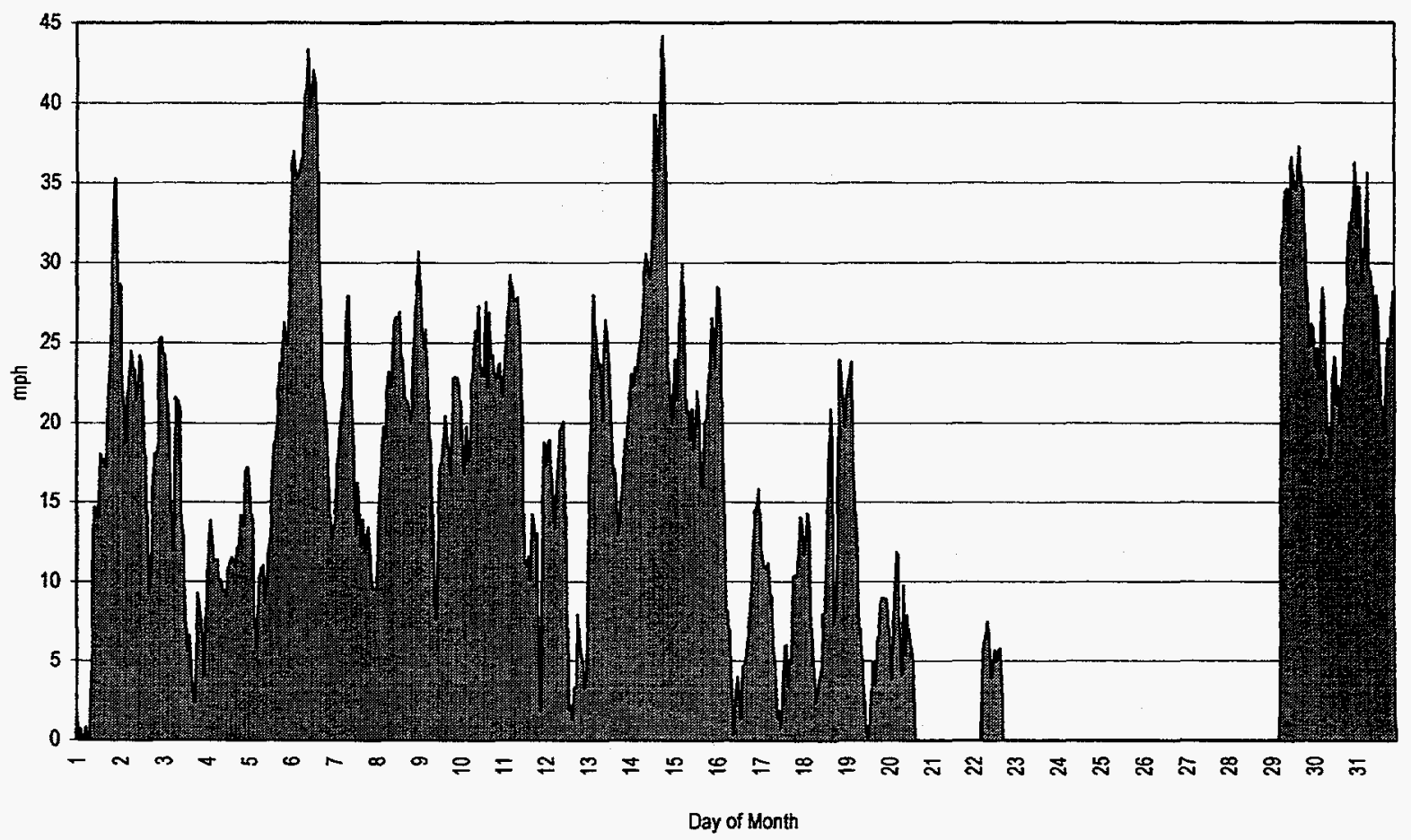

Figure B.5. Hourly wind speed at $163 \mathrm{ft} .(49.6 \mathrm{~m})$ in January 1996

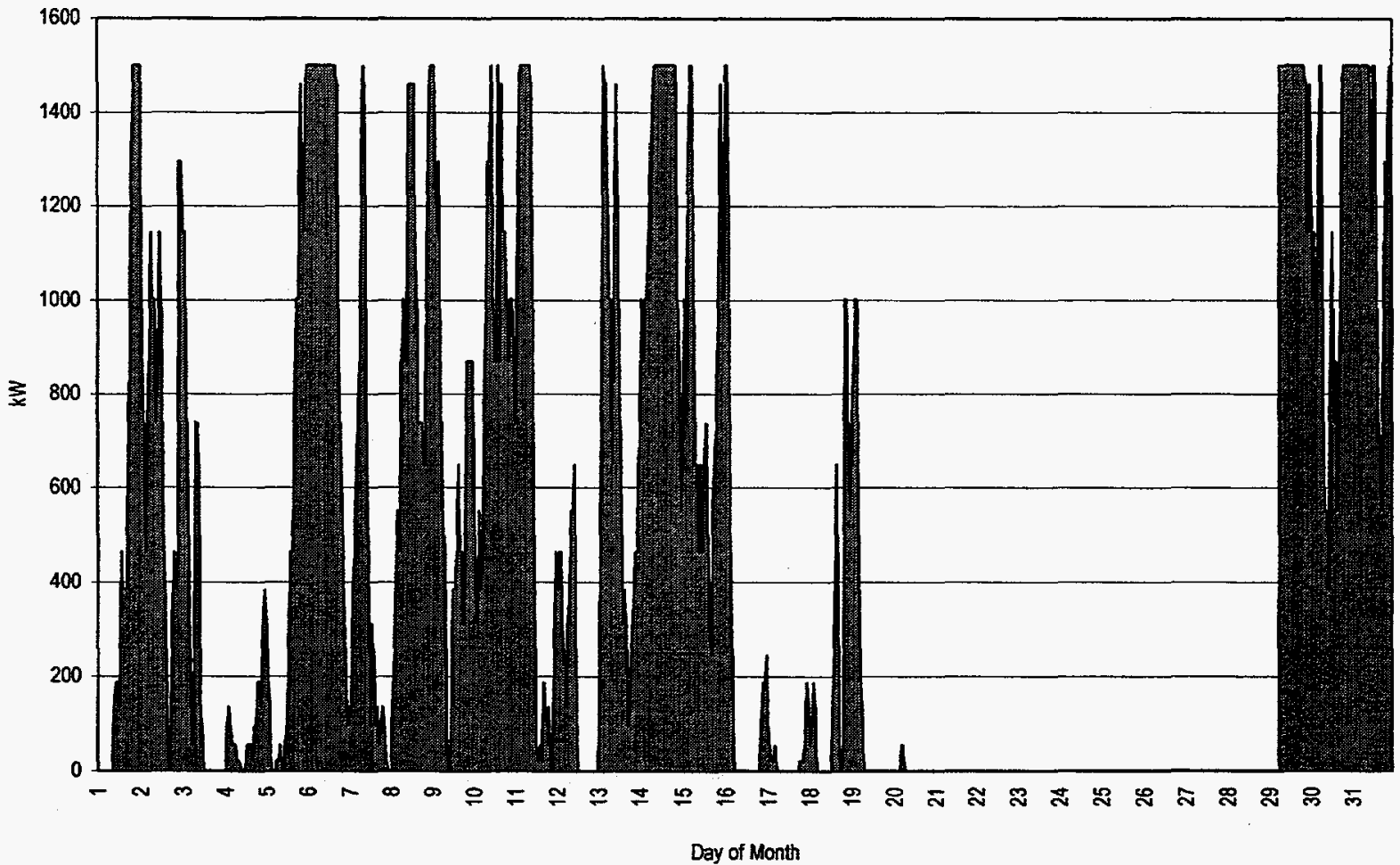

Figure B.6. Hourly 1.5-MW wind farm performance in January $1996-163 \mathrm{ft} .(49.6 \mathrm{~m})$ winds 


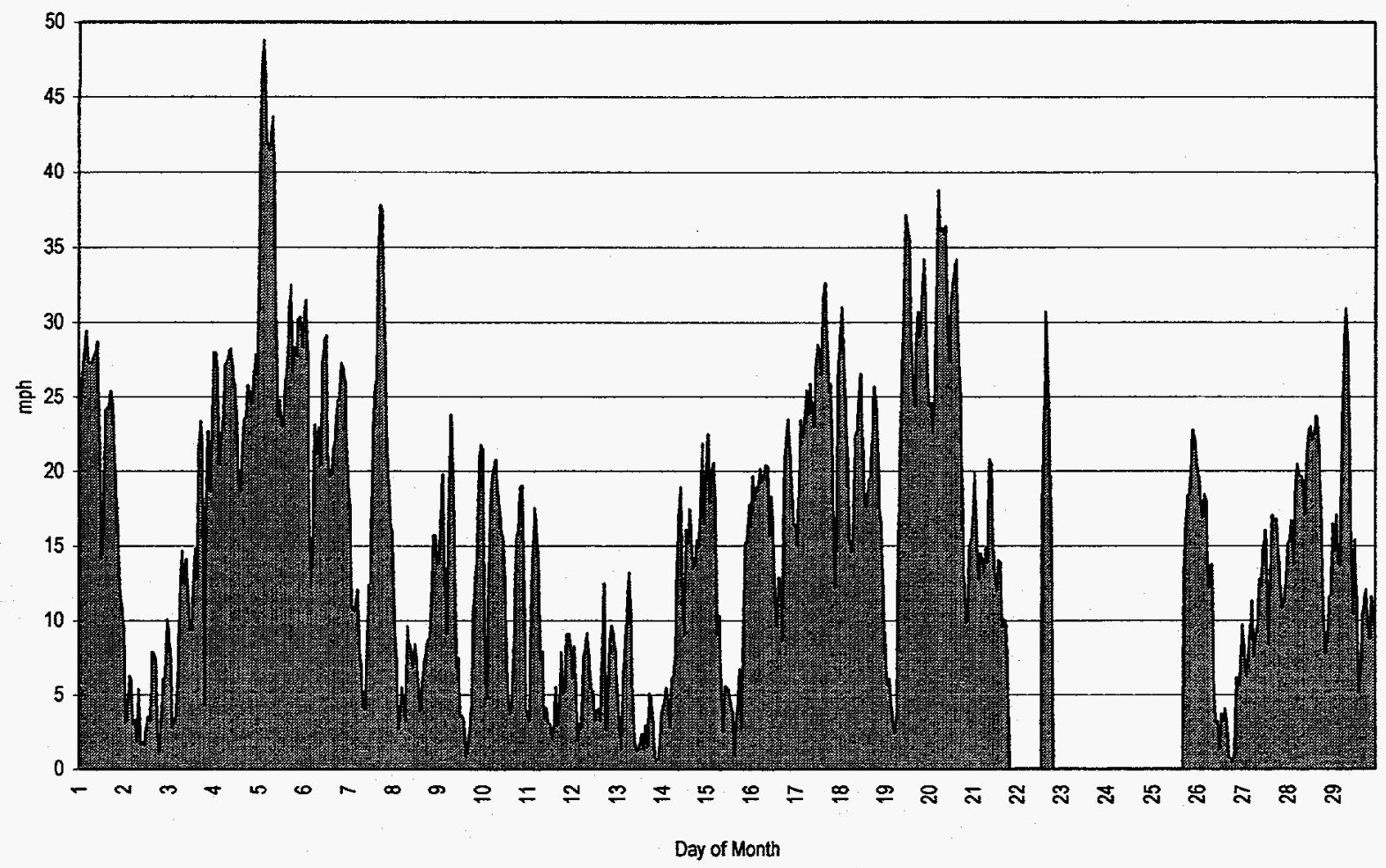

Figure B.7. Hourly wind speed at $163 \mathrm{ft} .(49.6 \mathrm{~m})$ in February 1996

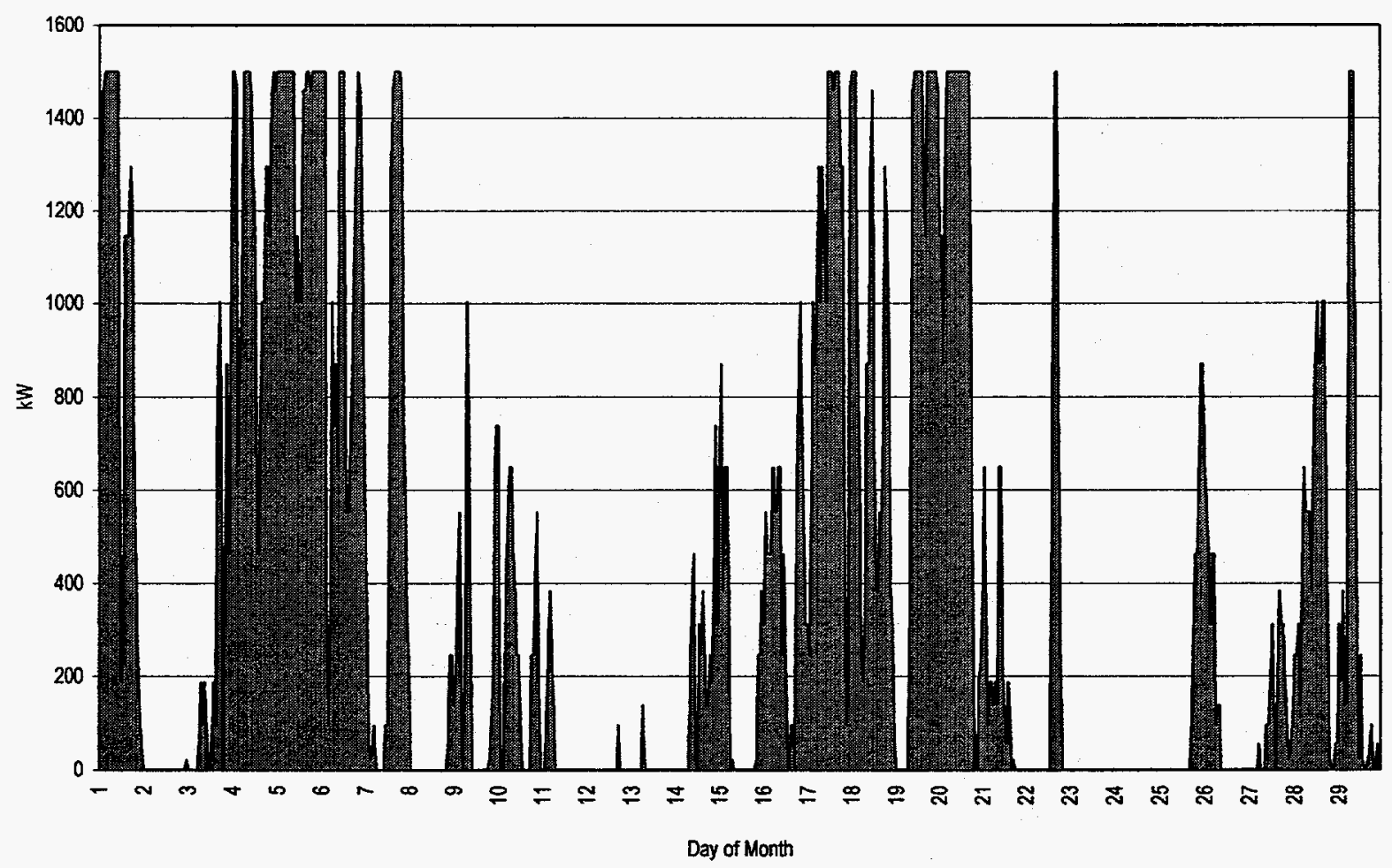

Figure B.8. Hourly 1.5-MW wind farm performance in February $1996-163 \mathrm{ft} .(49.6 \mathrm{~m})$ winds 


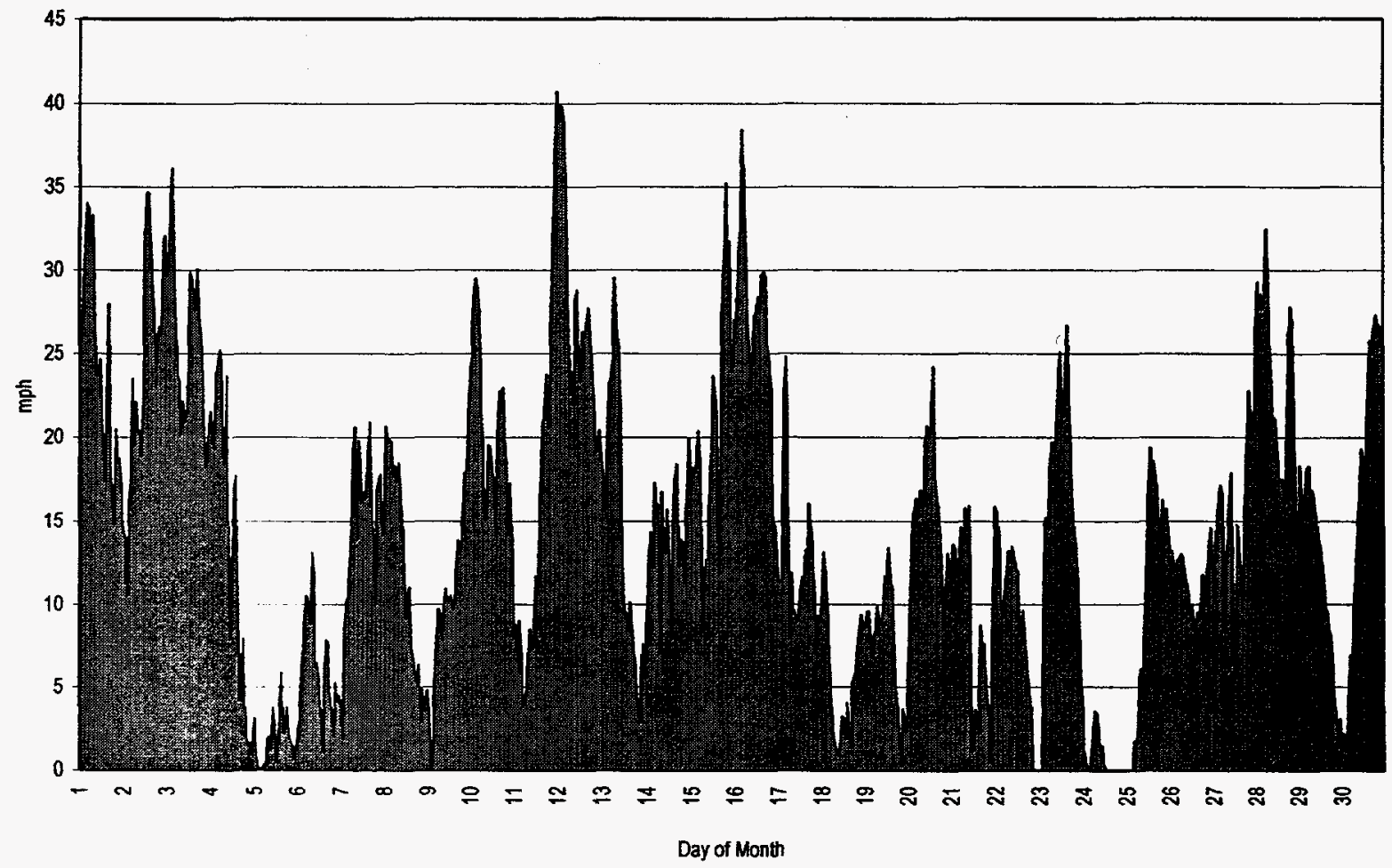

Figure B.9. Hourly wind speed at 163 ft. (49.6 m) in November 1996

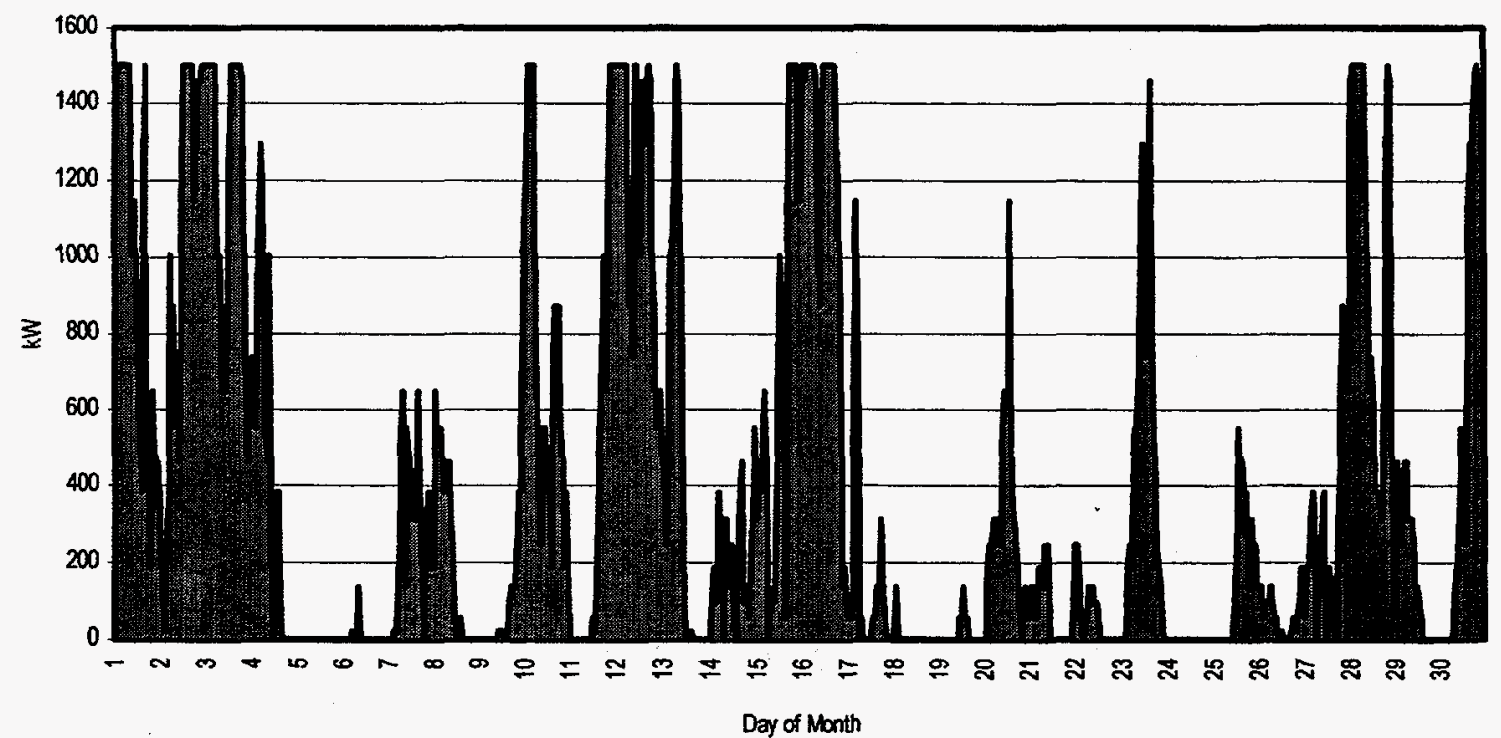

Figure B.10. Hourly 1.5-MW wind farm performance in November $1996-163 \mathrm{ft} .(49.6 \mathrm{~m})$ winds 

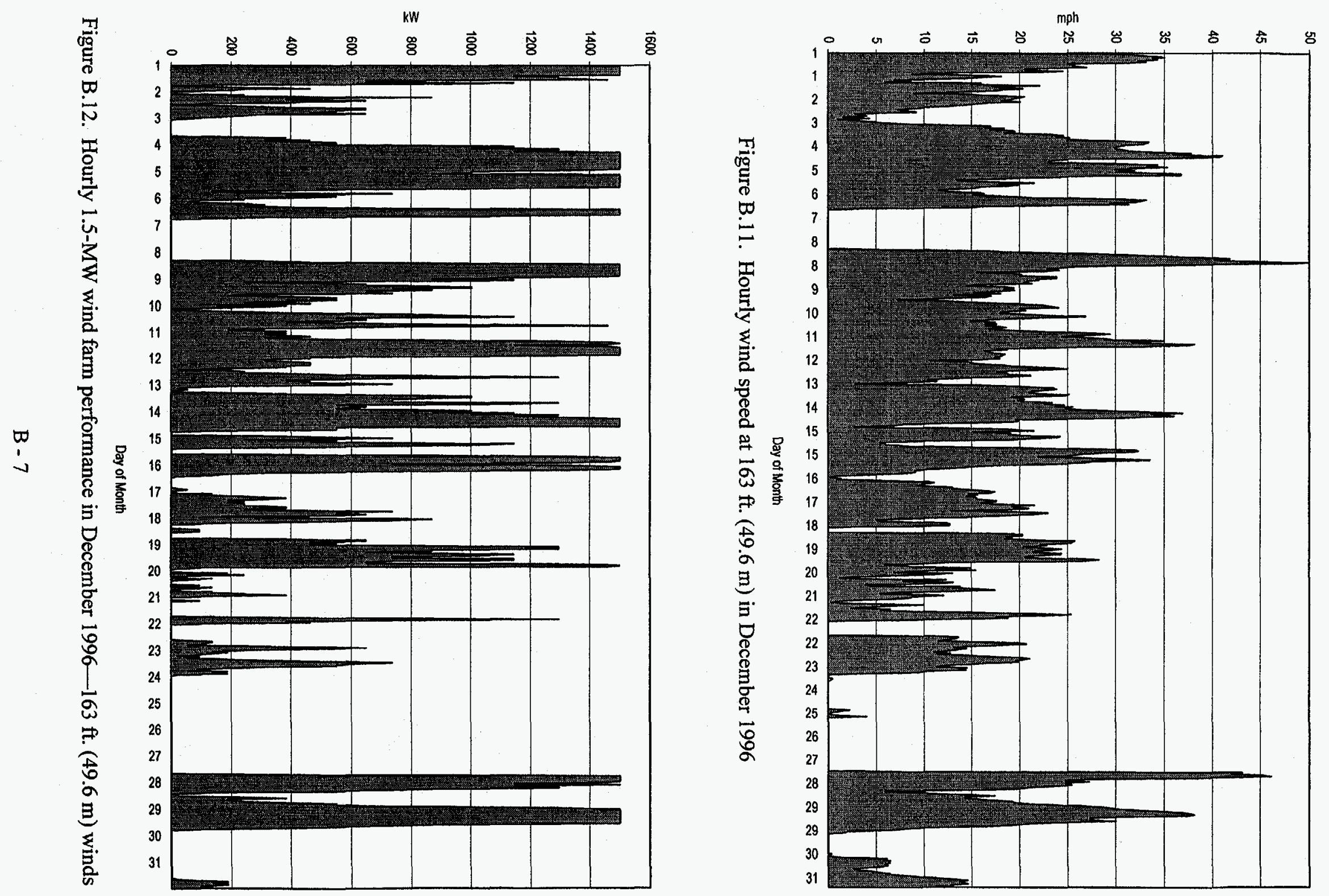


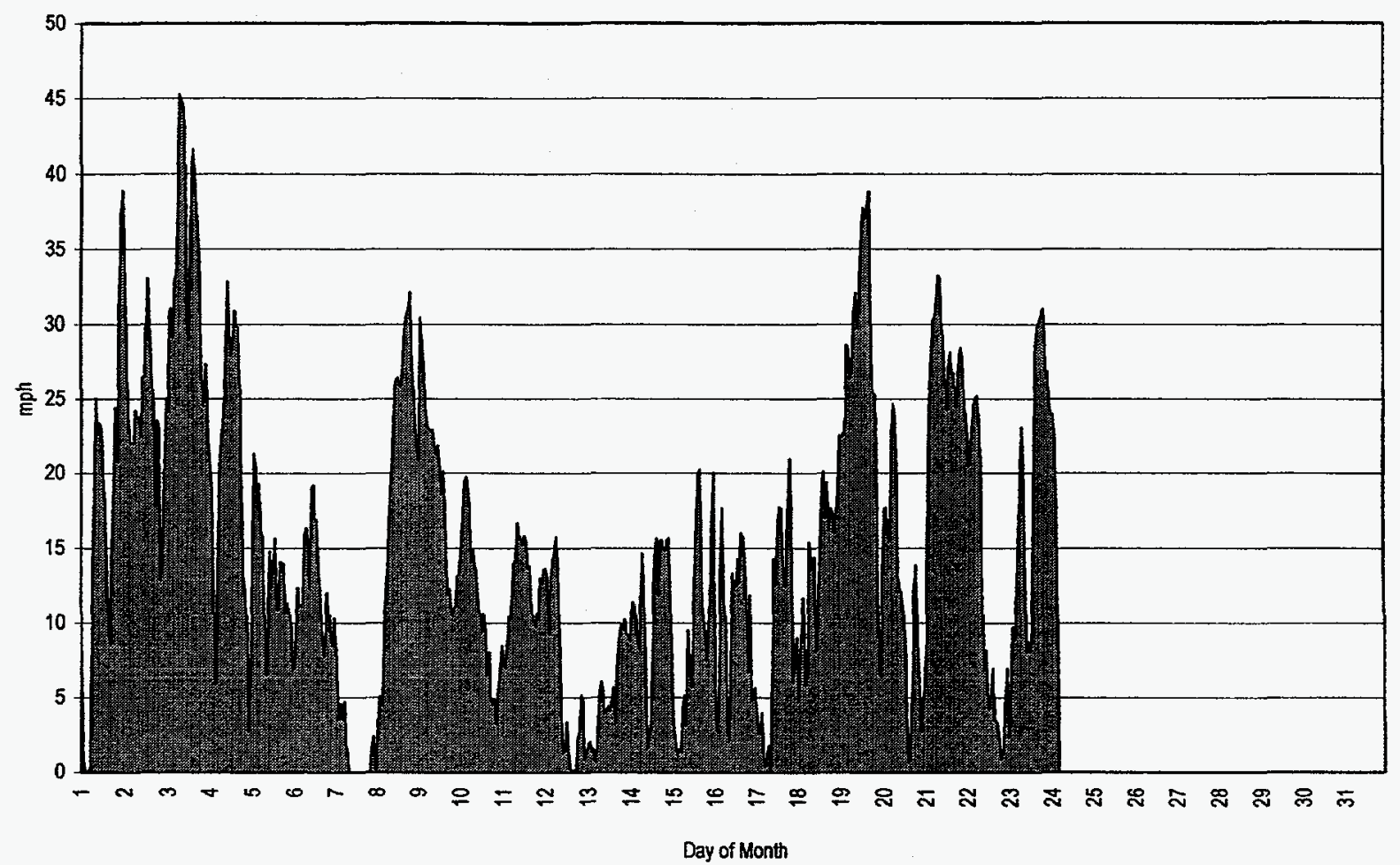

Figure B.13. Hourly wind speed at $163 \mathrm{ft}$. (49.6 m) in January 1997

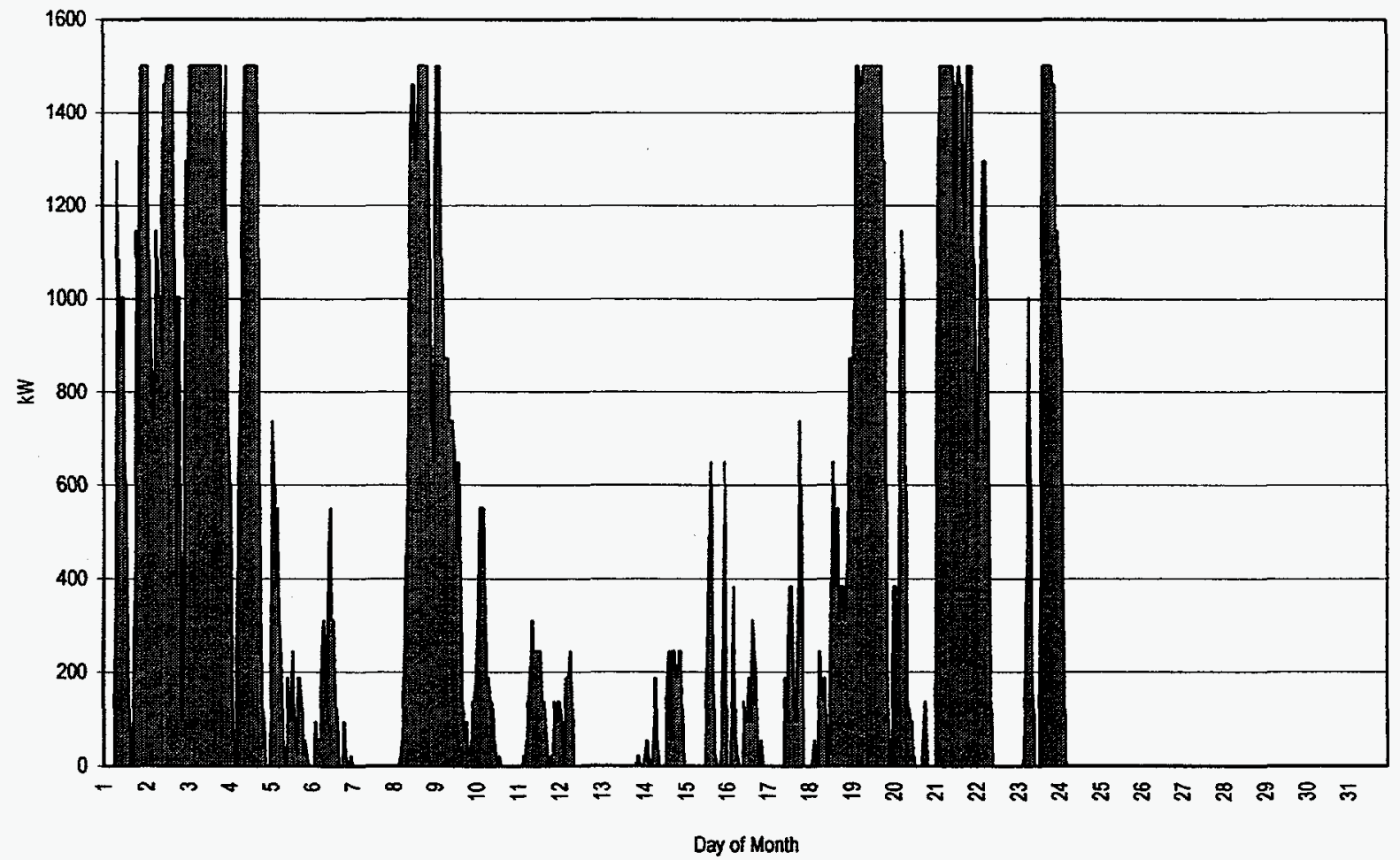

Figure B.14. Hourly 1.5-MW wind farm performance in January $1997-163 \mathrm{ft} .(49.6 \mathrm{~m})$ winds 


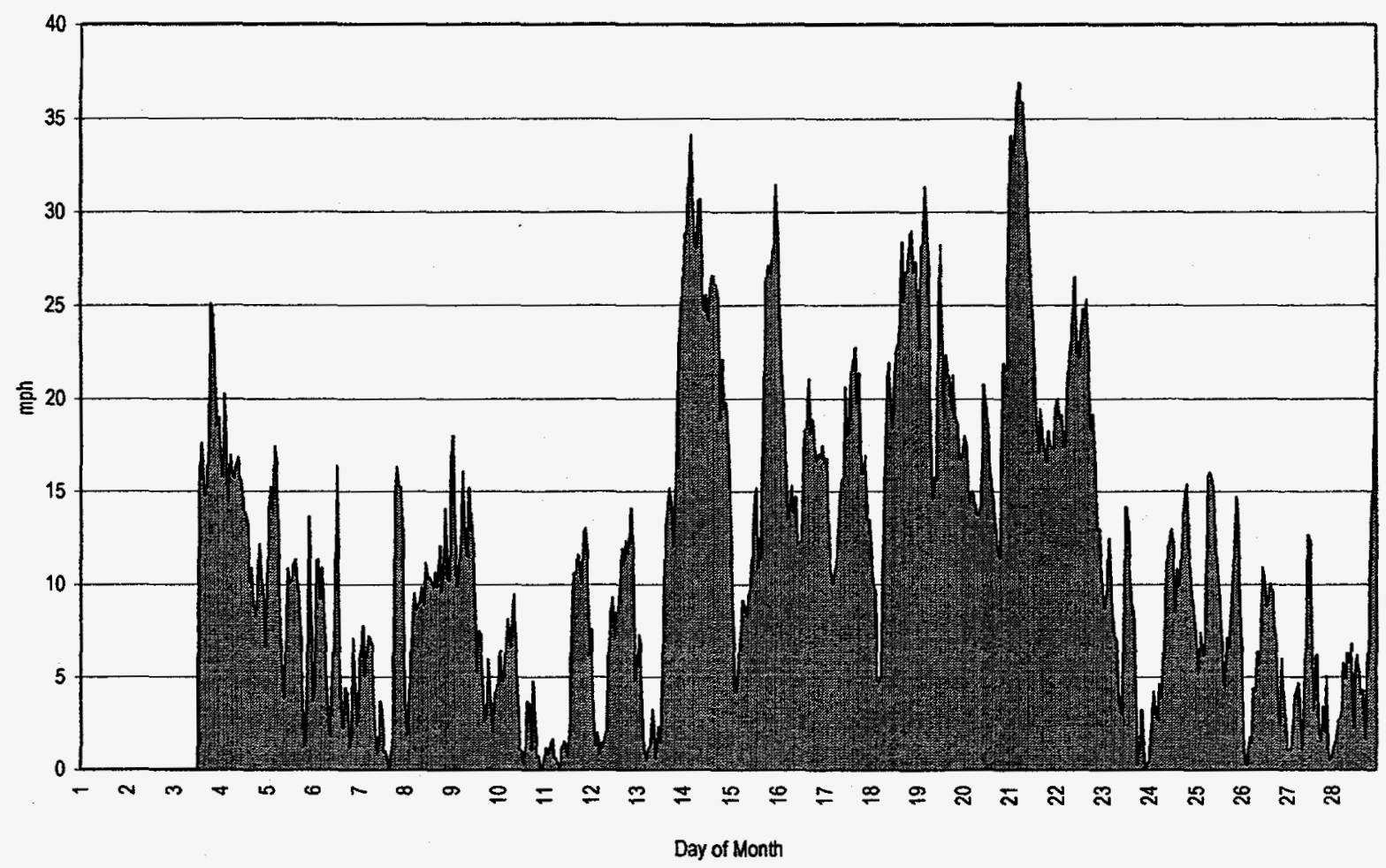

Figure B.15. Hourly wind speed at $163 \mathrm{ft} .(49.6 \mathrm{~m})$ in February 1997

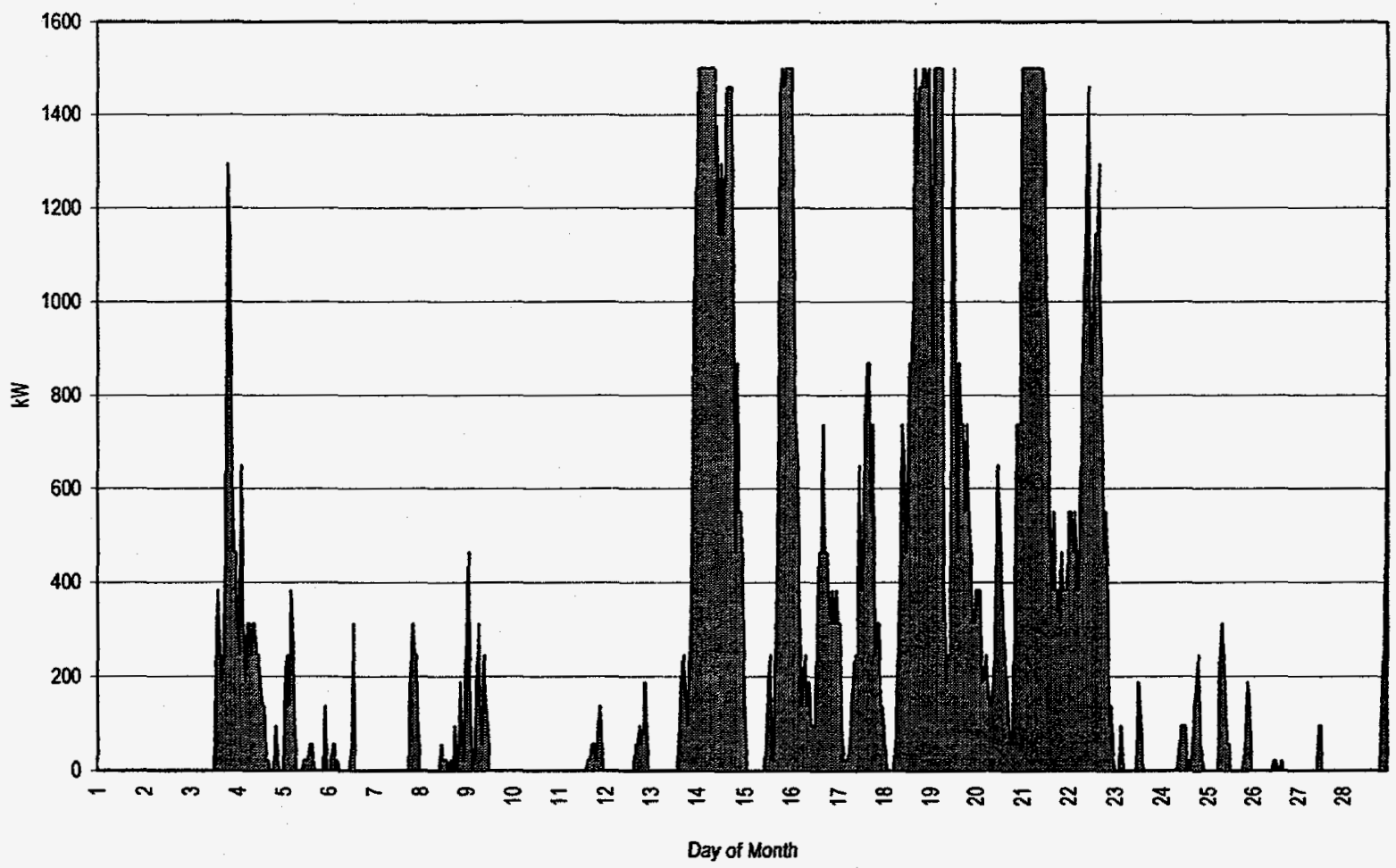

Figure B.16. Hourly 1.5-MW wind farm performance in February $1997-163 \mathrm{ft}$. (49.6 m) winds 


\section{APPENDIX C}

\section{HOURLY WIND AND MW-SCALE WIND PLANT PERFORMANCE-MT. CONSTITUTION 120 FT. (36.5 m)}

Hourly wind data were collected near the top of the Mt. Constitution site at $163 \mathrm{ft} .(49.6 \mathrm{~m})$ and at $120 \mathrm{ft}$. $(36.5 \mathrm{~m}$ ) above the ground. Figures C.1 through C.8 present the hourly winds and resulting hourly MWscale wind plant performance monthly during the 1995-1996 winter peak season from November 1995 through February 1996 at the $120 \mathrm{ft} .(36.5 \mathrm{~m})$ level. Figures C.9 through C.16 present the hourly winds and resulting hourly MW-scale wind plant performance monthly during the 1996-1997 winter peak season from November 1996 through February 1997 at the $163 \mathrm{ft}$. (49.6 m) level. Hourly MW-scale wind plant performance is derived assuming the wind data collected during the study period, two $750-\mathrm{kW}$ variable-speed wind turbines, and the wind-power curve presented in Figure 3.

Some wind data were lost from January 21 to January 28, 1996; from February 22 to February 25, 1996; from December 24 to December 27, 1996; and from January 24, 1997 to February 3, 1997. These data appear to have been lost because of anemometer icing. 


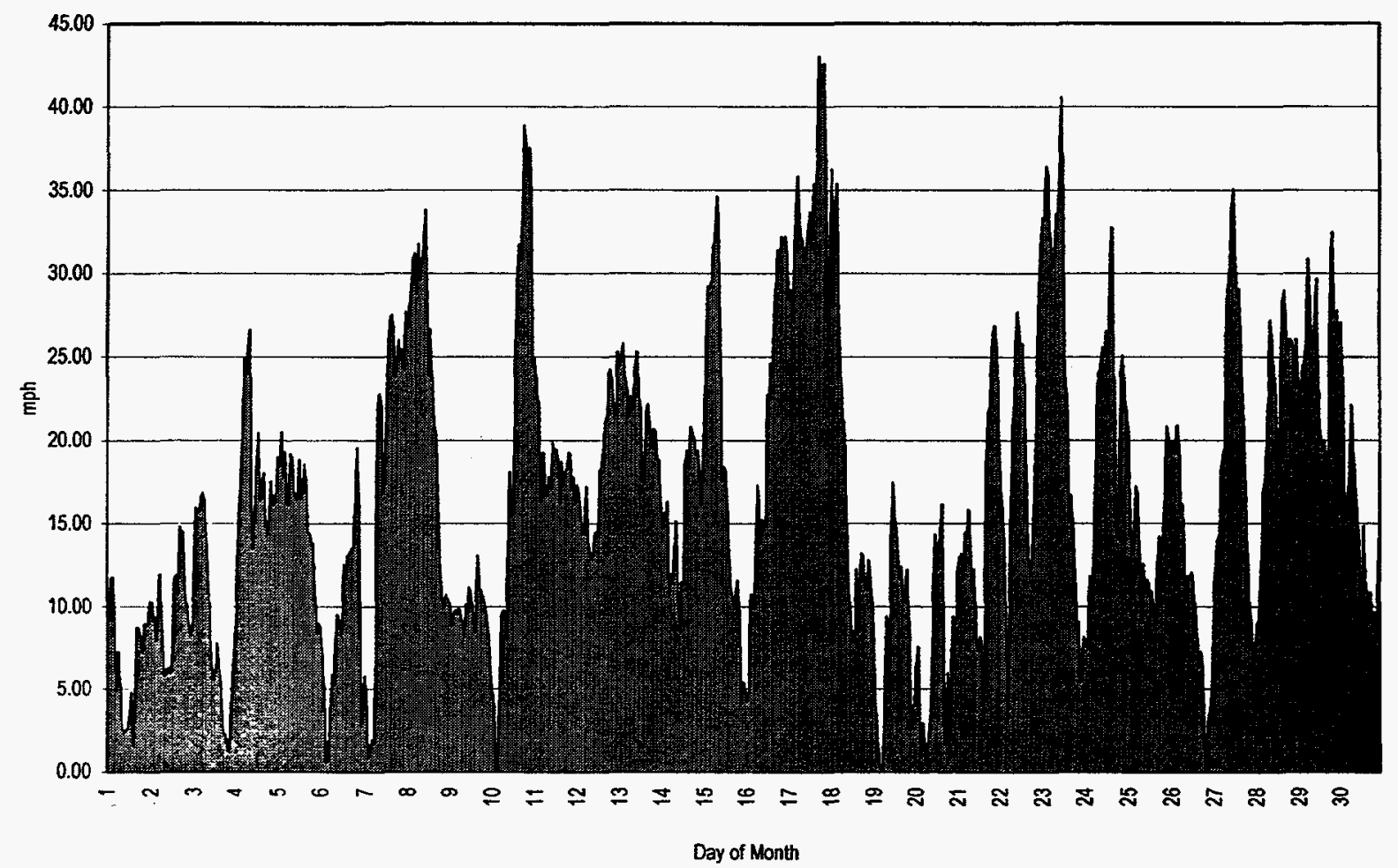

Figure C.1. Hourly wind speed at $120 \mathrm{ft} .(36.5 \mathrm{~m})$ in November 1995

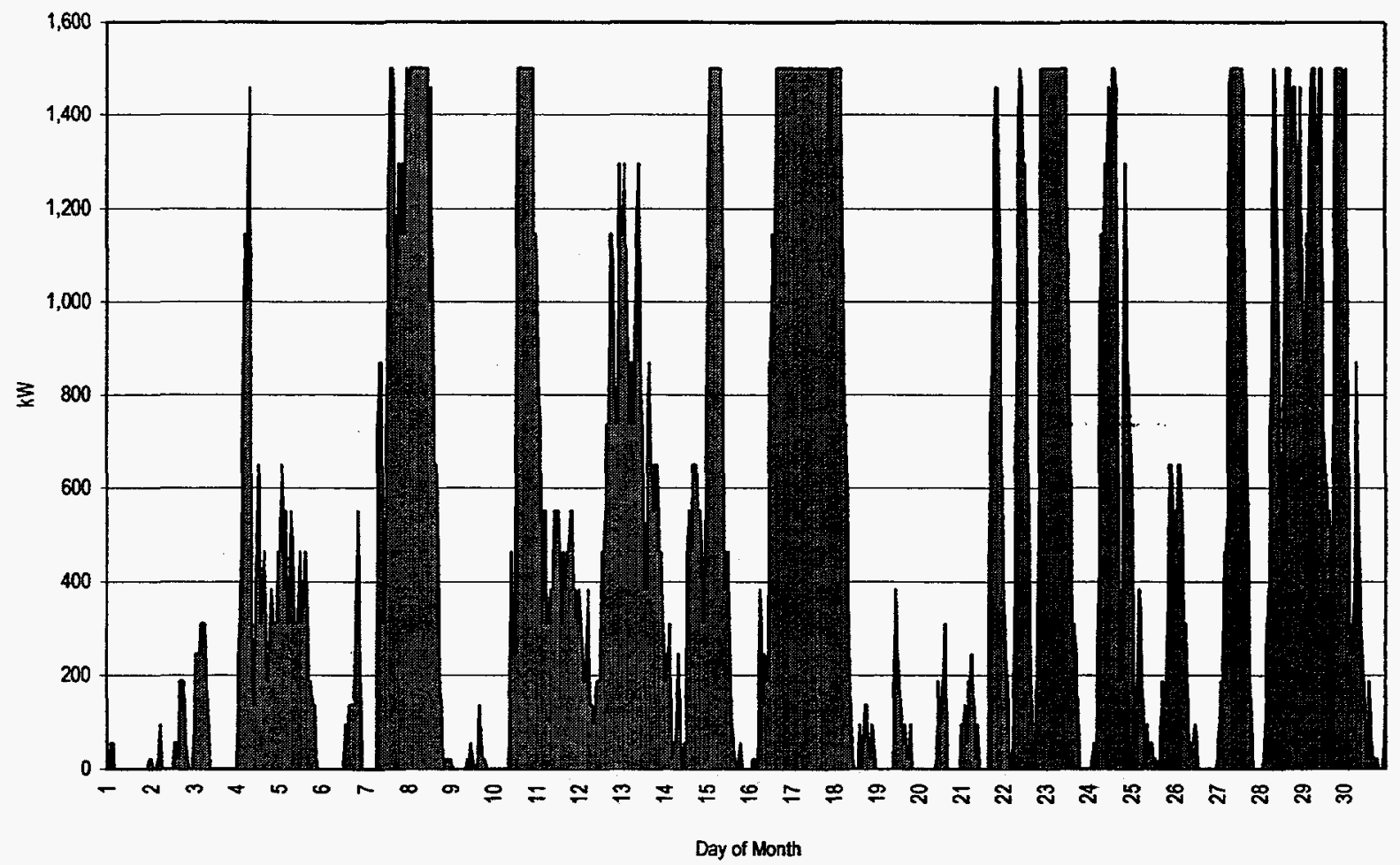

Figure C.2. Hourly 1.5-MW wind farm performance in November $1995-120 \mathrm{ft} .(36.5 \mathrm{~m})$ winds 


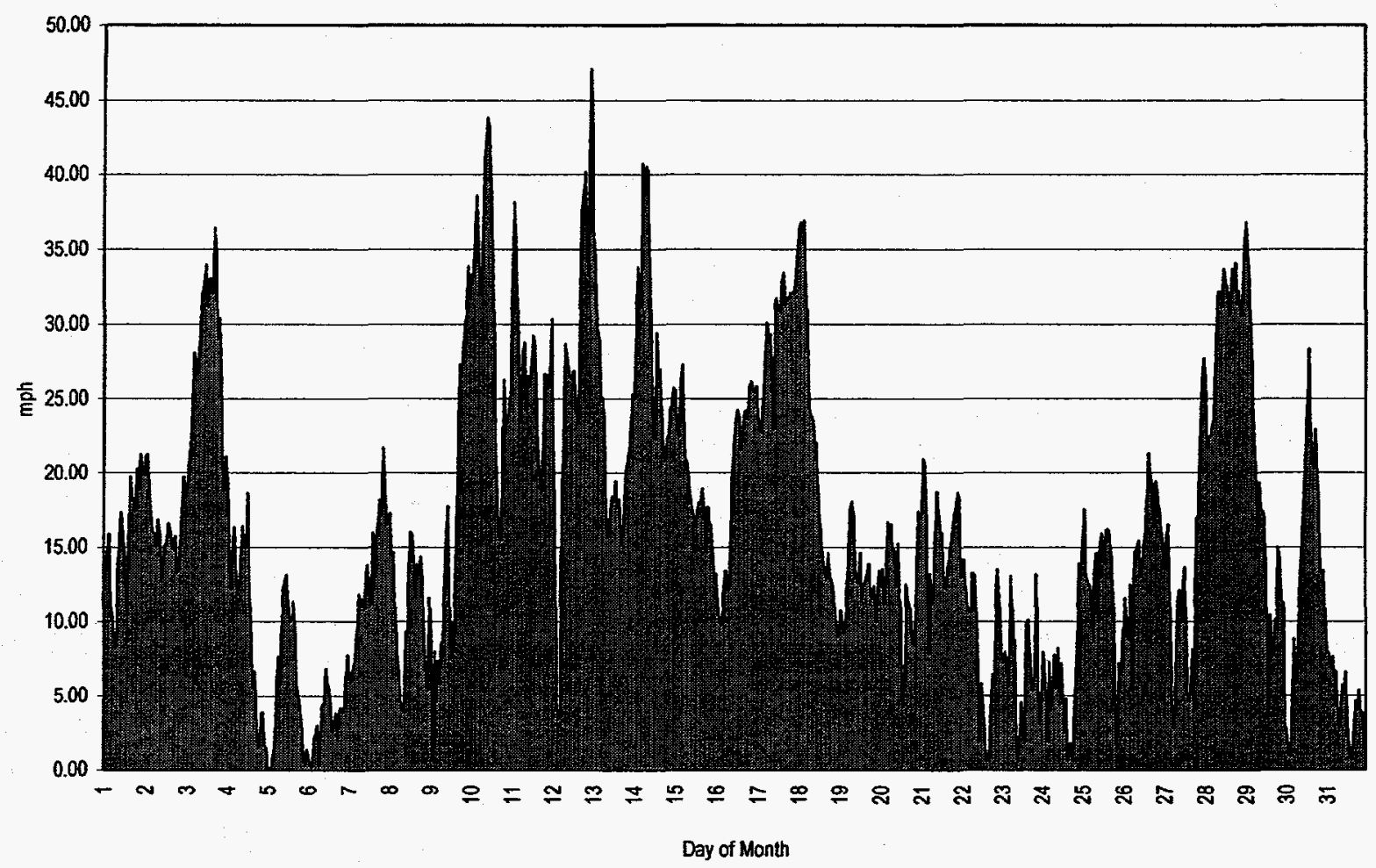

Figure C.3. Hourly wind speed at $120 \mathrm{ft} .(36.5 \mathrm{~m})$ in December 1995

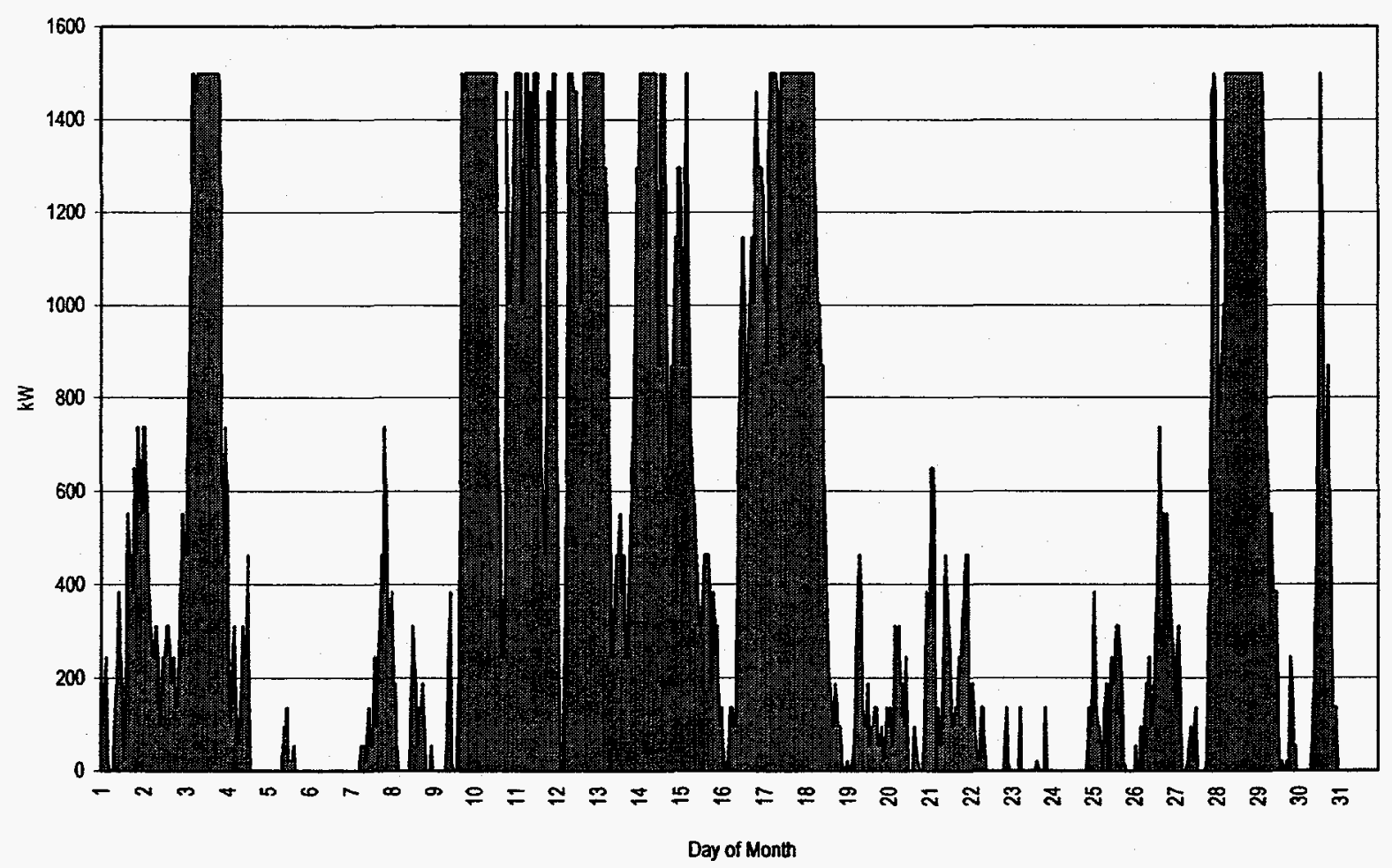

Figure C.4. Hourly 1.5-MW wind farm performance in December $1995-120 \mathrm{ft} .(36.5 \mathrm{~m})$ winds

$$
\text { C }-3
$$




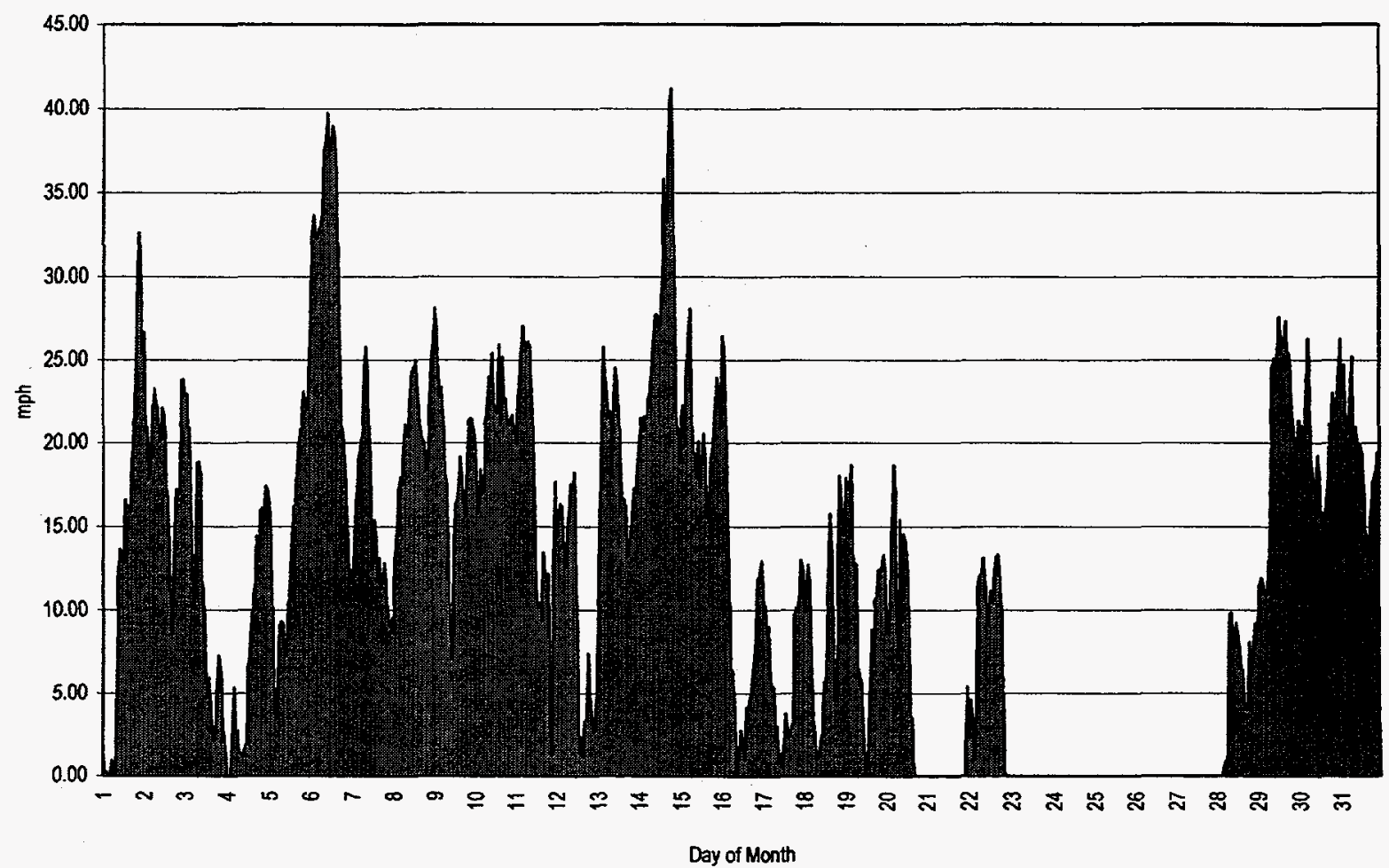

Figure C.5. Hourly wind speed at $120 \mathrm{ft} .(36.5 \mathrm{~m})$ in January 1996

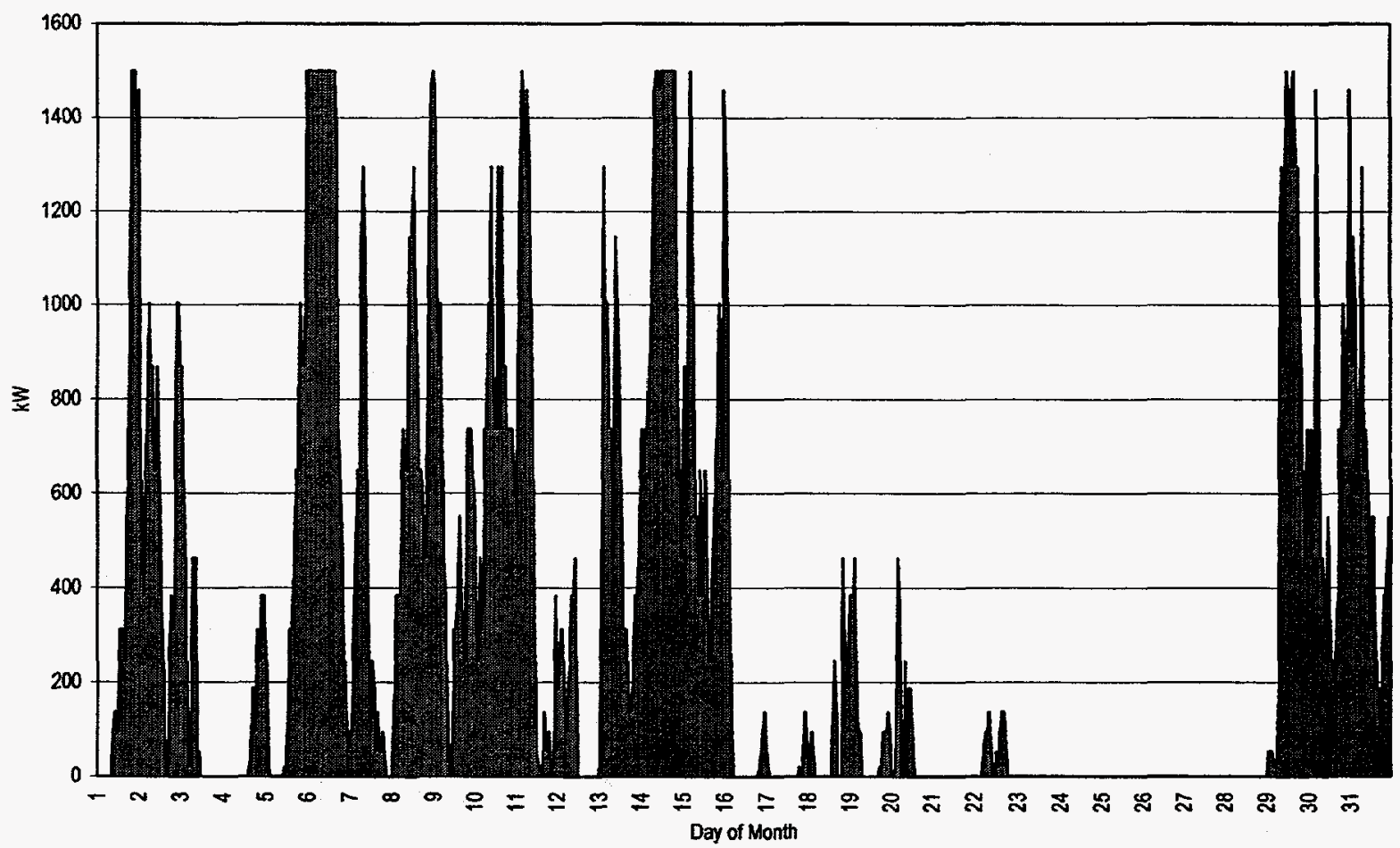

Figure C.6. Hourly 1.5-MW wind farm performance in January $1996-120 \mathrm{ft} .(36.5 \mathrm{~m})$ winds

$$
\text { C }-4
$$




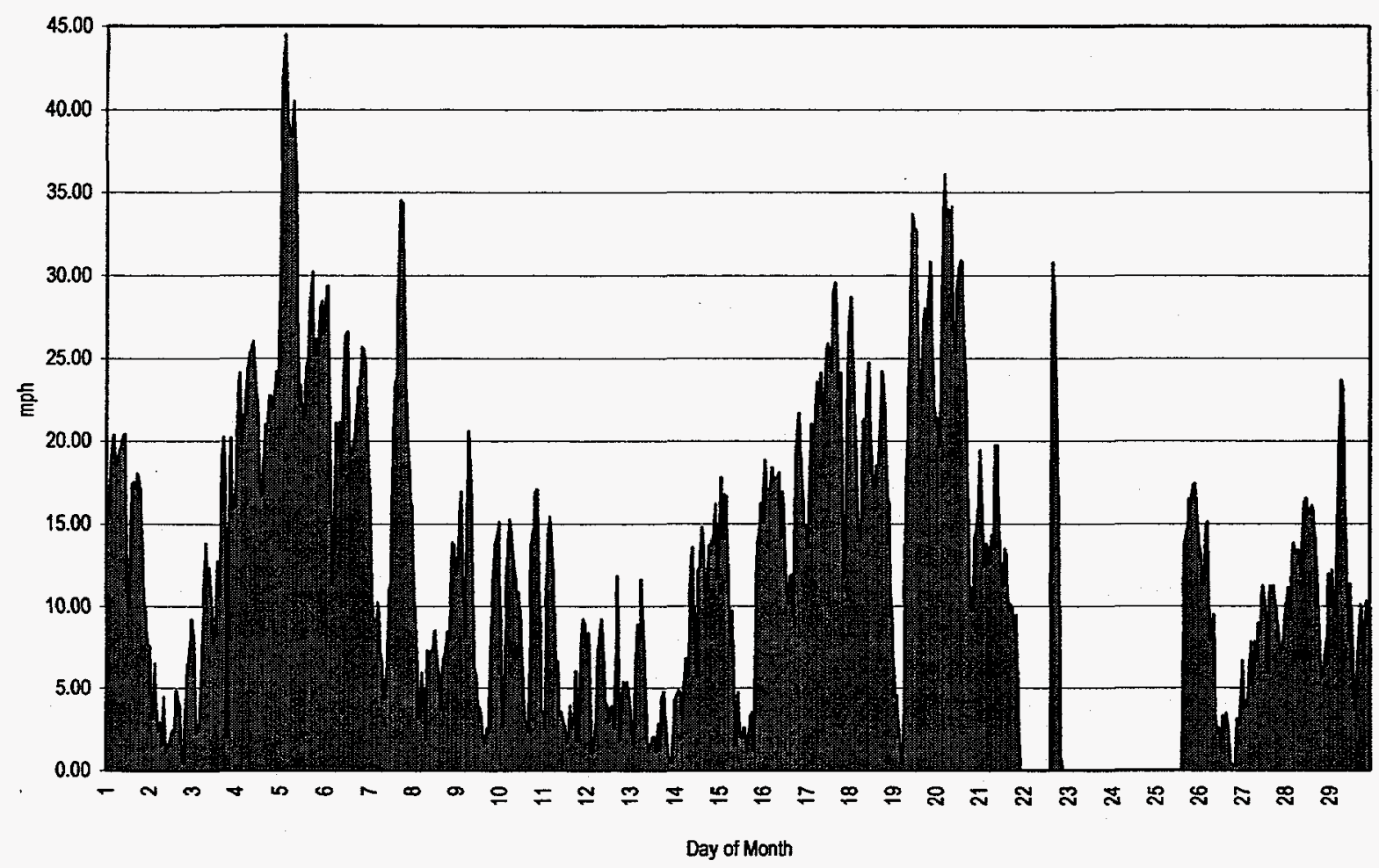

Figure C.7. Hourly wind speed at $120 \mathrm{ft} .(36.5 \mathrm{~m})$ in February 1996

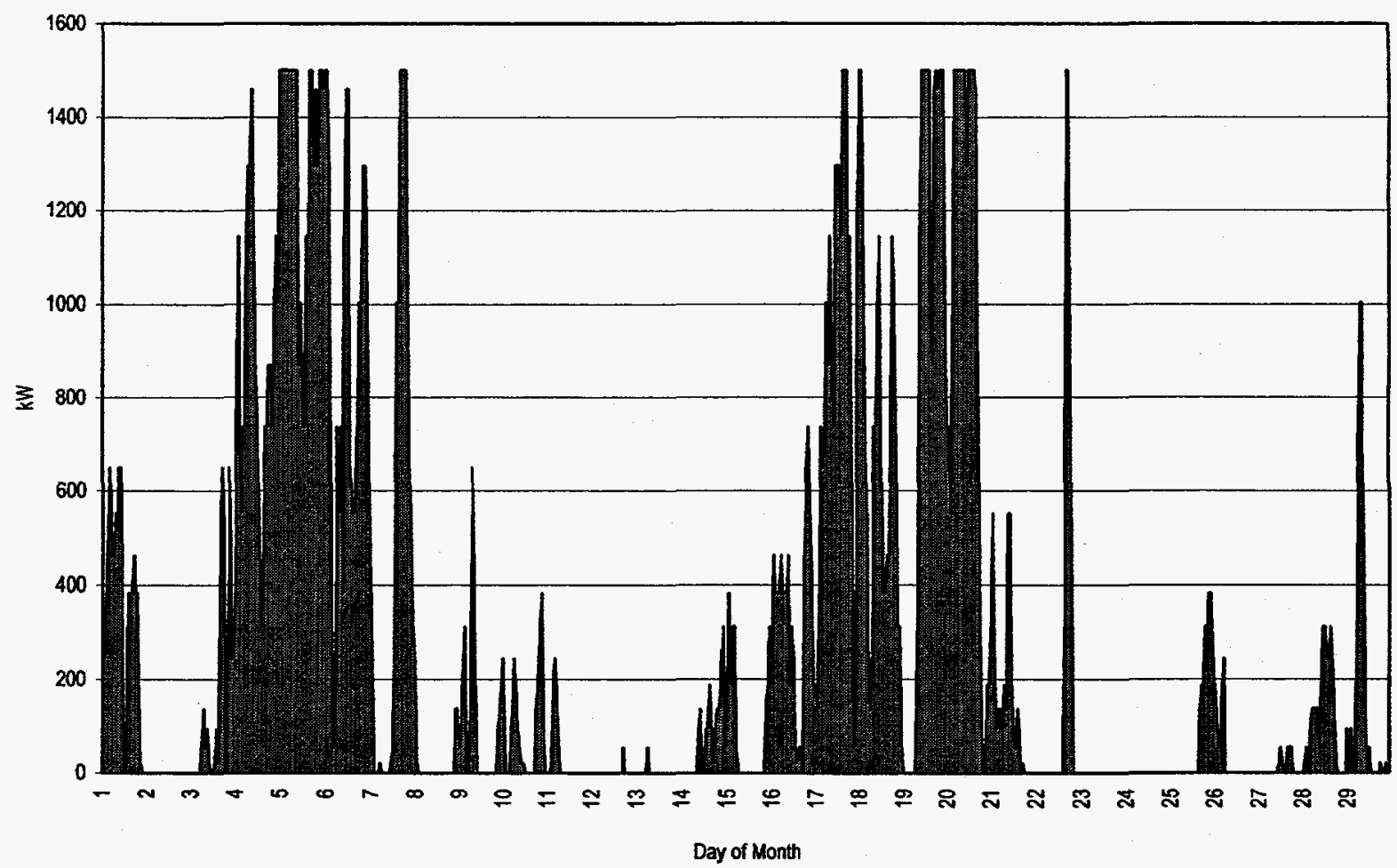

Figure C.8. Hourly 1.5-MW wind farm performance in February $1996-120 \mathrm{ft}$. (36.5 m) winds

$$
\text { C }-5
$$




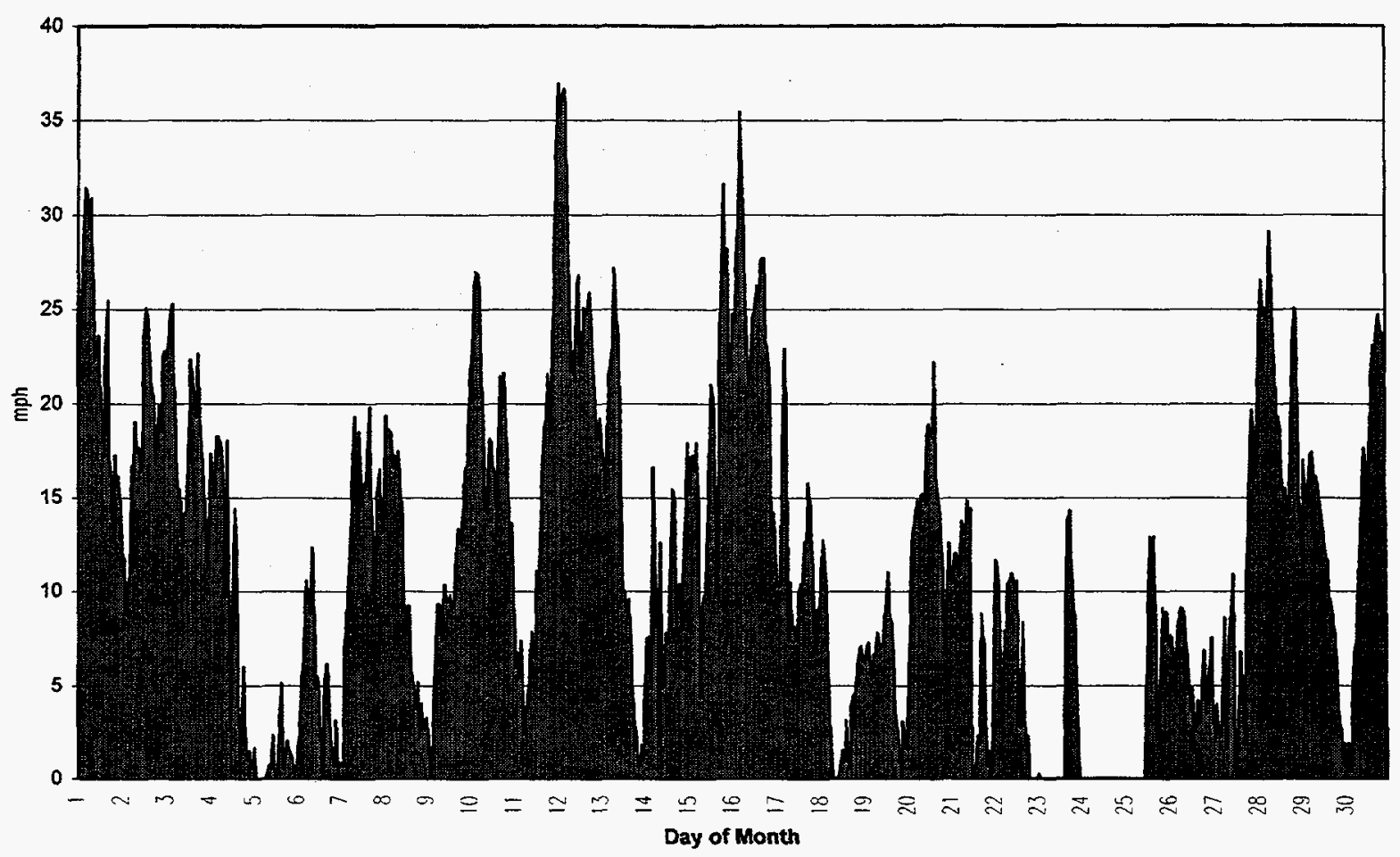

Figure C.9. Hourly wind speed at $120 \mathrm{ft} .(36.5 \mathrm{~m})$ in November 1996

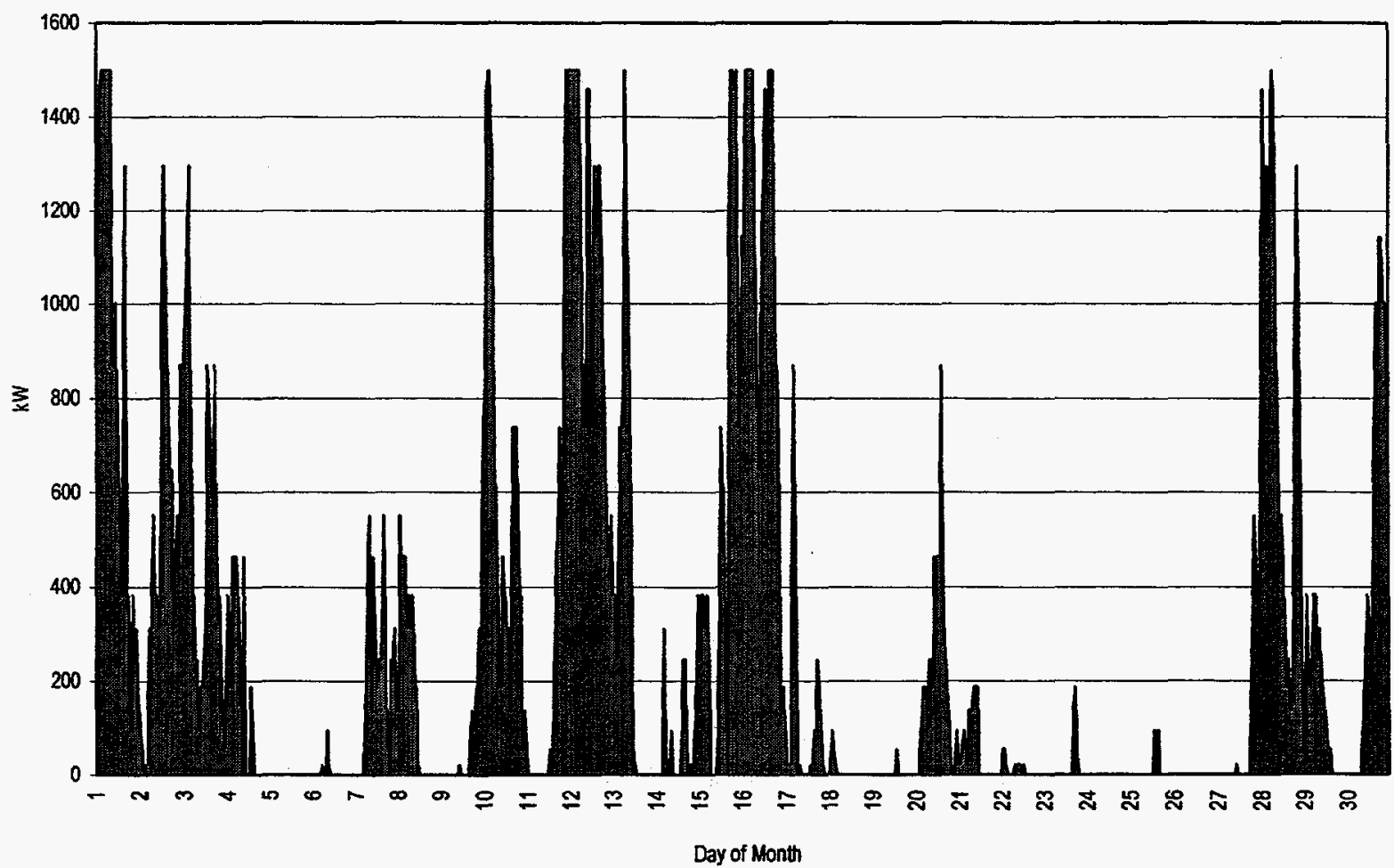

Figure C.10. Hourly 1.5-MW wind farm performance in November $1996-120 \mathrm{ft} .(36.5 \mathrm{~m})$ winds

$$
\text { C }-6
$$




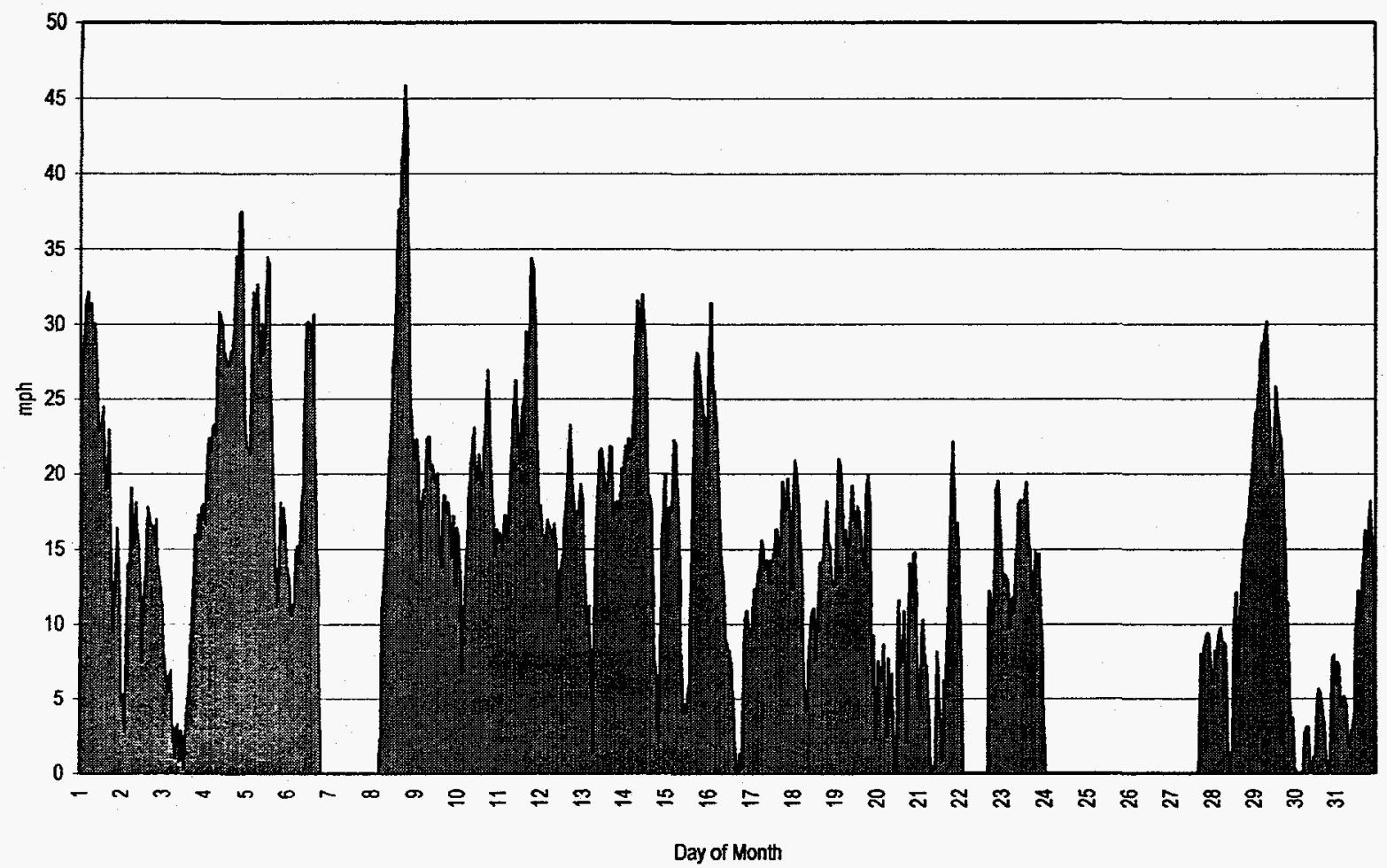

Figure C.11. Hourly wind speed at $120 \mathrm{ft} .(36.5 \mathrm{~m})$ in December 1996

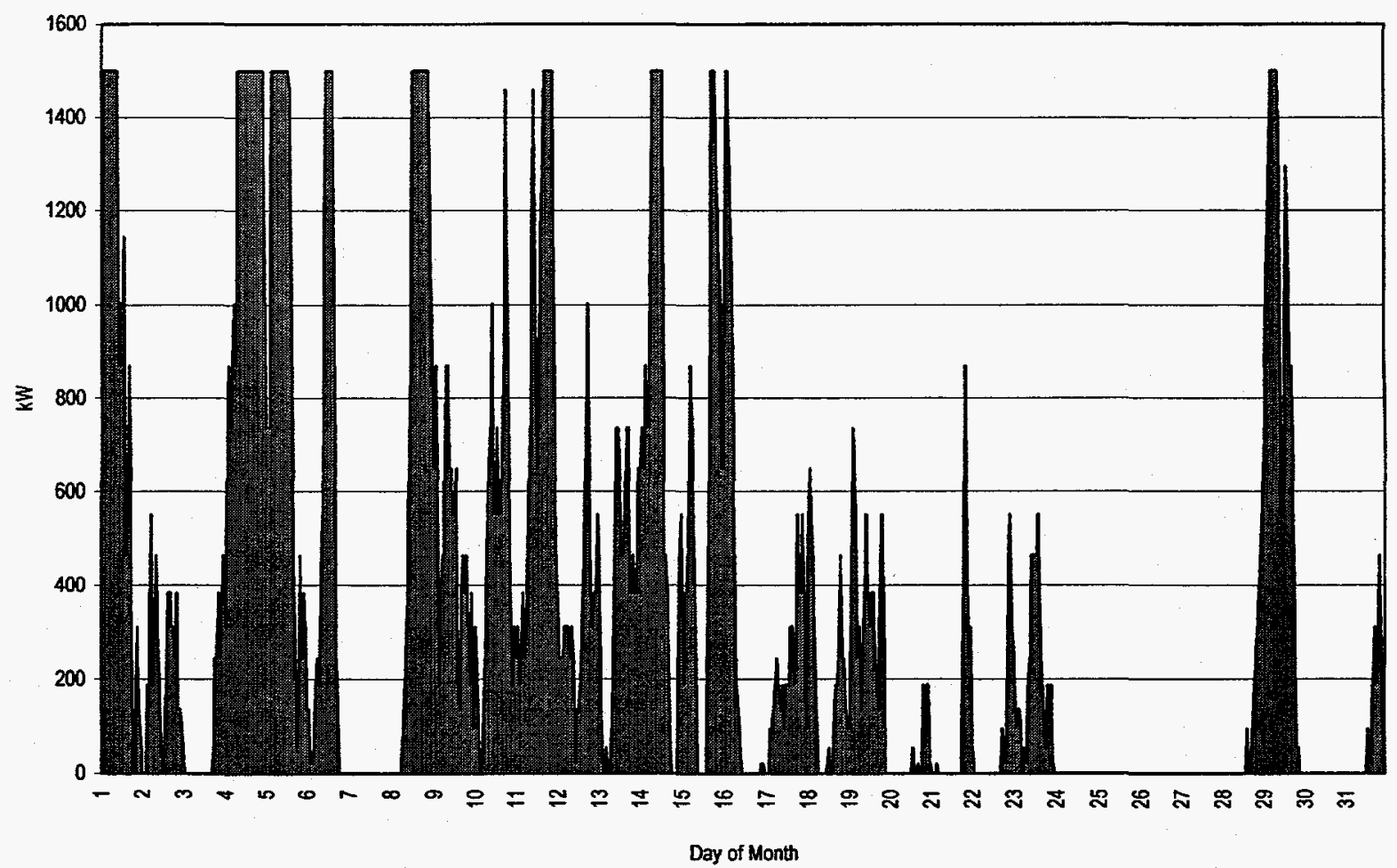

Figure C.12. Hourly 1.5-MW wind farm performance in December 1996-120 ft. $(36.5 \mathrm{~m})$ winds

$$
\text { C }-7
$$




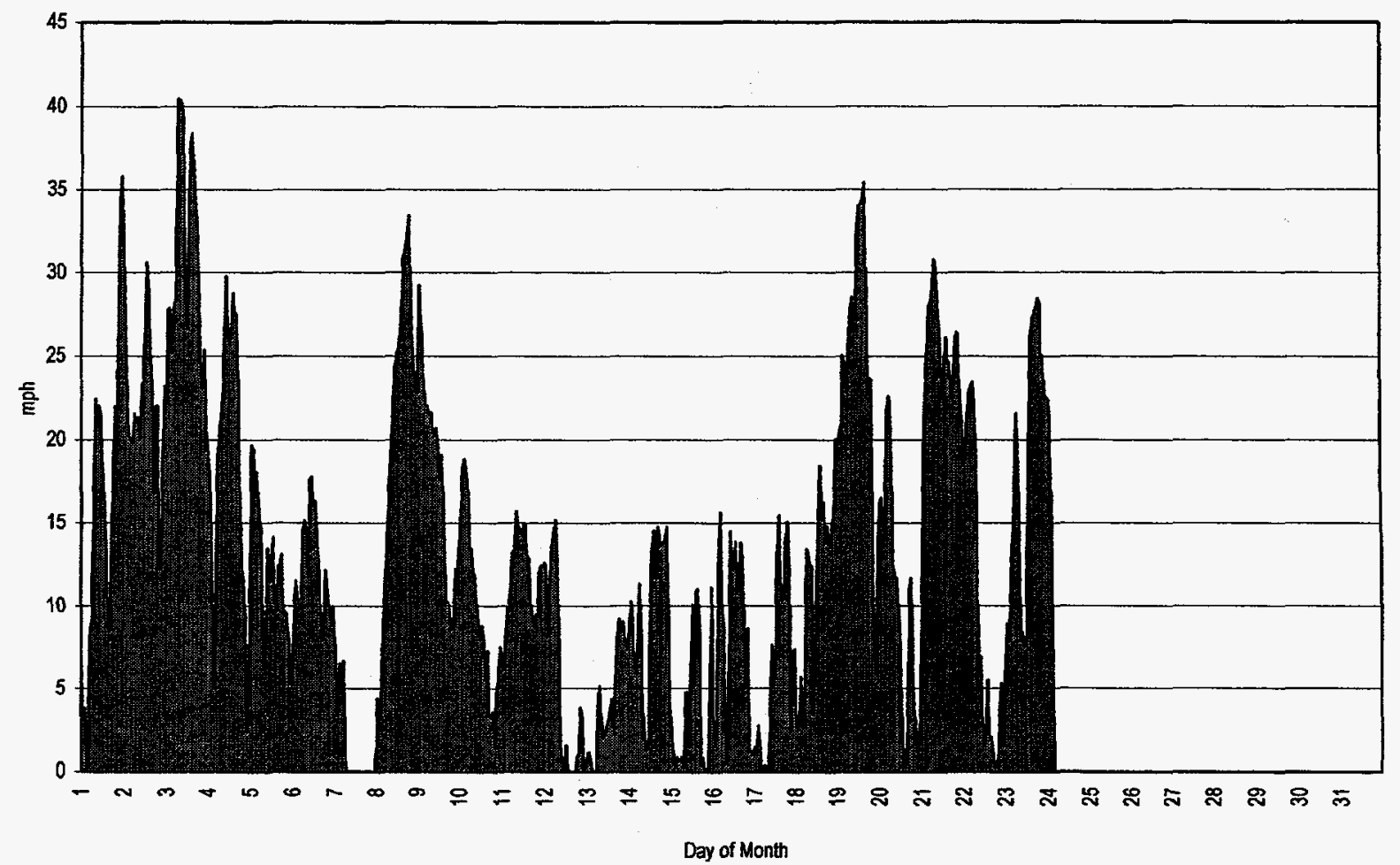

Figure C.13. Hourly wind speed at $120 \mathrm{ft} .(36.5 \mathrm{~m})$ in January 1997

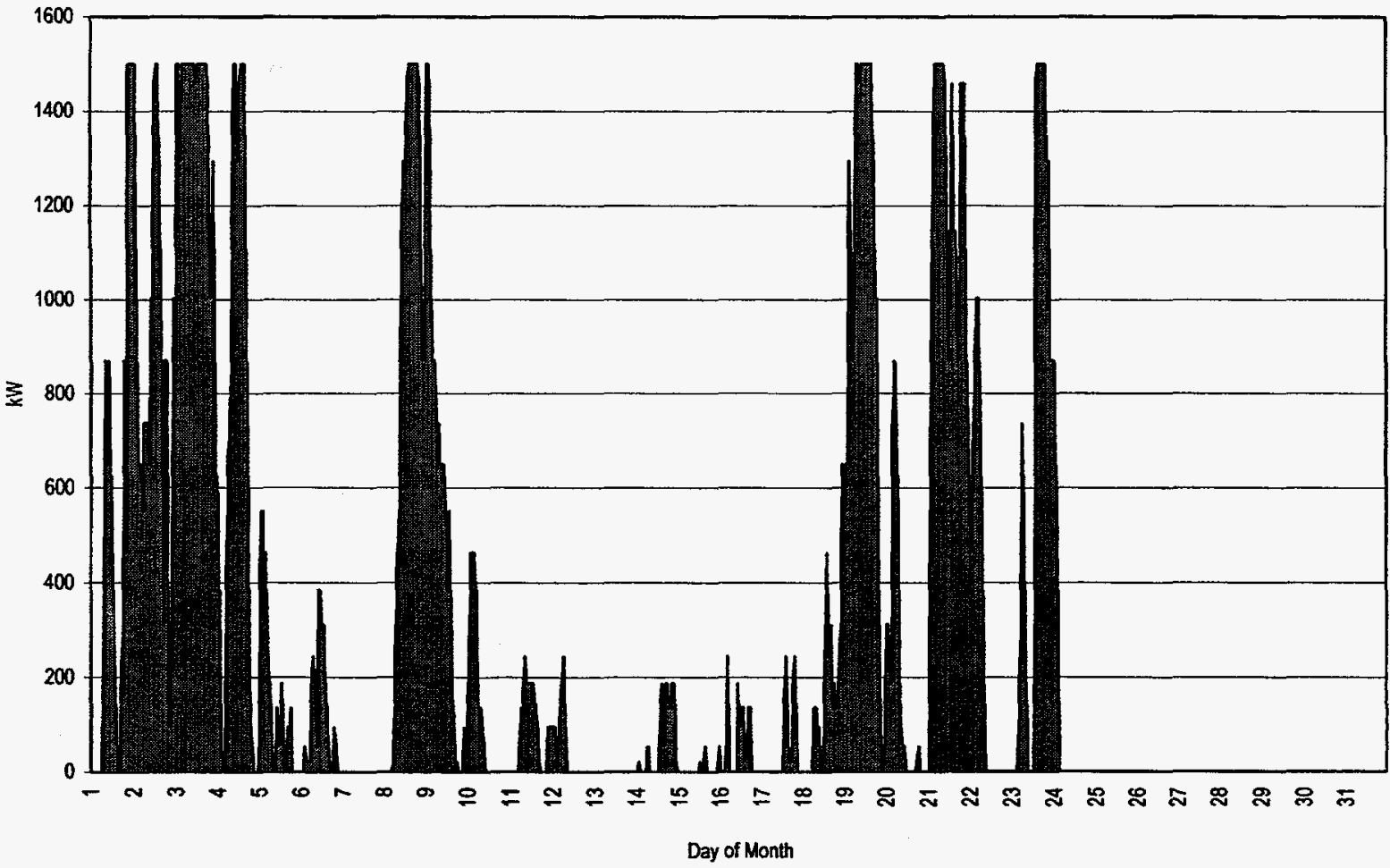

Figure C.14. Hourly 1.5-MW wind farm performance in January $1997-120 \mathrm{ft} .(36.5 \mathrm{~m})$ winds C -8 


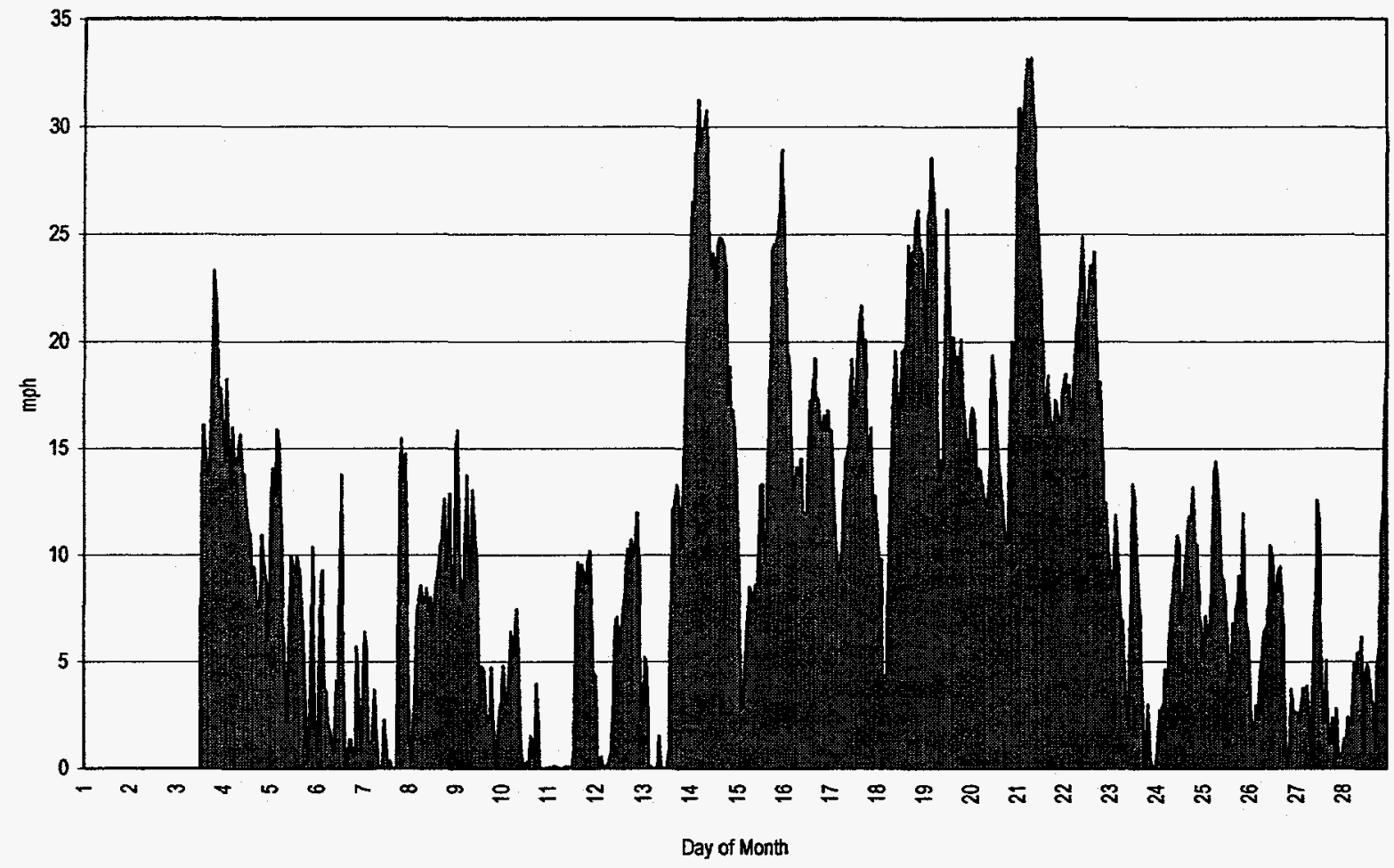

Figure C.15. Hourly wind speed at $120 \mathrm{ft} .(36.5 \mathrm{~m})$ in February 1997

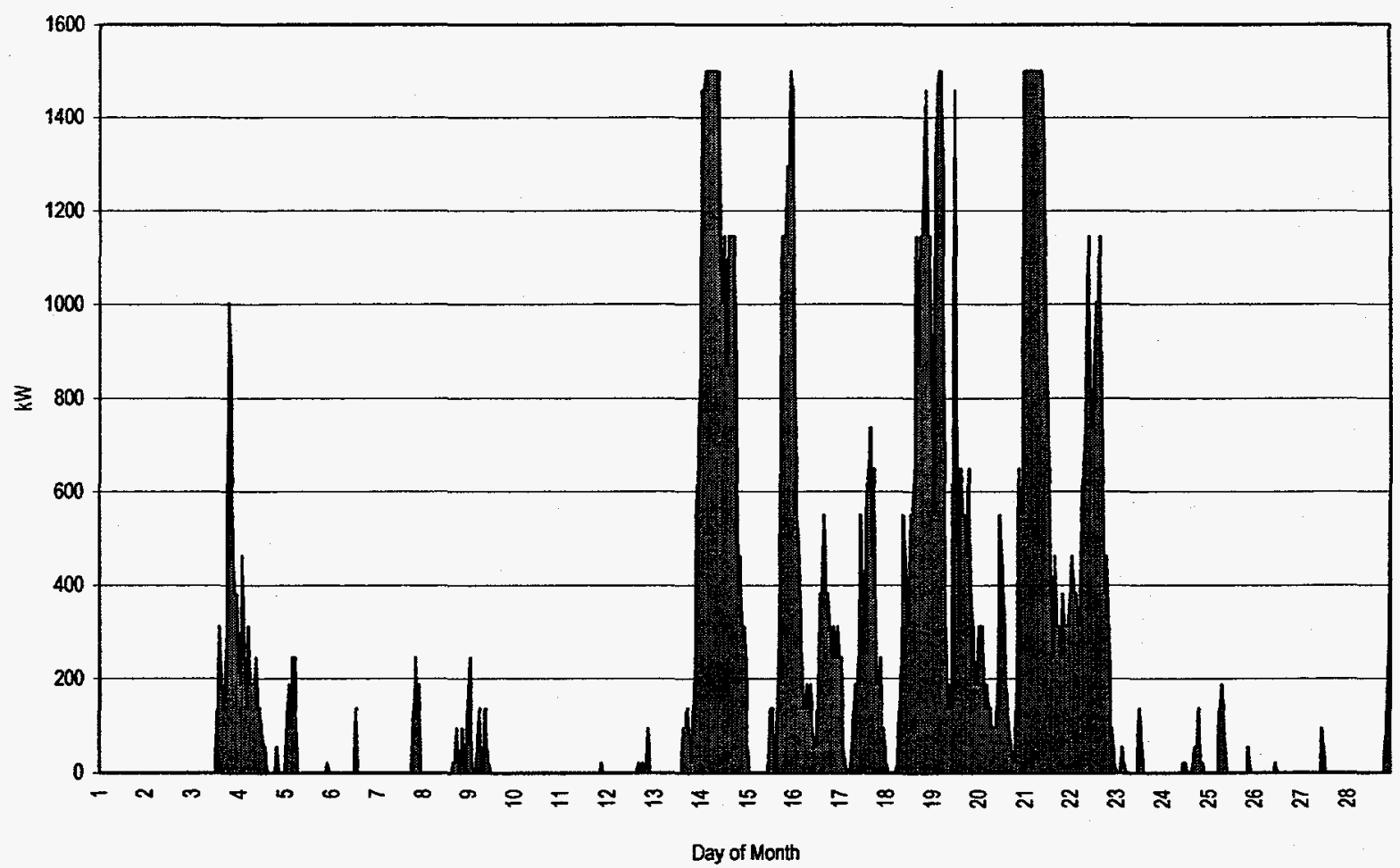

Figure C.16. Hourly 1.5-MW wind farm performance in February $1997-120 \mathrm{ft}$. (36.5 m) winds C - 9 


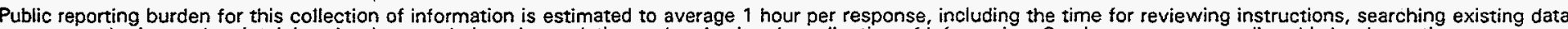

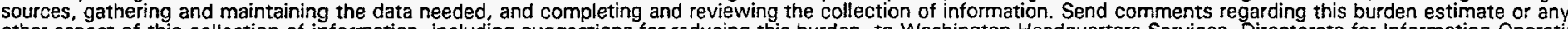

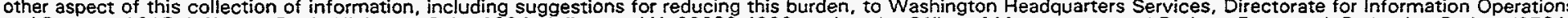

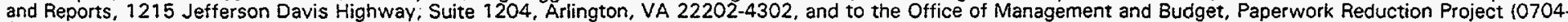
01881. Washington, DC 20503.

\begin{tabular}{|l|l|l|}
\hline 1. & $\begin{array}{l}\text { 2. REPORT DATE } \\
\text { September 1998 }\end{array}$ & $\begin{array}{l}\text { 3. REPORT TYPE AND DATES COVERED } \\
\text { Subcontractor Report }\end{array}$ \\
\hline
\end{tabular}

4. TITLE AND SUBTITLE

Integrating Wind Turbines into the Orcas Island Distribution System

5. FUNDING NUMBERS

6. AUTHOR(S)

Henry W. Zaininger

7. PERFORMING ORGANIZATION NAME(S) AND ADDRESS(ES)

Zaininger Engineering Company

8. PERFORMING ORGANIZATION

1451 Rocky Ridge Dr. \#3004

Roseville, CA 95661

C: TAT-6-16476-01

TA: WE802020

9. SPONSORING/MONITORING AGENCY NAME(S) AND ADDRESS(ES)

10. SPONSORING/MONITORING AGENCY REPORT NUMBER

National Renewable Energy Laboratory

1617 Cole Blvd.

SR-500-24792

Golden, CO 80401-3393

11. SUPPLEMENTARY NOTES

12a. DISTRIBUTION/AVAILABILITY STATEMENT National Technical Information Service

12b. DISTRIBUTION CODE

U.S. Department of Commerce

5285 Port Royal Road

Springfield, VA 22161

13. ABSTRACT (Maximum 200 words)

This research effort consists of two years of wind data collection and analysis to investigate the possibility of strategically locating a megawatt (MW) scale wind farm near the end of an Orcas Power and Light Company (OPALCO) 25-kilovolt (kV) distribution circuit to defer the need to upgrade the line to $69 \mathrm{kV}$. The results of this study support the results of previous work $i$ which another year of wind data and collection was performed. Both this study and the previous study show that adding a MWscale wind farm at the Mt. Constitution site is a feasible alternative to upgrading the OPALCO 25-kv distribution circuit to $69 \mathrm{kV}$

\begin{tabular}{|c|c|c|c|c|c|c|c|}
\hline \multirow{2}{*}{14.} & \multirow{2}{*}{\multicolumn{5}{|c|}{$\begin{array}{l}\text { SUBJECT TERMS } \\
\text { renewable energy; wind energy integration; wind energy; wind turbines; islands; } \\
\text { distribution systems and wind energy }\end{array}$}} & 15. & NUMBER OF PAGES \\
\hline & & & & & & 16. & PRICE CODE \\
\hline 17. & $\begin{array}{l}\text { SECURITY } \\
\text { CLASSIFICATION } \\
\text { OF REPORT } \\
\text { Unclassified }\end{array}$ & 18. & $\begin{array}{l}\text { SECURITY } \\
\text { CLASSIFICATION } \\
\text { OF THIS PAGE } \\
\text { Unclassified }\end{array}$ & 19. & $\begin{array}{l}\text { SECURITY } \\
\text { CLASSIFICATION } \\
\text { OF ABSTRACT } \\
\text { Unclassified }\end{array}$ & 20. & $\begin{array}{l}\text { LIMITATION OF ABSTRACT } \\
\text { UL. }\end{array}$ \\
\hline
\end{tabular}

NSN 7540-01-280-5500

Standard Form 298 (Rev. 2-8 Prescribed by ANSI Std. Z3 